PNNL-13140

\title{
A ssessment of Energy Efficiency Project Financing Alternatives for Brookhaven National Laboratory
}

D. Hunt

J. Hail

G.P. Sullivan

February 2000

Prepared for the

U.S. D epartment of Energy

$O$ ffice of Energy Efficiency and Renewable Energy

Federal Energy Mangement Program

under Contract DE-AC06-76RLO 1830 


\title{
DISCLAIMER
}

This report was prepared as an account of work sponsored by an agency of the United States Government. Neither the United States Government nor any agency thereof, nor Battelle Memorial Institute, nor any of their employees, makes any warranty, express or implied, or assumes any legal liability or responsibility for the accuracy, completeness, or usefulness of any information, apparatus, product, or process disclosed, or represents that its use would not infringe privately owned rights. Reference herein to any specific commercial product, process, or service by trade name, trademark, manufacturer, or otherwise does not necessarily constitute or imply its endorsement, recommendation, or favoring by the United States Government or any agency thereof, or Battelle Memorial Institute. The views and opinions of authors expressed herein do not necessarily state or reflect those of the United States Government or any agency thereof.

\author{
PACIFIC NORTHWEST NATIONAL LABORATORY \\ operated by \\ BATTELLE \\ for the \\ UNITED STATES DEPARTMENT OF ENERGY \\ under Contract DE-AC06-76RLO 1830
}

\author{
Printed in the United States of America \\ Available to DOE and DOE contractors from the \\ Office of Scientific and Technical Information, P.O. Box 62, Oak Ridge, TN 37831; \\ prices available from $(615) 576-8401$.
}

Available to the public from the National Technical Information Service,

U.S. Department of Commerce, 5285 Port Royal Rd., Springfield, VA 22161

This document was printed on recycled paper. 


\section{PREFACE}

The mission of the U.S. Department of Energy's Federal Energy Management Program (FEMP) is to reduce the cost of Government by advancing energy efficiency, water conservation, and the use of solar and other renewable technologies. This is accomplished by creating partnerships, leveraging resources, transferring technology, and providing training and technical guidance and assistance to agencies. Each of these activities is directly related to achieving the requirements set forth in the Energy Policy Act of 1992 and the goals that have been established in Executive Order 13123 (June 1999), as well as supporting activities that promote sound management of Federal financial and personnel resources. The Pacific Northwest National Laboratory (PNNL) supports the FEMP mission in all activity areas.

This document provides findings and recommendations that resulted from an assessment of the Brookhaven National Laboratory by a team from Pacific Northwest National Laboratory to assess the site's potential for various alternative financing options as a means to implement energyefficiency improvements. The assessment looked for life-cycle cost-effective energy-efficiency improvement opportunities, and through a series of staff interviews, evaluated the various methods by which these opportunities may be financed, while considering availability of funds, staff, and available financing options. This report summarizes the findings of the visit and the resulting recommendations. 


\section{ACKNOWLEDGEMENTS}

The authors would like to acknowledge the following staff for their assistance and insights into this report: Ed Byrne, Dave Dale, John DiNicola, , Barbara Pierce, Tony Salvo, Mike Schaeffer, Tom VanderPutten, and Lance Warren, Brookhaven National Laboratory; with a special thanks to Mark Toscano, the BNL Energy Manager. The authors would also like to thank Joe Eng, DOE Brookhaven, for his assistance. This work was funded by the U.S. Department of Energy's Federal Energy Management Program. Pacific Northwest National Laboratory is operated for the U.S. Department of Energy by Battelle Memorial Institute under Contract DE-AC06-76RLO 1830. 


\section{SUMMARY}

Since the establishment of energy reduction goals for Federal agencies as a result of the National Energy Conservation Policy Act of 1988, Federal sites have been actively seeking and implementing a wide variety of energy-efficiency measures in facilities across the Federal sector. The Federal Energy Management Program (FEMP) has funded the Pacific Northwest National Laboratory (PNNL) to perform an assessment of facilities at Brookhaven National Laboratory (BNL) to assess the site's potential for various alternative financing options as a means to implement energy-efficiency improvements. This document provides findings and recommendations of that assessment, which looked for life-cycle cost-effective energy-efficiency improvement opportunities and evaluated the various methods by which these opportunities may be financed, while considering availability of funds, staff, and available financing options. This report summarizes the findings of the visit and the resulting recommendations.

BNL is considered a large energy user, with fiscal year 1997 energy bills totaling \$20.69 million. Recently completed building energy audits for 44 buildings identified potential energy conservation measures representing an estimated total investment of almost $\$ 4.9$ million. However, the main issue of energy efficiency implementation at Federal sites tends not to be that of identifying potential cost-effective measures, but instead tends to center around identifying suitable project financing mechanisms and selecting the funding option that best satisfies a particular site's needs. Funding options considered in this report are as follows: appropriated funds as either DOE operating expense funds or line items, energy savings performance contracts, utility financing, financing through the Bonneville Power Administration, fuel and product procurements, and replacement upon failure.

Analyses aimed at identifying a project financing strategy tend to focus on strictly economic factors such as simple payback periods, economic attractiveness to potential providers, and potential financing rates (for alternatively financed projects). However, it is the site-specific factors that define project (financing) constraints that must be identified and addressed up-front prior to establishing a final energy-efficiency procurement strategy. During its visit to BNL, the project team focused its efforts on identifying these site specific factors, the most significant of which appear to be:

- Obtaining up-front/site-incurred project funding necessary to develop, procure, and manage energy efficiency projects, and

- the Lab's willingness to enter into long-term contracts, especially beyond 10 years.

The primary conclusions reached in this report are as follows:

Conclusion 1: BNL's primary energy management strategy of controlling costs through aggressive electric procurement negotiations and site-wide load management have been tremendously successful, as demonstrated by the very low electric rates paid relative to the surrounding community. BNL rightly intends to continue with this strategy.

Conclusion 2: Significant resources must be available at the site level to identify, develop, and manage energy-efficiency projects. In the case of BNL, funding on the order of $30 \%$ of the estimated project capital investment costs are required up-front before project development efforts may begin. 
Conclusion 3: There are significant cost-effective energy-efficiency improvements available to the site, as documented in the site audits as well as through the observations made during the site visit. However, the feasibility of capturing these energy-efficiency improvements is an issue that must still be addressed by the Lab. The feasibility of alternatively financed projects can be significantly impacted by factors other than the total investment potential, energy savings potential, etc. The most significant factor at BNL appears to be that of limiting the contract term to 10 years, which results in reducing the audit identified investment potential from $\$ 4.9$ million down to $\$ 2.0$ million. Note that when other site-specific factors are applied, the estimated investment potential for a project financed over 10 years is further reduced to a range of $\$ 650 \mathrm{~K}$ to $\$ 900 \mathrm{~K}$ which, in turn, greatly reduces the economic attractiveness to potential service providers.

What this report does not do is suggest a final energy-efficiency procurement strategy for BNL. Instead, it highlights the issues needing to be addressed by the Lab when considering all the available financing options, and makes a series of recommendations for how the Lab can develop a final energy-efficiency procurement strategy. These recommendations are summarized as follows:

- resolve the issue of staff funding to cover project development costs, as well as address the other site issues such as contract terms and coordination with the union staff

- $\quad$ use site funds to implement low/no cost energy conservation measures identified in the building audits

- discuss with the servicing utility the availability of energy-efficiency project financing

- consider the installation of geothermal heat pumps via the DOE technology-specific contract

- determine which, if any, of the available alternative financing methods best suit the Lab's needs

- contact Bill Klebous of the DOE Philadelphia Regional Office to obtain information on the DOE FEMP program that can support the site.

While this report focuses on a particular site, some of the conclusions presented are likely not unique to Brookhaven National Laboratory. In particular, the (in)ability of sites to finance project development activities inclusive of project identification, development of procurement documents (requests for proposals and statements of work), review of contractor submittals, construction supervision/oversight, and overall management and coordination of site support activities, needs to be understood by FEMP and its representatives. It is possible that, with a greater understanding of this issue, FEMP may wish to look into working with the agencies to help identify ways to assist the sites in identifying and obtaining funds to cover project development costs. It is also recommended to FEMP that the identification and resolution of site-specific issues such as union concerns and contract terms be addressed up-front as a part of any site assistance efforts. 


\section{CONTENTS}

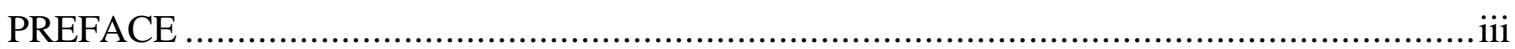

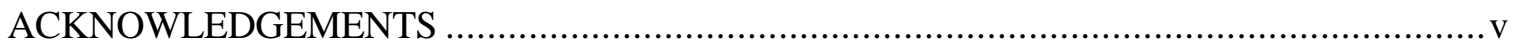

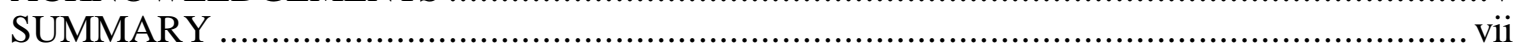

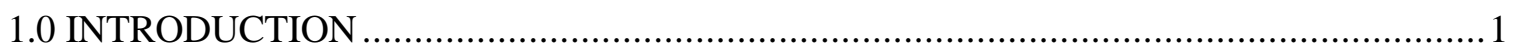

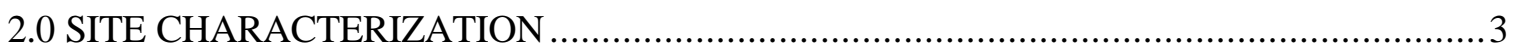

3.0 PROJECT FUNDING AND PROCUREMENT ALTERNATIVES …...............................5

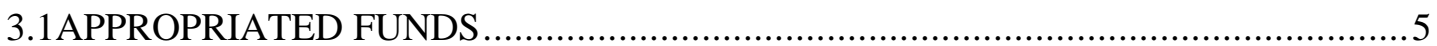

3.2 ENERGY SAVINGS PERFORMANCE CONTRACTS (ESPC) ...............................

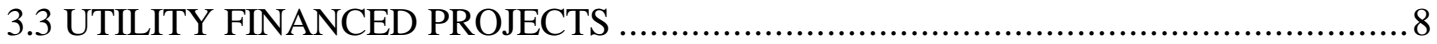

3.4 BONNEVILLE POWER ADMINISTRATION (BPA) ……….................................

3.5 FUEL AND PRODUCT PROCUREMENT ALTERNATIVES .................................... 11

3.5.1 Electric Utility Procurement.............................................................................. 11

3.5.2 Buying Energy-Efficient Products .................................................................. 11

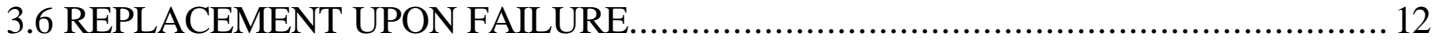

4.0 TECHNOLOGY OPPORTUNITIES/POTENTIAL ......................................................... 13

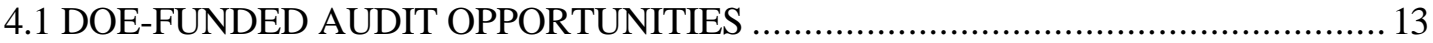

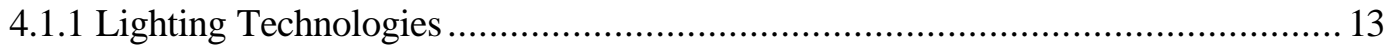

4.1.2 Heating, Ventilation and Air Conditioning (HVAC) Equipment............................ 14

4.1.3 HVAC Controls ................................................................................... 15

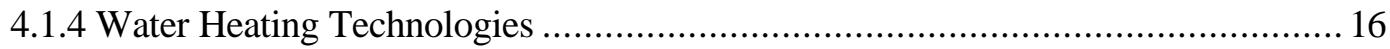

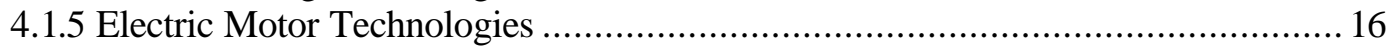

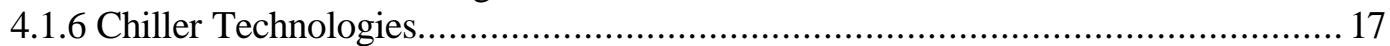

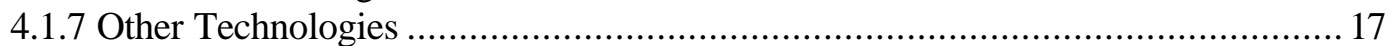

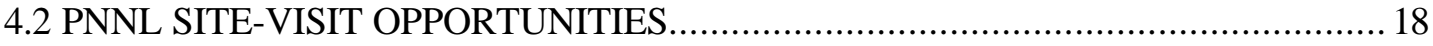

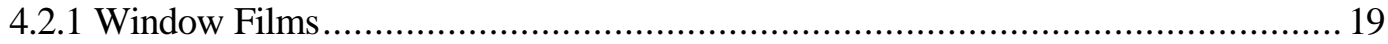

4.2.2 Recover Waste Heat from Boiler Blowdown .................................................... 19

4.2.3 Ground-Source Heat Pump Systems ……………......................................... 19

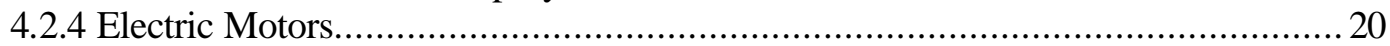

4.2.5 Central Compressed Air System............................................................. 21

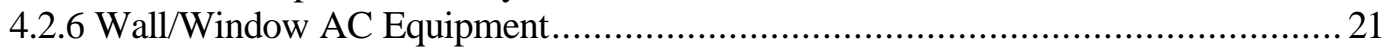

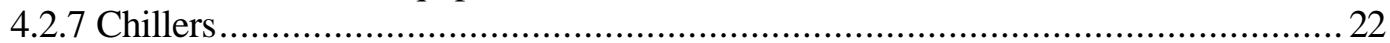

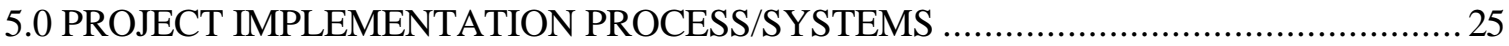

5.1 PROJECT SERVICE PROVIDERS AND STAKEHOLDERS ……………...............2

5.1.1 BNL Project Service Providers and Stakeholders............................................. 25

5.1.2 Potential External Project Service Providers.................................................... 25

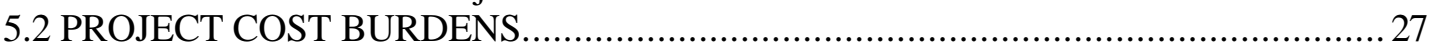

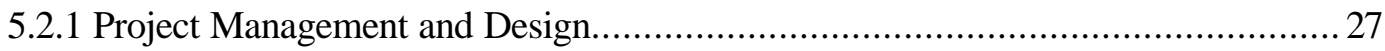

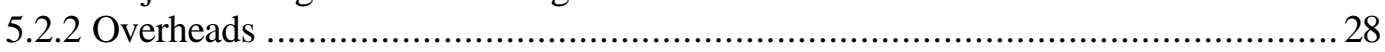

5.3 ENERGY COSTS AND ALLOCATIONS........................................................ 30

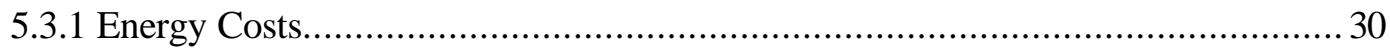

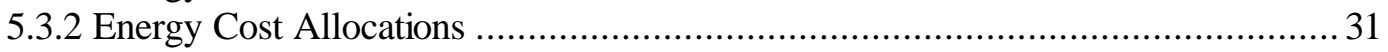

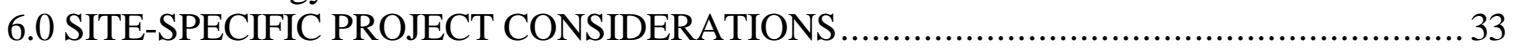

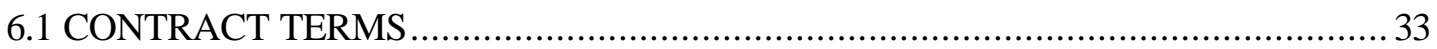

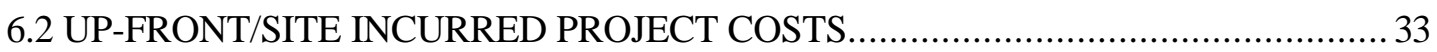

6.3 UNION CONSIDERATIONS .................................................................. 34

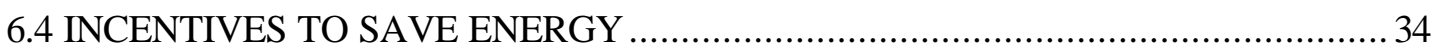


6.5 UNIQUE ELECTRIC UTILITY ARRANGEMENT

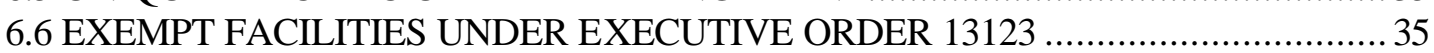

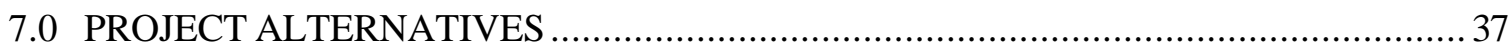

7.1 SUMMARY OF ENERGY AUDIT RECOMMENDATIONS................................... 37

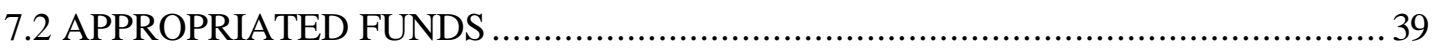

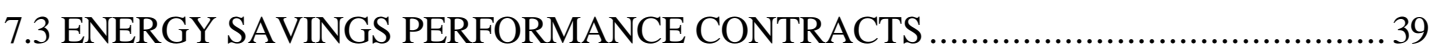

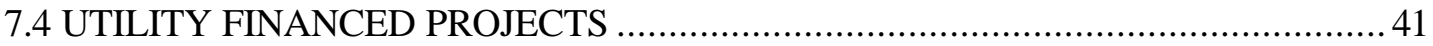

7.5 BONNEVILLE POWER ADMINISTRATION ............................................ 41

8.0 RECOMMENDATIONS FOR ENERGY-EFFICIENCY PROCUREMENT STRATEGY .. 43

9.0 REFERENCES

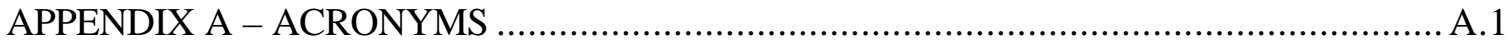

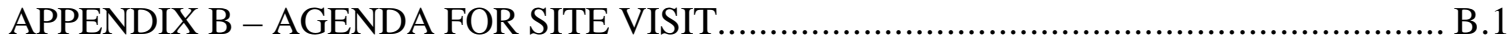

APPENDIX C - BROOKHAVEN NATIONAL LABORATORY SITE MAP ..................... C.1

APPENDIX D - BROOKHAVEN NATIONAL LABORATORY 1997 PHYSICAL PLANT

DATA SHEET

D.1

APPENDIX E - DOE GENERAL COUNSEL MEMORANDUM ON THE THE

RELATIONSHIP OF THE ANTI-DEFICIENCY ACT TO MULTI-YEAR CONTRACTS

UNDER THE UTILITY INCENTIVE PROGRAM AUTHORIZED UNDER

SECTION 152(F) OF EPACT

E. 1

APPENDIX F - AUDIT IDENTIFIED ENERGY-EFFICIENCY PROJECT LIST................... 1

APPENDIX G - EXAMPLE CALCULATIONS FROM MOTOR MASTER …................. G.1

APPENDIX H - CONTRACTED SERVICES PER E. BYRN ….................................. H.1

APPENDIX I - "FINANCING ENERGY PROJECTS AT FEDERAL FACILITIES: A SCREENING TOOL FOR DECISION MAKING”. 


\section{FIGURES}

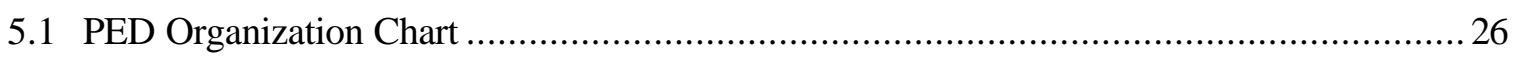

\section{TABLES}

2.1 Fiscal Year 1997 Energy Consumption and Cost Summary .......................................

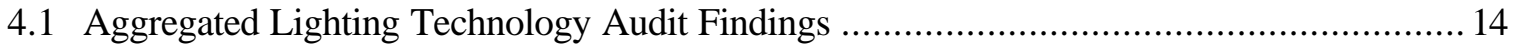

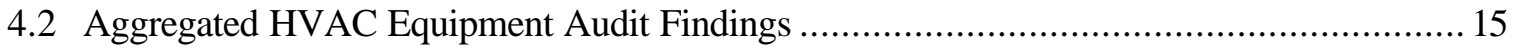

4.3 Aggregated HVAC Controls Audit Fin dings........................................................... 15

4.4 Aggregated Water Heating Technology Audit Findings .............................................. 16

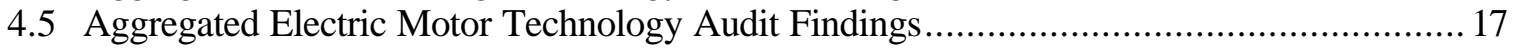

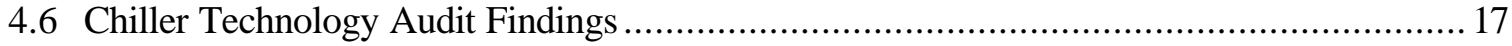

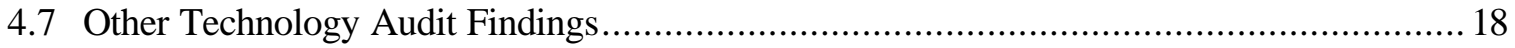

4.8 BNL Connected Chiller Loads (tons) and Refrigerant Types ..................................... 23

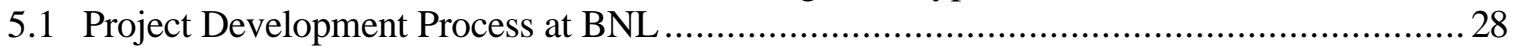

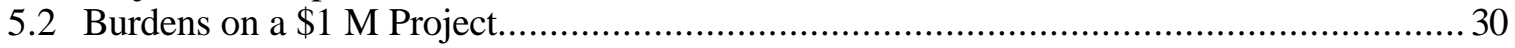

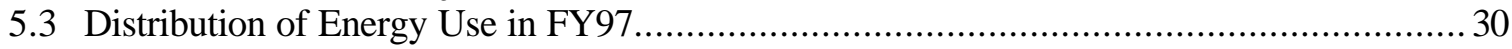

7.1 Summary of Audit Identified Potential Investments and Savings for ECMs Bundled by

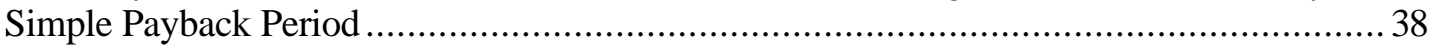

7.2 Summary of Audit Identified Potential Investments and Savings for ECMs Bundled by Simple Payback Period Adjusted with Location Factor of 1.3...................................... 38 


\subsection{INTRODUCTION}

Energy reduction goals for Federal agencies were first established in the National Energy Conservation Policy Act of 1988, and directed 10\% reduction in facility energy use based on a 1985 baseline. Since that time, Federal sites have been actively seeking and implementing a wide variety of energy-efficiency measures in facilities across the Federal sector. In the intervening years this energy reduction goal has been progressively increased to 20\% through legislation (Public Law 102-486, "The Energy Policy Act of 1992") and a number of Executive Orders. Executive Order 13123, "Greening the Government Through Efficient Energy Management," (signed June 3, 1999), further increased the facility energy-efficiency improvement goal from $30 \%$ in 2005 to $35 \%$ by 2010 relative to the 1985 baseline.

Since 1988, Federal agencies and their sites have been aggressively striving to achieve these various goals through a number of methods such as awareness programs, operations and maintenance programs, and to a much larger degree through capital investment in new, more efficient energy-using systems. Through fiscal year 1997, most of these capital improvement investments have been financed by Federal appropriations to the agency budgets. However, since 1997, appropriated dollars available for energy-efficiency improvements have been significantly reduced and, for some agencies, eliminated entirely. While the traditional funding source of appropriations dollars has been drying up, other energy-efficiency capital investment financing alternatives have been made available to Federal sites in the forms of energy savings performance contracts and utility energy services contracts. So where agency appropriations for energyefficiency improvements have been reduced, sites seeking to implement a greater degree of energy-efficiency projects (which also work to improve the overall facility infrastructure) now actually have a greater number of funding options available to them. With all these alternatives to choose from, it is apparent that there is not a "one-size-fits-all" financing approach for Federal sites. Sites looking to implement projects must not only look at energy and cost savings issues; they must now also look at staffing resources for project implementation and long term contract administration, facility master plans, projected building repair budgets, workforce coordination, and a host of other issues to determine which project financing approach best fits their needs.

With this in mind, a team from the Pacific Northwest National Laboratory (PNNL) visited the Brookhaven National Laboratory (BNL) on Long Island New York from May 4-7, 1999, to assess the site's potential for various alternative financing options as a means to implement energyefficiency improvements. This assessment was twofold in its nature. The team looked for lifecycle cost-effective energy-efficiency improvement opportunities and through a series of staff interviews, evaluated the various methods by which these opportunities may be financed, while considering availability of funds, staff, and available financing options. This report summarizes the findings of the visit and the resulting recommendations.

The PNNL team that visited BNL was composed of John Hail, Steven Parker, Greg Sullivan, and Dave Hunt (project manager). Prior to the visit to BNL, Dave Hunt worked with Mark Toscano (BNL Energy Manager) and BNL staff involved in the energy management and project decision processes to identify critical issues. Once this process was completed, the agenda for the visit was established. A copy of the visit agenda is located in Appendix B. 


\subsection{SITE CHARACTERIZATION}

The Brookhaven National Laboratory is a multi-program Department of Energy National Laboratory that is operated by the Brookhaven Science Associates, a partnership arrangement between the Battelle Memorial Institute and The Research Foundation of the State University of New York (SUNY) on behalf of SUNY-Stony Brook. The Laboratory's mission is primarily that of basic and applied scientific research with programs in the areas of high energy particle and nuclear physics, advanced accelerator concepts, advanced scientific computing and systems analysis, molecular biology and biotechnology, and chemical, environmental, medical, and material sciences. For more information on the Laboratory, including its on the mission, organization, and facilities, visit the Lab's home page at www.bnl.gov.

Brookhaven National Laboratory is located on 5,320 acres approximately in the center of the eastern half of Long Island, New York, in Suffolk County. The Laboratory reports having a total building area of approximately 4.2 million square feet contained in 402 buildings and 379 portable structures, and includes process facilities. ${ }^{a}$ A site map is located in Appendix C. The predominate building end uses in order of total square footage are research and development, office space, service buildings, and housing. ${ }^{\mathrm{b}}$

The Laboratory also reports having spent $\$ 20.69$ million on various energy sources in fiscal year 1997. ${ }^{\mathrm{c}}$ In addition, the Laboratory reports having reduced its building energy use by $22.2 \%$ when compared to the 1985 building energy use baseline (see footnote c). Thus, the site has already achieved the fiscal year 2000 energy-efficiency improvement goal of $20 \%$ for buildings, as established in the Energy Policy Act of 1992 (Public Law 102-486). It appears that the site is well on the way to meeting the fiscal year 2005 efficiency improvement goal of $30 \%$ and the fiscal year 2010 efficiency improvement goal of 35\% recently established in Executive Order 13123. (Note that the energy improvement goals established in EPAct and the Executive Orders are at the agency, not site, level. However, many agencies have delegated these goals to the site level through agency policy and guidance.) According to site staff, these efficiency improvements were realized largely as a result of energy-efficiency projects funded by the Department of Energy's In-House Management Program (IHEM). Over the period covering fiscal years 1985 through 1995, IHEM authorized energy-efficiency project funding at BNL totaled \$31.3 million (see footnote c). However, the IHEM Program has since been disbanded at the direction of Congress, and the Department of Energy (DOE) has not received dedicated appropriations for energy-efficiency improvement projects since fiscal year 1996.

The metered process energy load at the Lab accounts for approximately $37 \%$ of the annual site energy use. This energy use is reported as being exclusively electric. Relative to a base year of 1985, the metered process energy use at the Lab has increased $37.6 \%$ on a Btu per square foot basis (see footnote c). Section 203 of Executive Order 13123 established a new goal for energy efficiency in industrial and laboratory facilities as "a reduction in energy consumption per square foot, per unit of production, or per other unit as applicable by $20 \%$ by 2005 and $25 \%$ by 2010 relative to 1990. No facilities will be exempt from these goals unless they meet new criteria for exemptions, as issued by DOE." It is not possible to compare the Lab's progress toward attaining

\footnotetext{
${ }^{\text {a } J o h n ~ D i N i c o l a, ~ B r o o k h a v e n ~ S c i e n c e ~ A s s o c i a t e s ~-~ S i t e s ~ a n d ~ F a c i l i t i e s ~ M a s t e r ~ P l a n n e r, ~ M a y ~ 5, ~ 1999, ~}$ presentation.

${ }^{b}$ Data obtained from U.S. Department of Energy database, FEMPTracks.

${ }^{c}$ Brookhaven National Laboratory Energy Management Group, "FY1997 In-House Energy Management Factbook"
} 
this particular goal for a number of reasons. The metered process data are relative to a 1985 baseline. In addition, the new goal allows for the establishment of a measure based on unit of production or other unit. And lastly, the new criteria for exemptions have not been issued by DOE.

Table 2.1 summarizes the energy use by type at the Laboratory for fiscal year 1997 (see footnote c, page 3).

TABLE 2.1. Fiscal Year 1997 Energy Consumption and Cost Summary

\begin{tabular}{|l|c|c|l|}
\hline Energy Type & $\begin{array}{l}\text { FY 1997 } \\
\text { Consumption }\end{array}$ & FY 1997 Cost (\$) & $\begin{array}{l}\text { FY 1997 Energy } \\
\text { Unit Cost }\end{array}$ \\
\hline Electric & $256,499.7 \mathrm{MWh}$ & $17,759,485$ & $\begin{array}{l}\$ 0.069 / \mathrm{kWh}= \\
\$ 20.23 / \mathrm{MMBtu}\end{array}$ \\
\hline Natural Gas & $34,135 \mathrm{Mcf}$ & 106,515 & $\$ 3.12 / \mathrm{MMBtu}$ \\
\hline $\begin{array}{c}\text { Residual Oil } \quad \text { No. 6 } \\
-\quad \begin{array}{l}\text { Alternate liquid } \\
\text { fuels (ALF) }\end{array}\end{array}$ & $\begin{array}{c}3,744,466 \text { gallons } \\
549 \text { gallons }\end{array}$ & $\mathrm{NA}$ & \\
Total (\#6 + ALF) & & $\mathrm{NA}$ & \\
\hline Distillate Oil & 177,381 gallons & $2,220,496$ & $\$ 4.27 / \mathrm{MMBtu}$ \\
\hline $\begin{array}{l}\text { Liquid Propane Gas } \\
\text { (LPG) }\end{array}$ & 53,161 gallons & NA & $\$ 3.13 / \mathrm{MMBtu}$ \\
\hline
\end{tabular}

Electricity is purchased from the New York Power Authority (NYPA) at a rate significantly below the going rate provided by the Long Island Power Authority, the local franchised electric utility. NYPA makes low cost electricity available to several groups of customers throughout the state of New York. Electricity is delivered to the site at $69 \mathrm{kV}$ and distributed underground throughout the site at $13.8 \mathrm{kV}$ and $2.4 \mathrm{kV}$. The site has a very active load management program and in fiscal year 1997 maintained an electric load factor in the range of 69 to 85\%." (page 6-11 of Factbook - see footnote a)

The primary source of building heat is steam generated at the Central Steam Facility, which distributes steam to more than 60 buildings with a total area of over 2.8 million square feet (page 7-1 of Factbook - see footnote a). There are more than 12,000 tons of cooling capacity throughout the site with a 4,830-ton central chilled water facility (CCWF) providing chilled water, as well as compressed air, to nine of the Lab's buildings (footnote a, page 8-1). In an effort to manage cooling electric demand loads, a 3.2-million-gallon chilled water storage tank was constructed at the CCWF.

A summary of the Lab's physical plant data is in Appendix D.

\footnotetext{
${ }^{a}$ Brookhaven National Laboratory Energy Management Group, “FY1997 In-House Energy Management Factbook"
} 


\subsection{PROJECT FUNDING AND PROCUREMENT ALTERNATIVES}

There are a number of energy-efficiency financing and procurement alternatives available to BNL as follows:

3.1 Appropriated Funds

3.2 Energy Savings Performance Contracts (ESPC)

3.3 Utility Financed Projects

3.4 Bonneville Power Administration (BPA)

3.5 Fuel and Product Procurement Alternatives

3.6 Replacement upon Failure.

This section presents a brief summary of these alternatives. Many of these options will be considered later in this report as possible components of a site-wide energy-efficiency strategy.

\subsection{APPROPRIATED FUNDS}

The primary source of most funds for BNL and all energy projects to date are Congressional appropriations that flow to BNL either as DOE operating expense funds or as Line Items. Operating funds flow through DOE programs at HQ and the Chicago Regional Office (CRO) to BNL for a wide variety of specific activities for R\&D and for limited facility management activities including energy efficiency.

General Plant Projects (GPPs) and Miscellaneous Capital Work Orders (MCWOs) are currently funded by DOE operating funds rather than Line Item funds. GPPs cover facility and equipment projects between $\$ 500 \mathrm{~K}$ and $\$ 5 \mathrm{M}$ and MCWOs cover project bundles that are less than $\$ 500 \mathrm{~K}$. These funds flow to BNL from several sources including the Office of Field Integration (FI, formerly the Office of Facility Management (FM)) and the Office of Science (SC, formerly the Office of Energy Research (ER)). FI typically funds projects for general purpose facilities and the major R\&D offices, such as SC, fund projects for facilities dedicated to them.

Line Items fund capital projects that are larger than $\$ 5 \mathrm{M}$ for $\mathrm{R} \& \mathrm{D}$ or facilities. Line Items have not been used for energy-efficiency projects, although that remains an option.

As noted in Section 2, the HQ office of In House Energy Management (IHEM) funded \$31M of projects at BNL from 1985 through 1995. It is not clear what kind of appropriation originated the IHEM funds, but the funds were non-lapsing and under the direct management of IHEM staff at HQ and the Field Offices. Nationwide, IHEM's unspent funds were typically returned to IHEM to fund additional projects. In the mid-1990s, new appropriations ended for IHEM. In FY 1998, IHEM consolidated its remaining unspent funds from the sites and reissued the funds through a competitive proposal process. During this same time period, DOE moved the IHEM Program and five staff from Facilities Management (FM-20) to the Federal Energy Management Program (FEMP) and renamed it the Departmental Energy Management Team (DEMT). DEMT is seeking to re-establish $\$ 5 \mathrm{M}$ of Congressional appropriations for FY $2001^{\mathrm{a}}$

Most of BNL's facility management activities - except for design/construction services - draw on appropriated operations/expense funds indirectly by charging the $R \& D$ programs that receive the appropriations. The charge methods are primarily 1) a space charge-back (rent), 2) a utility

\footnotetext{
${ }^{a}$ Email message, Vic Petrolati, Briefing to Deputy Secretary on Energy Management, of Friday, July 30, 1999 4:57 a.m.
} 
charge-back for electricity and chilled water, and 3) percent-fees overhead adders on labor and materials provided to BNL organizations. The design/construction services are charged direct to the appropriated funds during the pre-design, design, and construction phases of each project.

Significant interaction occurs between $\mathrm{HQ}, \mathrm{CRO}$, and BNL to prioritize potential projects regardless of being Line Items, GPPs, or MCWOs. BNL maintains a Project Planning, Prioritization, Budgeting Process (3PBP) to call for project proposals, prioritize the projects, and assign projects to the appropriate or possible funding source(s) including BNL internal funds. The 3PBP involves BNL senior management (Level 1) and several Planning Teams that each focus on a technical system, such as chilled water or steam. BNL ranks each project using the Risk Prioritization Matrix (RPM) and Capital Asset Management Process (CAMP) that are in use by other DOE laboratories. Each project also receives a Management Score (a bin or grouping scheme). (For additional information, see EP-MGMT-900, Planning Teams at

\section{http://epweb.pe.bnl.gov/Ep_Procedures/management.htm ).}

Although energy efficiency and/or economic paybacks earn points in the RPM and CAMP system, energy savings alone has not driven a project above the funding cutoffs. Energyefficiency projects must compete for funding against site infrastructure needs that are highpriority for personnel safety, environmental protection, and R\&D support. In the RPM system, a payback of 3 years scores 100 points, but the projects currently in Bin 1 have scores of 500 to 600 points. Given the lack of FEMP DEMT funds and the stiff competition for other appropriated funds at BNL, funds for energy projects seem very unlikely. DOE and laboratory staff nationwide commonly accept this situation.

The primary advantages of using appropriated funds are:

- $\quad$ All achieved energy and operations and maintenance (O\&M) related savings remain at BNL rather than being shared with an ESPC contractor or the US Treasury.

- Site staff are familiar with the procurement methods used with operating and Line Item appropriations.

- The project cycle is much shorter because funding typically ends with the completion of the construction phase, and the turn-over of the project to O\&M programs.

The primary disadvantages of using appropriated funds are:

- Energy-efficiency projects must compete for funding against other high-priority site infrastructure needs for personnel safety, environmental protection, and R\&D support.

- Programming of funds for larger projects may take several years, resulting in lost opportunity cost savings resulting from energy-efficiency measures.

\subsection{ENERGY SAVINGS PERFORMANCE CONTRACTS (ESPC)}

ESPCs are a form of alternative project financing whereby a Federal site enters into a contract with an energy services company, which in turn provides all the up-front project capital funding (materials and installation). These costs can include identification of building energy requirements and efficiency opportunities, and the design, acquisition, installation, operation and maintenance of the new energy- efficient equipment. In exchange, the contractor receives a share of the cost savings resulting from these improvements for the duration of the contract 
period, which may be up to 25 years. Key to the ESPC is that the resulting cost savings to the site must exceed the payments made to the contractor for each contract year, and that the energy (and cost) savings must be verified annually for the entire contract period. ${ }^{\text {a }} 42$ USC 8287 establishes authority for Federal sites to enter into EPSCs.

There are several ESPC vehicles available to BNL:

- Site-Specific ESPC: This is the ESPC method whereby the site develops, awards, and manages the ESPC contract in its entirety.

- $\quad$ DOE FEMP Regional Super-ESPCs: To simplify the ESPC process, Super-ESPCs have been developed and awarded by DOE FEMP. In short, a Super-ESPC is an Indefinite Delivery-Indefinite Quantity (IDIQ) contract that has been competitively awarded by DOE to several energy services companies for specified geographic areas. Federal sites are able to negotiate and award ESPCs (i.e., place delivery orders against the IDIQ) with the pre-selected energy services contractors (ESCOs) without having to start the contracting process from scratch (Carroll 1999). Note that the U.S. Army Corps of Engineers also makes available to Federal sites a similar IDIQ contract.

- $\quad$ DOE FEMP Technology-Specific Super-ESPCs: Technology-specific Super-ESPCs are similar to the regional Super-ESPCs in that they are IDIQ contracts that have been competitively awarded by DOE to selected contractors. Technology-specific SuperESPCs differ from the regional contracts in that each contract is effective nationwide. Also, while a full range of efficiency measures may be implemented under a technologyspecific delivery order, a minimum portion of the capital investment costs, typically $30 \%$, must be for the purchase and installation of the IDIQ's subject technology.

The primary advantages of ESPCs are:

- The site obtains a significant amount of capital funding that is not likely from traditional funding sources. However, the site must repay the capital and financing costs to the contractor over the contract period.

- The energy and cost savings are guaranteed by the energy services company (ESCO) who must provide a minimum level of annual measurement and verification. Note that measurement and verification is to be accomplished by the application of agreed upon procedures as established in "Measurement and Verification (M\&V) Guideline for Federal Energy Projects" (DOE/GO-10096-248, February, 1996). The site and the ESCO must still agree on $\mathrm{M} \& \mathrm{~V}$ strategies deemed appropriate for installed conservation measures taking into account factors such as cost and level of accuracy required.

- The contractor typically performs operation and maintenance of installed equipment to ensure energy savings are realized.

- Contractors usually have the specialized expertise.

The primary disadvantages of ESPCs are:

- Significant site technical and contracting resources are required to implement ESPCs.

\footnotetext{
a FEMP Program Overview, “ Energy Savings Performance Contracting.” August 1997.
} 
- Achieved savings must be dedicated to paying capital and financing cost.

- The contract must be managed for the duration of the term up to 25 years because of the annual measurement and verification requirements.

- Over the contract term it may be necessary to renegotiate terms because of changes in site/building missions, building use patterns, and even utility rates. ESPCs are "longterm" contracts, sometimes as long as 25 years. It is highly likely that significant changes in energy use patterns and energy costs may result in the need to renegotiation of the contract savings and payments.

More information on ESPCs and Super-ESPCs is available from the FEMP home page at www.eren.doe.gov/femp

\subsection{UTILITY FINANCED PROJECTS}

Under the authority provided in 42 USC 8256 , Federal agencies are encouraged to participate in utility incentive programs including those offering energy project financing. Utility financed efficiency projects are similar to ESPCs in many ways, most importantly in that the capital to purchase and install new energy- efficient equipment is provided by a private sector entity (the utility) and repaid, along with financing expenses, over the term of the agreement. Utility financed energy-efficiency projects:

- $\quad$ are limited to 10-year terms

- $\quad$ make use of an existing relationship with a servicing utility

- do not require a performance guarantee, but this provision may be negotiated into the final agreement

- may have provisions for operations and maintenance negotiated into the final agreement.

The primary advantages of utility financing of energy-efficiency projects are:

- No up-front capital material and labor costs. However, the site must repay the capital costs and financing costs to the contractor over the contract period.

- Many utilities are eager to work with current customers in an effort to promote customer loyalty in preparation for the deregulated electric market.

- $\quad$ These may be sole-source agreements with the servicing utility.

- The site has control over design and construction award.

- Long-standing relationships between the site and the utility may facilitate project identification and negotiation.

The primary disadvantages of utility financing of energy-efficiency projects are:

- Not all utilities offer financing for energy-efficiency projects. 
- Savings are not guaranteed unless this provision is negotiated into the agreement. However, sites not interested in savings guarantees and the corresponding annual measurement and verification requirements will find this beneficial because total costs will be reduced.

A recent memorandum (June 22, 1999) from Mr. Mark S. Schwartz (DOE Deputy General Council for Energy Policy) to Ms. Shelley N. Fidler (Acting Director - Federal Energy Management Program) concluded that DOE sites may enter into energy and water conservation efficiency contracts with contract terms of up to 10 years and an exemption from the AntiDeficiency Act. The memorandum went on to further define the "requirements for 'qualified" DSM (demand side management) and ECM (energy conservation measure) contracts" as follows:

(1) That the primary purpose of an ECM or DSM contract under section 152(f) must be to reduce the cost or use of energy and water and achieving greater energy efficiency [for example, DOE could not construct an entire new building to achieve or facilitate a programmatic objective under the guise of an ECM or DSM contract under section 152(f)]

(2) That the general construction, training courses, and the purchase of supplies or equipment not directly related to an ECM or DSM is not permissible under section 152(f) of EPACT

(3) That energy or water savings must be sufficient to pay all costs under a DSM or ECM contract

(4) That ECMs or DSMs will not normally be used unless the new overall energy or water cost reduction can be demonstrated and verified."a

For the year or so preceding the issuance of this finding, there was a moratorium in place across DOE prohibiting sites from entering into these types of agreements. With this moratorium now lifted, BNL is now again able to pursue such services with NYPA and/or Long Island Power Authority (LIPA). A copy of this memorandum is in Appendix E.

\subsection{BONNEVILLE POWER ADMINISTRATION (BPA)}

The BPA is a DOE organization that is best known for selling low-cost electric power primarily in the pacific northwestern region of the United States. It is also a part of BPA's mission to promote the efficient use of energy, and it is under this charter that the BPA makes project financing and project management and technical services available to Federal sites. The typical steps involved in a BPA financed energy-efficiency project at a Federal site are summarized below:

1. Federal agency orders BPA to obtain market information from prospective financiers

\footnotetext{
${ }^{a}$ Memorandum from Mr. Mark S. Schwartz (DOE Deputy General Council for Energy Policy) to Ms. Shelley N. Fidler (Acting Director - Federal Energy Management Program), June 22, 1999.

${ }^{\mathrm{b}}$ Briefing slides by Tim Scanlon, BPA, used in March 10, 1999, "Using BPA to Facilitate Private Source Project Financing"
} 
2. BPA requests information on rates, terms, expenses, and contract provisions from prospective financiers

3. BPA compares financing proposals and identifies the most responsive proposal(s) to the agency

4. Agency orders BPA to obtain binding proposal from preferred financier

5. BPA secures binding commitment and negotiates funding agreement with the financier

6. Agency orders BPA to execute funding agreement and provide funds on a specific date

7. BPA executes funding agreement with financier; BPA and agency sign assignment of payments document

8. On closing date, BPA receives funds and satisfies agency's obligations to contractors and vendors.

The primary benefits of BPA financing are:

- Financing can be obtained at rates competitive with utility financed projects.

- Financial terms are flexible and can be structured to suit site's needs.

- Site retains all resulting energy cost savings.

- Site is free to select project management and technical services (no obligation).

- Site is free to structure efficiency projects in a manner that best suits them.

The primary disadvantages of BPA financing are:

- Site must provide all project technical, contracting, management, and construction support and oversight unless these services are purchased from BPA.

- Contract terms are typically limited to a maximum of 10 to 12 years.

- While there is no minimum project cost, financiers are generally interested in projects of around $\$ 500,000$ or more. Note that BPA can aggregate projects from multiple sites to offer more attractive packages to prospective financiers.

- BPA will not be involved in any shared savings arrangements.

- $\quad$ Site is responsible for measurement and verification (if so desired).

Contact Mr. Frank Brown at (206) 216-4231 or febrown@bpa.gov for additional information on energy-efficiency services available through BPA. 


\subsection{FUEL AND PRODUCT PROCUREMENT ALTERNATIVES}

Through the normal course of site operations, there are a many procurement activities taking place that impact energy use and energy costs. Two areas of procurement were discussed with the BNL staff in some length: electric utilities procurement and window (room) air conditioning units. These procurement activities will be discussed in greater detail below, but note that the window air conditioner procurement is discussed under the broader issue of buying energyefficient products.

\subsubsection{Electric Utility Procurement}

As noted in Section 2, the total cost paid by BNL for electricity in fiscal year 1997 was $\$ 17.8$ million out of a total site energy cost of $\$ 20.7$ million. Clearly the impact of electric rate increases and decreases will have a tremendous effect on the overall energy bill paid by BNL. Staff at BNL are keenly aware of this relationship and have been very successful in their procurement of relatively low cost electricity, as well as also establishing a site-wide electric load management program: in tandem these actions represent a tremendous success story.

BNL is located in the middle of Long Island, New York, where the servicing utility is the LIPA. However, as noted in Section 2, BNL purchases its electricity from the New York Power Authority. For the last few years BNL has had a blended average rate of $\$ 0.065$ to $\$ 0.070$ per $\mathrm{kWh}$. The Lab recently renegotiated this contract and now uses a figure of $\$ 0.060$ per $\mathrm{kWh}$, which includes transmission charges over other utilities' systems. While representatives of LIPA were not contacted during the course of this study to inquire about industrial customer rate schedules, it is our understanding that the LIPA rates are significantly above those currently being paid by the Lab (possibly up to twice as much).

The primary advantage of negotiating lower utility rates is lower electric rates translate into tangible operations costs savings that can be reapplied to support other site activities.

The primary "disadvantage" of negotiating lower utility rates is that lower electric rates reduce the cost effectiveness of potential energy conservation measures. As a result, many of these efficiency measures will not be implemented and site energy savings will not be realized. However, the issue to be considered is that of net benefit to the site. In the case of BNL these lower electric rates allow for increased electric use in direct support of core mission activities, with this increased usage being offset by the lower per unit rates.

\subsubsection{Buying Energy-Efficient Products}

Section 403(b)(1) of Executive Order 13123 states: "Agencies shall select, where life-cycle costeffective, ENERGY STAR $®$ and other energy-efficient products when acquiring energy-using products. For product groups where ENERGY STAR $®$ labels are not yet available, agencies shall select products that are in the upper $25 \%$ of energy efficiency as designated by FEMP." The FEMP Federal Procurement Challenge assists Federal agencies in purchasing energyefficient products by making available product energy-efficiency recommendations. These recommendations identify product efficiency/performance levels that satisfy the Executive Order requirements for a wide range of products including window (room) air conditioners. More information on the Federal Procurement Challenge Program can be found at

www.eren.doe.gov/femp/procurement 
The use of window air conditioning units at BNL is very noticeable while driving around the site. As noted in Section 2, the chilled water system does not currently service all the buildings on the site. While the number of window air conditioning units was not discussed, the availability of the product energy-efficiency recommendations was called to the attention of the Lab staff. There are other energy-using products across the Lab that are covered by product energy-efficiency recommendations, which should also be considered.

The advantages to using the product energy-efficiency recommendations are:

- Recommendations are easy to obtain and use.

- Minimal effort should be needed to incorporate performance levels into future procurements.

- Cost-effective energy efficiency and associated cost savings will be realized as a part of regular equipment change-outs caused by age and/or failure.

The main disadvantage of using the product energy-efficiency recommendations is that while significant energy savings can result from change-outs of products such as window air conditioners, large-scale investment is needed to realize available energy efficiency.

\subsection{REPLACEMENT UPON FAILURE}

Under this financing method, a site waits until a piece of equipment or system fails before requesting the funds to repair by replacement. Replacement is then accomplished with appropriated funds that are identified from the agency or site budget. Energy-efficiency improvement results from general technology efficiency improvements realized since the initial equipment/system installation. Note that while this approach relies on the use of appropriated funds, it is considered separate from the appropriated funding strategy because this a reactive funding approach, as compared to the proactive approach discussed in Section 5.1.

The primary benefits of this approach are:

- Up-front project and facilities support resources required are minimal compared to other strategies.

- Government retains all realized savings.

- Total project implementation time is typically very short because projects are driven by immediate/short-term needs.

The primary disadvantages of this approach are:

- Equipment failure may put mission/site activities at risk.

- Replacement is typically accomplished on a one-for-one basis, which can lead to lost efficiency upgrades/improvements opportunities.

- $\quad$ Energy and cost savings associated with efficiency upgrades are not realized until equipment failure occurs. 


\subsection{TECHNOLOGY OPPORTUNITIES/POTENTIAL}

The technology opportunities presented below are from two sources. First, detailed data was collected as part of DOE-funded audits conducted by BVH Engineers, Inc. of Bloomfield, Connecticut. These SAVEnergy audits were presented in 44 building-specific volumes; each volume is specific to a BNL building. For PNNL purposes, the data in each volume were transferred to a spreadsheet that allows for the sorting of the data by technology, building number, simple payback, or any other related parameter. Note that the energy audit data had been very recently received by BNL and was still considered to be in draft form. Thus, the recommendations had not yet been validated for accuracy of the assumptions or cost estimates.

The second group of technology opportunities was derived from PNNL staff observations and notes taken during the site visit. This group of opportunities is not quantified as with the DOEfunded audit data, rather, they are described qualitatively with the recommendation to pursue in greater detail if appropriate.

\subsection{DOE-FUNDED AUDIT OPPORTUNITIES}

Presented below are summary data of energy savings, cost savings, and payback information as collected and analyzed by BVH Engineers, Inc (BVH). PNNL staff were not able to verify all assumptions used by BVH because of the short duration of the visit. While PNNL staff have concerns over some of the assumptions (specifically, some cost hours of operation assumptions), we assume that the data collected and assumptions used are largely accurate; this assumption was validated by BNL staff.

These data were extracted from 44 individual building reports and transferred to a spreadsheet. Once in the spreadsheet, the data were separated by technology and sorted by ascending simple payback. Detailed spreadsheet printouts are presented in Appendix F. The full electronic spreadsheet is available from the PNNL project manager.

It was noted by the BNL Energy Manager (Mark Toscano) that the cost estimate data addresses only construction labor and material costs and does not include project start-up and support costs such as engineering and design, project management, internal administrative costs, and contingency funds. When these start-up and support costs are added to the estimated construction cost, the total project increases significantly. In addition, the calculated simple payback of the identified energy conservation measures increases accordingly. The various cost elements comprising the project start-up and support costs, along with their impacts on project economics, are identified and discussed in Section 5.

\subsubsection{Lighting Technologies}

The general category of lighting technology includes the following measures:

- changing lighting schedules

- installing occupancy sensors

- installing photocells

- replacing incandescent lamps with compact fluorescent lamps

- replacing inefficient exit signs with efficient signs

- replace inefficient fluorescent fixtures with T8 lamp and electronic ballast fixtures. 
The identified projects range in cost from $\$ 25$ to $\$ 212,000$. The annual cost savings per project varies from under $\$ 10$ to $\$ 26,000$. The simple payback calculations result in values ranging from 0.3 years to 15 years. Table 4.1 below presents the aggregated Lighting Technologies findings.

Data specific to the individual lighting technology projects are located in Appendix F.

TABLE 4.1 Aggregated Lighting Technology Audit Findings

\begin{tabular}{|c|c|c|c|c|c|c|}
\hline $\begin{array}{c}\text { Installed } \\
\text { Cost } \\
\mathbf{( \$ )}\end{array}$ & $\begin{array}{c}\text { Annual } \\
\text { Energy } \\
\text { Savings } \\
\mathbf{( k W h )}\end{array}$ & $\begin{array}{c}\text { Annual } \\
\text { Demand } \\
\text { Savings } \\
\mathbf{( k W )}\end{array}$ & $\begin{array}{c}\text { Annual } \\
\text { Energy } \\
\text { Cost } \\
\text { Savings } \\
\mathbf{( \$ )}\end{array}$ & $\begin{array}{c}\text { Annual } \\
\text { O\&M Cost } \\
\text { Savings (\$) }\end{array}$ & $\begin{array}{c}\text { Total } \\
\text { Annual } \\
\text { Cost } \\
\text { Savings (\$) }\end{array}$ & $\begin{array}{c}\text { Simple } \\
\text { Payback } \\
\text { (years) }\end{array}$ \\
\hline$\$ 1,301,539$ & $2,168,799$ & 403.1 & $\$ 184,406$ & $\$ 5,647$ & $\$ 190,053$ & 6.8 \\
\hline \multicolumn{7}{|l|}{ Annual energy cost savings does not take credit for demand reduction } \\
\hline
\end{tabular}

\subsubsection{Heating, Ventilation, and Air Conditioning (HVAC) Equipment}

The general category of HVAC equipment includes the following measures:

- testing/replacing faulty steam traps

- installation of ceiling fans

- install variable frequency drives (VFDs)

- installation of energy-efficient oil burner

- convert from constant volume to variable air volume (VAV)

- replacement of low efficiency HVAC equipment

- install VAV diffusers

- install high efficiency filters.

The identified projects range in cost from $\$ 500$ to $\$ 114,500$. The annual energy savings per project varies from $\$ 97$ to $\$ 26,571$. The simple payback calculations result in values ranging from 0.0 years to 25.8 years. Table 4.2 below presents the aggregated HVAC Equipment findings. Data specific to the individual HVAC equipment projects are located in Appendix F. 
TABLE 4.2 Aggregated HVAC Equipment Audit Findings

\begin{tabular}{|c|c|c|c|c|c|c|}
\hline $\begin{array}{c}\text { Installed } \\
\text { Cost } \\
(\$)\end{array}$ & $\begin{array}{c}\text { Annual } \\
\text { Energy } \\
\text { Savings } \\
\text { (MMBtu) }^{1,2}\end{array}$ & $\begin{array}{c}\text { Annual } \\
\text { Demand } \\
\text { Savings } \\
(\mathbf{k W})\end{array}$ & $\begin{array}{c}\text { Annual } \\
\text { Energy } \\
\text { Cost } \\
\text { Savings } \\
(\$)^{3} \\
\end{array}$ & $\begin{array}{c}\text { Annual } \\
\text { O\&M Cost } \\
\text { Savings (\$) }\end{array}$ & $\begin{array}{c}\text { Total } \\
\text { Annual } \\
\text { Cost } \\
\text { Savings (\$) }\end{array}$ & $\begin{array}{c}\text { Simple } \\
\text { Payback } \\
\text { (years) }\end{array}$ \\
\hline$\$ 363,670$ & 3,600 & 17.5 & $\$ 71,922$ & $\$ 0$ & $\$ 71,922$ & 5.0 \\
\hline \multicolumn{7}{|c|}{$\begin{array}{l}\text { MMBtu refers to million Btu } \\
\text { Savings include } \mathrm{kWh} \text {, fuel oil, steam, and chilled water } \\
\text { Annual energy cost savings calculation does not take cred }\end{array}$} \\
\hline
\end{tabular}

\subsubsection{HVAC Controls}

The general category of HVAC controls includes the following measures:

- changing HVAC setpoint temperatures

- installation of programmable thermostats

- reduction in supply air flow rates

- installation of steam cycle control systems

- installation of two-speed direct digital controls (DDC) control switching

- installation of boiler hot water reset control.

The identified projects range in cost from $\$ 5$ to $\$ 421,000$. The annual energy savings per project varies from $\$ 118$ to $\$ 71,709$. The simple payback calculations result in values ranging from almost immediate (changing setpoint temperatures) to 7.9 years. Table 4.3 below presents the aggregated HVAC Controls findings. Data specific to the individual HVAC controls projects are located in Appendix F.

TABLE 4.3 Aggregated HVAC Controls Audit Findings

\begin{tabular}{|c|c|c|c|c|c|c|}
\hline $\begin{array}{c}\text { Installed } \\
\text { Cost } \\
(\$)\end{array}$ & $\begin{array}{c}\text { Annual } \\
\text { Energy } \\
\text { Savings } \\
\text { (MMBtu) }{ }^{1,2}\end{array}$ & $\begin{array}{l}\text { Annual } \\
\text { Demand } \\
\text { Savings } \\
(\mathbf{k W})\end{array}$ & $\begin{array}{c}\text { Annual } \\
\text { Energy } \\
\text { Cost } \\
\text { Savings } \\
(\$)^{3}\end{array}$ & $\begin{array}{c}\text { Annual } \\
\text { O\&M Cost } \\
\text { Savings (\$) }\end{array}$ & $\begin{array}{c}\text { Total } \\
\text { Annual } \\
\text { Cost } \\
\text { Savings (\$) }\end{array}$ & $\begin{array}{c}\text { Simple } \\
\text { Payback } \\
\text { (years) }\end{array}$ \\
\hline$\$ 509,428$ & 13,434 & 26.3 & $\$ 118,381$ & $\$ 0$ & $\$ 118,381$ & 4.3 \\
\hline \multicolumn{7}{|c|}{$\begin{array}{l}\text { MMBtu refers to million Btu } \\
2 \text { Savings include } \mathrm{kWh} \text {, fuel oil, steam, and chilled water } \\
3 \text { Annual energy cost savings calculation does not take credi }\end{array}$} \\
\hline
\end{tabular}




\subsubsection{Water Heating Technologies}

The general category of water heating technologies includes the following measures:

- reduction in hot water setpoint temperatures

- installation of low-flow faucet aerators

- installation of low-flow showerheads

- installation of hot water tank insulation

- installation of solar hot water heating system.

The identified projects range in cost from $\$ 5$ to $\$ 17,626$. The annual energy savings per project varies from $\$ 3$ to $\$ 1,064$. The simple payback calculations result in values ranging from almost immediate (changing setpoint temperatures) to 20.3 years (solar hot water heating system). Table 4.4 below presents the aggregated water heating technology findings. Data specific to the individual Water Heating Technology projects are located in Appendix F.

TABLE 4.4 Aggregated Water Heating Technology Audit Findings

\begin{tabular}{|c|c|c|c|c|c|c|}
\hline $\begin{array}{l}\text { Installed } \\
\text { Cost } \\
(\$)\end{array}$ & $\begin{array}{c}\text { Annual } \\
\text { Energy } \\
\text { Savings } \\
\text { (MMBtu) }^{1,2} \\
\end{array}$ & $\begin{array}{c}\text { Annual } \\
\text { Demand } \\
\text { Savings } \\
(\mathbf{k W}) \\
\end{array}$ & $\begin{array}{c}\text { Annual } \\
\text { Energy } \\
\text { Cost } \\
\text { Savings (\$) } \\
\end{array}$ & $\begin{array}{c}\text { Annual } \\
\text { O\&M Cost } \\
\text { Savings (\$) }\end{array}$ & $\begin{array}{c}\text { Total } \\
\text { Annual } \\
\text { Cost } \\
\text { Savings }(\$) \\
\end{array}$ & $\begin{array}{c}\text { Simple } \\
\text { Payback } \\
\text { (years) }\end{array}$ \\
\hline$\$ 75,047$ & 1,793 & 0 & $\$ 9,537$ & $\$ 40$ & $\$ 9,577$ & 7.8 \\
\hline
\end{tabular}

\subsubsection{Electric Motor Technologies}

The general category of electric motor technologies includes the following measure:

- installation of high-efficiency electric motors

The identified projects range in cost from $\$ 515$ to $\$ 16,310$. The annual energy savings per project varies from $\$ 46$ to over $\$ 5,100$. The simple payback calculations result in values ranging from 0.7 years to 13.5 years. Table 4.5 below presents the aggregated electric motor technology findings. Data specific to the individual electric motor technology projects are located in Appendix F. 
TABLE 4.5 Aggregated Electric Motor Technology Audit Findings

\begin{tabular}{|c|c|c|c|c|c|c|}
\hline $\begin{array}{c}\text { Installed } \\
\text { Cost } \\
\mathbf{( \$ )}\end{array}$ & $\begin{array}{c}\text { Annual } \\
\text { Energy } \\
\text { Savings } \\
\mathbf{( k W h )}\end{array}$ & $\begin{array}{c}\text { Annual } \\
\text { Demand } \\
\text { Savings } \\
\mathbf{( k W )}\end{array}$ & $\begin{array}{c}\text { Annual } \\
\text { Energy } \\
\mathbf{C o s t} \\
\text { Savings } \\
\mathbf{( \$ )}\end{array}$ & $\begin{array}{c}\text { Annual } \\
\text { O\&M Cost } \\
\text { Savings (\$) }\end{array}$ & $\begin{array}{c}\text { Total } \\
\text { Annual } \\
\text { Cost } \\
\text { Savings (\$) }\end{array}$ & $\begin{array}{c}\text { Simple } \\
\text { Payback } \\
\text { (years) }\end{array}$ \\
\hline$\$ 56,299$ & 192,965 & 11.1 & $\$ 15,013$ & $\$ 0$ & $\$ 15,013$ & 3.8 \\
\hline
\end{tabular}

\subsubsection{Chiller Technologies}

The general category of chiller technologies includes the following measures:

- removing existing chiller and adding building to central chiller plant (Bldg. 815)

- installation of new high-efficiency absorption chiller (Bldg. 815)

- installation of new high-efficiency centrifugal chiller.

The identified projects range in cost from $\$ 206,000$ to $\$ 450,000$; note that the first two projects (adding building to central chiller plant and new absorption chiller) are for the same building and therefore are mutually exclusive. The annual energy savings per project varies from $\$ 10,000$ to over $\$ 23,471$. The simple payback calculations result in values ranging from 19.2 years to 20.6 years. Table 4.6 below presents the aggregated chiller technology findings; the mutually exclusive project with the lower payback was included. Data specific to the individual chiller technology projects are located in Appendix F.

TABLE 4.6 Chiller Technology Audit Findings

\begin{tabular}{|c|c|c|c|c|c|c|}
\hline $\begin{array}{c}\text { Installed } \\
\text { Cost } \\
(\$)\end{array}$ & $\begin{array}{c}\text { Annual } \\
\text { Energy } \\
\text { Savings } \\
(\text { MMBtu) }\end{array}$ & $\begin{array}{c}\text { Annual } \\
\text { Demand } \\
\text { Savings } \\
(\mathbf{k W})\end{array}$ & $\begin{array}{c}\text { Annual } \\
\text { Energy } \\
\text { Cost } \\
\text { Savings (\$) }\end{array}$ & $\begin{array}{c}\text { Annual } \\
\text { O\&M Cost } \\
\text { Savings (\$) }\end{array}$ & $\begin{array}{c}\text { Total } \\
\text { Annual } \\
\text { Cost } \\
\text { Savings (\$) }\end{array}$ & $\begin{array}{c}\text { Simple } \\
\text { Payback } \\
\text { (years) }\end{array}$ \\
\hline $\begin{array}{l}\$ 656,000 \\
4,769\end{array}$ & 0 & $\$ 33,471$ & $\$ 0$ & $\$ 33,471$ & 19.6 \\
\hline
\end{tabular}

\subsubsection{Other Technologies}

The general category of "other technologies" includes the following measures: 
- cleaning of air conditioner (AC) evaporator and condenser coils

- caulk leaky through-the-wall heat pump piping

- rebalance fume hood air flow

- reduction in fume-hood air flow

- weatherstrip windows

- installation of floor insulation

- installation of attic floor insulation

- installation of automatic pool cover system

- installation of attic roof insulation

- installation of wall insulation

- installation of vinyl strip door on loading dock.

The identified projects range in cost from $\$ 100$ to $\$ 223,000$. The annual energy savings per project varies from $\$ 160$ to $\$ 82,000$. The simple payback calculations result in values ranging from 0.6 years to 10.9 years. Table 4.7 below presents the aggregated other technology findings. Data specific to the individual other technology projects are located in Appendix F.

TABLE 4.7 Other Technology Audit Findings

\begin{tabular}{|c|c|c|c|c|c|c|}
\hline $\begin{array}{c}\text { Installed } \\
\text { Cost } \\
\mathbf{( \$ )}\end{array}$ & $\begin{array}{c}\text { Annual } \\
\text { Energy } \\
\text { Savings } \\
\text { (MMBtu) }\end{array}$ & $\begin{array}{c}\text { Annual } \\
\text { Demand } \\
\text { Savings } \\
(\mathbf{k W})\end{array}$ & $\begin{array}{c}\text { Annual } \\
\text { Energy } \\
\text { Cost } \\
\text { Savings (\$) }\end{array}$ & $\begin{array}{c}\text { Annual } \\
\text { O\&M Cost } \\
\text { Savings (\$) }\end{array}$ & $\begin{array}{c}\text { Total } \\
\text { Annual } \\
\text { Cost } \\
\text { Savings (\$) }\end{array}$ & $\begin{array}{c}\text { Simple } \\
\text { Payback } \\
\text { (years) }\end{array}$ \\
\hline$\$ 447,693$ & 11,840 & 0 & $\$ 133,384$ & $\$ 0$ & $\$ 133,384$ & 3.4 \\
\hline $\begin{array}{l}\text { MMBtu refers to million Btu } \\
\text { 2 }\end{array}$ \\
\hline
\end{tabular}

\subsection{PNNL SITE-VISIT OPPORTUNITIES}

During the site visit to BNL, PNNL staff visited a sample of buildings with the goal of walking through a representative sample of BNL facilities. The buildings visited included the following:

- Central boiler plant facility

- Central chilled water facility

- $\quad$ Building 555

- $\quad$ Building 463

- $\quad$ Building 490

- $\quad$ Building 815 .

In addition, BNL staff provided a site-wide tour highlighting the diversity of the site, identifying mission-critical buildings, and identifying past and current energy-related projects. The resulting notes and observations of the site-wide tour and building walk-throughs were collected and are summarized below. This group of opportunities is not quantified as with the DOE-funded energy 
audits; rather, they are described qualitatively with the recommendation to be pursued in greater detail, if appropriate.

\subsubsection{Window Films}

During the site visit, a number of buildings were noted either to have window films, to have window films in need of replacement, or not have to window films at all. Additionally, during the site tour, BNL staff indicated that there is interest by the site in further penetration of this technology. By applying reflective window films, buildings can reduce solar heat gain and thus reduce the building's cooling load. However, because window films also block out solar radiation in the winter, the building winter heating load will be increased.

\section{Analysis Considerations}

- adequate existing shading of windows by trees or other buildings needs to be addressed

- reflective window films increase heating load in the winter months

- cost of fuel, installed cost of window films.

\subsubsection{Recover Waste Heat from Boiler Blowdown}

Boiler blowdown contains significant amounts of heat that can be captured by installing a boiler blowdown heat recovery system. Typically, these systems consist of a heat exchanger and/or a heat exchanger and flash tank to capture as much of the blowdown energy as possible. Potential uses for this captured energy include preheating boiler makeup water or feedwater, supplementing the necessary energy for deaeration operations, or to preheat other lowtemperature process applications.

\section{Analysis Considerations}

- verify continuous blowdown operation

- verify makeup water needs, systems with makeup water needs in excess of 5 to $10 \%$ are usually good candidates

- cost of fuel, steam, and recovery equipment.

\subsubsection{Ground-Source Heat Pump Systems}

Ground-source heat pumps (GHP) offer many advantages over conventional space heating/cooling systems - including air-source heat pumps. A GHP system operates at a higher level of efficiency than central heating systems; in the heating mode the efficiency may be 2 to 3 times higher than conventional combustion or direct resistance heating technologies. In the cooling mode, the GHP efficiency is usually higher than air-source technologies because of the lower heat sink (the ground) temperature.

The location of BNL is advantageous for this kind of technology because of its relatively moderate climate, yet still reporting significant heating and cooling needs. Additionally, the relatively high water table over which the site is located adds to GHP attractiveness.

One current mechanism for funding GHP systems is to take advantage of the Geothermal Technology-Specific ESPC. An installation of this technology may also take advantage of the other organizations including the Geothermal Heat Pump Consortium and the International 
Ground Source Heat Pump Association, which may offer technical assistance including design review and consultation.

\section{Analysis Considerations}

- availability of land to install vertical ground loop

- existing HVAC system efficiency and system configurations

- weather conditions

- $\quad$ soil conditions

- operations and maintenance impacts

- cost of fuel and equipment.

More information on the Geothermal Technology-Specific ESPC can be obtained either by contacting Mr. Doug Culbreth of the DOE Atlanta Regional Office at (919) 782-5238, or on the World Wide Web at http://www.eren.doe.gov/femp/financing/tecspec.html\#ghp

\subsubsection{Electric Motors}

Electric motors generally offer two main categories of savings opportunities. The first and usually most attractive is motor sizing; making sure the motor is properly sized for the load. Oversized motors not only waste energy, but they can also fail prematurely.

The second opportunity is to replace a standard efficiency motor with a high efficiency motor. While the cost justification of an "early replacement" scenario may not report very low paybacks, (paybacks will vary with hours of operation and electricity cost), the economics of the "replaceon-failure" scenario are usually very attractive.

In addition to replacement of failed electric motors, motor rewind is an option. In theory, rewinding a failed or near-failed electric motor should return the motor to its design efficiency (i.e., new efficiency), however, in practice this is not usually the case. One study (Montgomery 1984) indicated that electric motor efficiency is often compromised by standard motor rewind practices, thus making the initial low cost of motor rewinding a potentially poor investment. The performance degradation is linked to the process and temperatures used in "softening" the existing windings for removal. If not done properly, this process damages the stator resulting in increased core losses of the rewound motor. Depending on motor use, the purchase of an energyefficient motor replacement is usually more economic than rewinding an existing motor.

A very useful software package distributed as part of the Motor Challenge Program can help in identifying and quantifying electric motor savings opportunities. The software is called Motor Master and it is free to Federal agencies. An example of a savings and life-cycle cost analysis developed using the Motor Master software for a specific application at BNL is included in Appendix G. This example looks at replacing an existing ( 20 year old) 20 -hp air-handler motor (24-hour operation) with a new efficient motor. As this example demonstrates (simple payback of 3.1 years), replacing an old motor can result in significant cost-effective energy savings. (Note that estimated costs do not include site service and overhead fees.) Additional applications across BNL should be identified and analyzed.

\section{Analysis Considerations}

- $\quad$ existing equipment age and efficiency 
- annual hours of operation

- cost of fuel and equipment.

More information on the Motor Challenge Program and the Motor Master software can be found at http://www.motor.doe.gov/mainmc.shtml

\subsubsection{Central Compressed Air System}

As of 1997, the central compressed air facility had a rated capacity of 1,500 scfm with an estimated power use of $75,600 \mathrm{kWh} /$ month $^{\mathrm{a}}$. During the site visit, PNNL staff noted that the air intake for the compressor equipment was located inside the compressor housing. While convenient, this location allows for radiant energy to preheat the intake air and thus the compressor must work harder. By relocating the air inlet to an outside location (preferably on the north side of the building), a savings in energy use of about $2 \%$ can be achieved for a $10^{\circ} \mathrm{F}$ temperature reduction (ESI 1992).

\section{Analysis Considerations}

- existing equipment age and efficiency

- $\quad$ access to outside air

- cost of fuel and ducting.

\subsubsection{Wall/Window AC Equipment}

During the site visit, a very high penetration of wall/window AC equipment was noted. While these units are effective at space cooling, their efficiencies can vary widely, particularly for pre1994 equipment.

For future purchase of this equipment, BNL energy and procurement staff should take advantage of one or both of the following efficient procurement identification programs:

\section{ENERGY STAR® Program}

ENERGY STAR $®$ Room Air Conditioners feature high-efficiency compressors, fan motors, and heat transfer surfaces. In an air conditioner, the air is cooled when it passes over the refrigerant coils, which have fins, similar to an automobile radiator. The compressor sends the cooled refrigerant through the coils, and cools the air as it is forced over the coils. By using advanced heat transfer technologies, more of the heat from the air is transferred into the coils than in conventional models, saving energy required to compress the refrigerant. ENERGY STAR ${ }^{\circledR}$ Room Air Conditioners must exceed minimum Federal standards for energy consumption by at least $15 \%$.

More information on ENERGY STAR® room air conditioners can be found at http://www.energystar.gov/products/roomair/index.html

\footnotetext{
${ }^{a}$ Brookhaven National Laboratory Energy Management Group, "FY 1997 In-House Energy Management Factbook.
} 


\section{Federal Procurement Challenge}

FEMP issues a series of Product Energy-Efficiency Recommendations, as called for in EPAct, that identify "recommended" efficiency levels for energy-using products — i.e., levels that meet the criteria of the Executive Order and the FAR (Federal Acquisition Regulations). The recommendations also:

- Identify Federal supply sources that offer efficient products

- Suggest ways for buyers to identify efficient products when buying from commercial sources

- Present a cost-effectiveness example to help buyers judge whether a price premium is really "worth it"

- Offer tips to help buyers and users save energy without sacrificing comfort or performance

- Provide leads to other useful sources of information on product energy efficiency, such as the DOE/EPA program, the American Council for an Energy-Efficient Economy (ACEEE), Home Energy magazine, and many more.

More information on the Federal Procurement Challenge room air conditioners can be found at http://www.eren.doe.gov/femp/procurement/rac.html

\subsubsection{Chillers}

Chiller efficiency has increased significantly over the passed 20 years even after taking into account the switch from CFC to non-CFC refrigerants. Currently available chillers may be as much as twice as efficient as the chillers they are replacing, and these efficiencies are still improving.

On December 10, 1998 Secretary Richardson signed a memorandum to DOE program and field offices establishing a Departmental goal to retrofit or replace by 2005 all DOE chillers using Class I ozone-depleting refrigerants having 150 tons or greater of cooling capacity that were manufactured prior to 1984. Among others, this directive is designed to accomplish the following goals:

- reduce Class I ozone-depleting substance emissions

- help accomplish DOE energy conservation goals

- implement the President's directive to maximize the use of energy savings performance contracting.

While this directive specifically identifies 150 -ton chillers or greater, it also states that facilities should plan to eventually phase out all chillers using Class I refrigerants.

This memorandum can be found at http://www.eh.doe.gov/oepa/guidance/ozone

Clearly, chiller replacement projects can be difficult to economically justify based solely on the efficiency improvement. However, if a project is "bundled" with other measures (lighting, etc), as well as the retrofit designed to take advantage of proper chiller sizing and/or load reductions 
(resulting from the "other measures"), often the economics can be very attractive for consideration in a variety of alternative financing scenarios.

BNL has over 12,000 tons of space/process cooling refrigeration, including a 4,830-ton central chilled water facility (BNL 1997). Table 4.8 below presents the chiller tonnage (connected and used) by major refrigerant type at BNL- additional tonnage exists but is either backup or was replaced with connection to the central chilled water plant.

TABLE 4.8 BNL Connected Chiller Loads (tons) and Refrigerant Types

\begin{tabular}{|c|c|c|c|c|c|}
\hline Refrigerant & R-11 & R-22 & R-134A & $\begin{array}{c}\text { Lithium } \\
\text { Bromide }\end{array}$ & Various \\
\hline $\begin{array}{c}\text { Connected } \\
\text { Tons }\end{array}$ & 7,510 & 825 & 270 & 1,874 & 300 \\
\hline $\begin{array}{c}\text { Percent of } \\
\text { Total }\end{array}$ & $69.8 \%$ & $7.6 \%$ & $2.5 \%$ & $17.4 \%$ & $2.8 \%$ \\
\hline
\end{tabular}




\subsection{PROJECT IMPLEMENTATION PROCESS/SYSTEMS}

This section summarizes management and procedural conditions at BNL that may affect the development of alternatively financed energy projects including the following:

1. Project players and services

2. Project cost burdens

3. Energy costs and allocations.

\subsection{PROJECT SERVICE PROVIDERS AND STAKEHOLDERS}

Several organizations internal and external to BNL provide project development services or are stakeholders in the project implementation process. The key internal organizations and potential external organizations are discussed in this section.

\subsubsection{BNL Project Service Providers and Stakeholders}

The facilities management organization and processes are typical of academic and private industry: an enterprise-wide Facilities \& Operations directorate $(\mathrm{F} \& \mathrm{O})$ integrates planners, architects/engineers, energy management, operators, and maintenance staff under one chain-ofcommand. The organization of the major $\mathrm{F} \& \mathrm{O}$ departments related to alternatively financed energy projects are as follows:

Facilities \& Operations (F\&O) (Michael Bebon, Assistant Laboratory Director)

-- Plant Engineering Division (PED) (Edward Murphy, Manager)

--- Energy Management (Mark Toscano, Manager)

--- Engineering \& Construction Services (Michael Schaeffer, Manager) provides project management, design, and construction inspection

--- Operations \& Maintenance (Alanson Warren, Manager).

Facilities \& Operations staff perform most facility services. Major efforts, such as the construction of a new building, wing, or system, are typically subcontracted. The design of major efforts may also be subcontracted. A PED organizational chart is shown in Figure 5.1 and is also shown at http://epweb.pe.bnl.gov/manager.htm. Other BNL departments provide support for contracting/procurement, finance, and environment/safety/health.

Facilities \& Operations is one of the dozen top-level divisions that include six support divisions, such as finance and safety divisions. DOE manages BNL through the Brookhaven Group of the DOE Chicago Regional Office.

\subsubsection{Potential External Project Service Providers}

Although BNL staff provide most of the facility services, many service providers exist near-by because of BNL's location near metropolitan areas. Such services include comprehensive energy program/project management and specialty areas in architecture/engineering, construction, and maintenance \& operations.

LIPA, BNL's electrical provider (see http://www.lipa.state.ny.us/)] provides limited services for industrial/government customers (http://www.lipa.state.ny.us/conservation.html\#nightlight): 


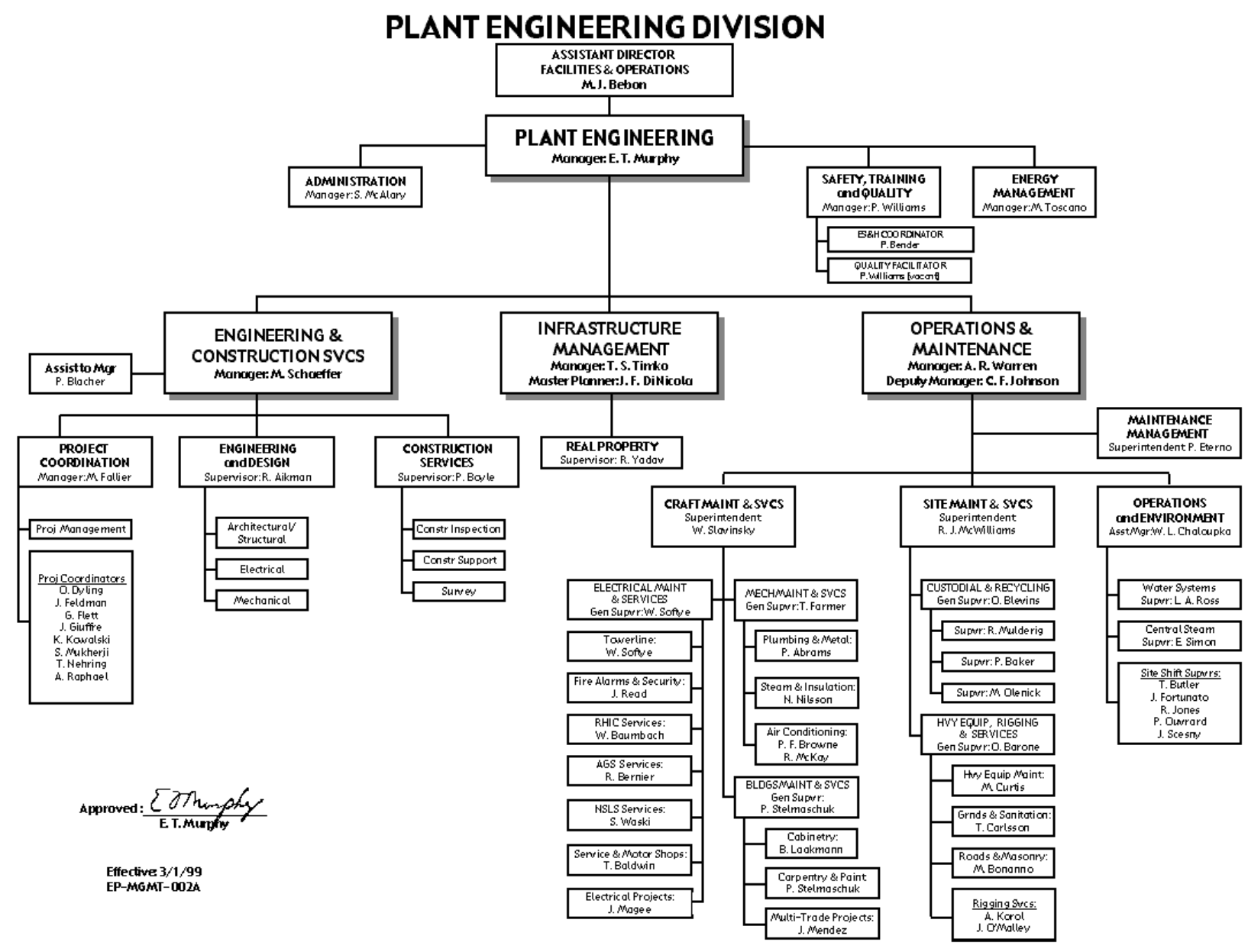

FIGURE 5.1. PED Organization Chart

- energy audits

- rebates for installing geothermal systems

- lower-cost light bulbs (e.g., compact fluorescents) and fixtures

- design, installation, and maintenance of night lighting for a monthly charge.

LIPA also performs or funds other development activities that may support an alternatively financed energy project. LIPA funds grants to a wide variety of organizations - including BNL for R\&D or pilot projects on emerging technologies including photovoltaics and electric vehicles. In particular, DOE, LIPA, BNL and the New York state energy office (NYSERDA - see below) partnered in 1999 to install a 7-kW fuel cell at BNL see

http://www.lipa.state.ny.us/rdapril24_99.htm).

LIPA also partners with Keyspan Energy on R\&D to provide Keyspan's wide range of services to Long Island including auditing, design, operations, and financing. Keyspan is a major regional producer and supplier of electricity and supplier of natural gas

(http://keyspanenergy.com/about/). 
The state of New York maintains a very active state energy office [NY State Energy Research and Development Authority (NYSERDA), http://www.nyserda.org/], which provides a wide range of services including the following:

- Technical assistance including audits and technology-specific evaluations through NYSERDA's FlexTech Program

- ESPC implementation based on experience gained through the following actions:

- Procured $\$ 65 \mathrm{M}$ of project financing capability through its tax-exempt Master Lease Alternative Financing Agreement with GE Capital Finance for the State EnVest Program

- Prequalified 23 ESCOs

- Maintenance of a database of 100 financiers for energy projects.

In addition, NYSERDA has experience with Federal agencies gained through a FEMP state grant to develop ESPCs for the local National Guard.

Table 5.1 summarizes the project phases and roles for traditional facility projects at BNL and illustrates how alternatively financed energy projects might be implemented.

\subsection{PROJECT COST BURDENS}

Like most organizations, BNL incurs internal services, management, and overhead costs that must be allocated to its products and services. In reference to facility projects, BNL allocates those overheads by charging a percentage-rate against the dollar value of each contract under a project. The rates can change during a fiscal year and often do.

\subsubsection{Project Management and Design}

BNL places all of the architect/engineer design services, construction administration and inspection, and project management efforts under a single category entitled Engineering, Design, Inspection, and Administration (EDIA). The Plant Engineering Department (PED) has set the EDIA budget rate at $14 \%$ of the construction estimate. Although PED staff usually provide all the EDIA services, sometimes they procure outside services. In this situation, PED may allocate between 8 and $10 \%$ of the $14 \%$ budget for outside services, but would retain the balance of between 4 and $6 \%$ for PED project management and support.

If the funding is a traditional congressional appropriation for a Line Item or General Program Project, the appropriation also provides funding beyond the EDIA 14\%. This additional funding covers PED's early project development work such as predesign scope, time, and money estimates.

\footnotetext{
${ }^{a}$ For traditional or alternative-financed construction projects, the contract amount includes all construction labor and materials, and the overhead and profit factors for the general contractor and any subcontractors. In design-build and ESPC contracts, the architecture/engineering service is also included in the contract amount.
} 
TABLE 5.1 Project Development Process at BNL

\begin{tabular}{|c|c|c|c|}
\hline \multirow[b]{3}{*}{ Phases/Activities } & \multicolumn{3}{|c|}{ Project Service Providers and Stakeholders } \\
\hline & \multirow{2}{*}{$\begin{array}{c}\text { Traditional } \\
\text { Appropriation } \\
\text { Projects } \\
\end{array}$} & \multicolumn{2}{|c|}{ Alternative Financed Projects } \\
\hline & & ESPC & $\begin{array}{c}\text { Utility or State } \\
\text { Funding Program }\end{array}$ \\
\hline Project Funding & HQ or BNL internal \$ & $\mathrm{ESCO}^{1}$ & Utility/State \\
\hline Capital Planning & $\begin{array}{c}\text { F\&O Infrastructure } \\
\text { Mgmt }\end{array}$ & $\begin{array}{c}\text { F\&O Infrastructure } \\
\text { Mgmt }\end{array}$ & $\begin{array}{c}\text { F\&O Infrastructure } \\
\text { Mgmt }\end{array}$ \\
\hline \multicolumn{2}{|c|}{ Project Development/Implementation } & & \\
\hline Project management & F\&O Proj Coord & $\mathrm{ESCO}^{1}$ & Traditional options \\
\hline $\begin{array}{l}\text { Predesign scope and cost } \\
\text { estimates }\end{array}$ & F\&O Eng \& Design & $\mathrm{BNL}$ or $\mathrm{ESCO}^{1}$ & \\
\hline $\begin{array}{l}\text { Programming (project } \\
\text { definition) }\end{array}$ & F\&O Eng \& Design & $\mathrm{ESCO}^{1}$ & $\downarrow$ \\
\hline DOE review/approval & Varies & $\begin{array}{l}\text { DOE Brookhaven } \\
\text { Group }\end{array}$ & $\begin{array}{l}\text { DOE Brookhaven } \\
\text { Group }\end{array}$ \\
\hline Design & $\begin{array}{c}\text { F\&O Eng \& Design or } \\
\text { A/E subcontract }\end{array}$ & $\mathrm{ESCO}^{1}$ & Traditional options \\
\hline Contract documents - design & $\begin{array}{c}\text { F\&O Eng \& Design or } \\
\text { A/E subcontract }\end{array}$ & $\mathrm{ESCO}^{1}$ & \\
\hline $\begin{array}{l}\text { Contract documents - } \\
\text { procurement/bidding }\end{array}$ & Contracts & $\mathrm{ESCO}^{1}$ & \\
\hline Construction & Contractor & $\mathrm{ESCO}^{1}$ & \\
\hline $\begin{array}{l}\text { Construction - BNL } \\
\text { oversight \& inspection }\end{array}$ & $\begin{array}{c}\text { F\&O Eng \& Design or } \\
\mathrm{A} / \mathrm{E}\end{array}$ & $\mathrm{ESCO}^{1}$ & \\
\hline Operations & $\mathrm{F} \& \mathrm{O} O \& M$ & $\mathrm{ESCO}^{1}$ & \\
\hline \multicolumn{4}{|c|}{$\begin{array}{l}\text { Notes } \\
\text { 1. BNL departments and staff noted in the Traditional column need to specify the level of control or } \\
\text { input they require over the ESPC and Energy Services Contractor (ESCO). }\end{array}$} \\
\hline
\end{tabular}

\subsubsection{Overheads}

A wide variety of BNL overheads are combined into the following adders:

- Material burden of $7.75 \%$, applied to the first $\$ 600 \mathrm{~K}$ of a contract

- Traditional lab-wide general and administrative (G\&A) adder of $12 \%$ applied to the first $\$ 600$ $\mathrm{K}$ of a contract 
- Site support general and administrative (G\&A) of $25 \%$ applied against the material burden and lab-wide G\&A.

Note that the material burden and G\&A adders apply only to the first $\$ 600 \mathrm{~K}$ of the procurement or contract amount. This means a $\$ 10 \mathrm{M}$ contract incurs the same dollar-burden as a $\$ 600 \mathrm{~K}$ contract. Consequently, significant savings can be realized by packaging smaller projects into a single, large contract. Similarly, savings can be achieved by having design services included in the contract scope of a design/build project or an alternatively financed energy project.

The sequencing of which adder is applied to the contract first can have an impact on the bottom line project cost. The sequencing depends on how a project is implemented within BNL's organizations. The following project scenario and implementation options are provided to help understand the bottom-line dollar impact. The scenario used herein is a moderately large $\$ 1 \mathrm{M}$ construction project with the standard 14\% EDIA cost, for a total project cost of \$1.14 M. The implementation options are as follows ${ }^{\mathrm{a}}$ :

- Option 1 is the traditional construction project, wherein PED provides the EDIA and a general contractor builds the project.

- In Option 2, PED purchases the majority of the construction materials (e.g., lighting, motors, controls) and a contractor installs the materials.

- In Option 3, PED procures and installs the materials.

- Option 4 is similar to Option 1 except that the design services are provided by the ESCO instead of PED.

The bottom-line cost impact of the implementation options and their adders is shown in Table 5.2 (see Appendix $\mathrm{H}$ for indirect overhead calculations).

As shown in the table, the adders can increase the project cost by between $14 \%$ and $36 \%$. The difference between the lowest (\#4) and the highest cost option (\#3) is an increase of $\$ 250 \mathrm{~K}$ (19\%). This cost difference is significant not only for the additional dollars, but also because the additional cost extends the payback by the same $19 \%$. For example, if an underlying design/construction project has a 10-year payback, then the more costly implementations option would extend the payback to almost 12 years.

The higher costs of Options 2 and 3 result solely from the breakup of the project into smaller contracts or procurements that are less than the $\$ 600 \mathrm{~K}$ breakpoint for the Material Burden and G\&A adders noted above. Conversely, the lower cost of Option 1 is from combining activities into a single alternatively financed energy project contract. Finally, the lowest cost (Option 4) is because one last activity - the project design services - is moved to the alternatively financed energy project contract.

\footnotetext{
${ }^{a}$ BNL contracts specialist Ed Byrne, August 11, 1999. Byrnes provided an Excel spreadsheet that defined the concepts and calculations with Mark Toscano's input for Options 1 through 3. This report defined Option 4 for the purpose of exploring other options. The calculations for all options are presented in greater detail in Appendix $\mathrm{H}$.
} 
TABLE 5.2. Burdens on a $\$ 1$ M Project

\begin{tabular}{|lr|rr|r|}
\hline Implementation Option & $\begin{array}{r}\text { Project Cost w/ } \\
14 \% \text { EDIA }\end{array}$ & $\begin{array}{r}\text { Indirect } \\
\text { Burdens }\end{array}$ & $\begin{array}{r}\text { Effctv } \\
\%\end{array}$ & Total Project \\
\hline 1. Traditional construction contract & $1,140,000$ & 187,505 & $16.4 \%$ & $1,327,505$ \\
2. BNL buys materials, contractor installs & $1,140,000$ & 327,975 & $28.8 \%$ & $1,467,975$ \\
3. BNL buys and installs materials & $1,140,000$ & 414,270 & $36.3 \%$ & $1,554,270$ \\
4. Alternative financed contract & $1,144,800^{1}$ & 159,681 & $13.9 \%$ & $1,304,481$ \\
Variance (difference between maximum and minimum costs) & & 249,789 \\
\% Variance (Variance/Minimum) & & $19 \%$ \\
1. Project cost is slightly higher under Option 4 because some $(\$ 80 \mathrm{~K})$ of the EDIA fee is included in the construction cost and \\
that results in a slightly higher fee $(\$ 4.8 \mathrm{~K})$.
\end{tabular}

BNL procurement staff note that if Option 2 or 3 were to be used to implement a large project, then a special arrangement would be attempted to make the net burden similar to Option 1. ${ }^{\text {a }}$ Careful consideration should be given to implementation options to minimize overhead costs.

\subsection{ENERGY COSTS AND ALLOCATIONS}

Energy costs and the allocation method for those costs can significantly influence the feasibility or cost-effectiveness of an alternatively financed project. Those key elements are outlined in this section.

\subsubsection{Energy Costs}

The Energy Management Group of the Plant Engineering Division routinely negotiates its rates for electricity, natural gas, and oil/LPG. The effective, blended electricity rate is currently about 6 cents $/ \mathrm{kWh}$ and BNL expects it will decrease to about 5.5 cents. The daily effective rates can range from 5 to 8 cents/kWh depending on the time of day. The underlying supplier's rate is 2.3 cents (soon to be 2.1 cents) from the New York Power Authority, plus kW charges from three power wheelers. In FY97, BNL used 257,000 MWh of electricity, of which most was for R\&D loads (see Table 5.3). Additional details are posted on BNL's web site at http://www.emg.bnl.gov/enstats.htm FY99 loads were similar, but BNL expects loads to significantly increase when a very large R\&D relativistic ion collider comes on-line.

TABLE 5.3. Distribution of Energy Use in FY97

\begin{tabular}{|lrr|}
\hline End-Use & MWh & \\
\hline Process, mostly R\&D equipment & 167,943 & $65.3 \%$ \\
Buildings & 77,641 & $30.2 \%$ \\
Central chiller plant & 10,567 & $4.1 \%$ \\
Central steam plant & 1,147 & $0.4 \%$ \\
& 257,298 & $100.0 \%$ \\
\hline
\end{tabular}

\footnotetext{
${ }^{\mathrm{a}}$ Telecon with Mark Toscano, November 22, 1999
} 
In FY97, BNL's natural gas rate was \$3.12 a decatherm (DT), and \#6 fuel oil rate was 43

cents/gallon for a centralized steam plant. The FY98 gas consumption was 628,000 DT, and fuel oil was 330,006 gallons to produce 505,249,000 million pounds of steam.

\subsubsection{Energy Cost Allocations}

PED maintains an electricity metering and reporting system that covers all major buildings and R\&D equipment. The reporting is online and available to BNL staff. PED pools the electricity cost with the metering program staff support cost. Then, PED allocates the cost directly to the end-use programs, including the R\&D programs. Consequently, R\&D staff track BNL's online hourly-load data to avoid incurring the high demand charges incurred when exceeding BNL's peak demand limit.

PED also maintains metering for steam, and issues mock bills to the end-use programs. BNL includes the actual steam costs in the space charge rate at this time. Other utility costs, such as O\&M for the central chilled water plant, are also sent through the BNL space chargeback system. 


\subsection{SITE-SPECIFIC PROJECT CONSIDERATIONS}

In developing project recommendations, it is important to consider key issues and concerns specific to this site. These issues and concerns were raised during the interview process and demonstrate the need to discuss potential projects with all staff involved in the project development, approval, and implementation process.

\subsection{CONTRACT TERMS}

One key feature of the alternative financing methods summarized in Section 3 is that contract terms extend beyond the completion of construction and may extend out to 25 years in the case of ESPCs. These multi-year contract terms are necessary to create the cash flow (repayment) stream necessary to cover the investment and financing costs. But while Federal sites are now able to enter into multi-year contracts to implement energy efficiency, the question of what contract term is acceptable must be addressed by each site considering such financing arrangements.

During interviews with the site staff, many were asked about how they thought the site's decision-makers (those individuals with authority to approve/disapprove a proposed project) would react to projects funded over multiple years. This issue has not yet been raised at BNL, especially in conjunction with a specific project. No one felt that a 20 to 25 year term would be viewed favorably at the site, while several felt that terms in the neighborhood of up to 10 years might be considered feasible. The reasoning behind the 10-year term was that the Lab currently engages in some lease contracting with terms of up to 10 years, as well as the term of the Lab's current management and operations contract is a 5-year contract with a 5-year renewal option. Thus, an alternative financing arrangement within this established time span would not require precedent and may be open for consideration.

If the site is interested in pursuing alternative financing, a decision on the maximum contract term needs to be made up-front because this decision will impact the degree of investment available. If the site determines that 10 years is the maximum contract term, an ESPC project would likely need to have a bundled simple payback period in the neighborhood of 5 years to allow repayment of initial investment plus finance charges. Note that this "limitation" is also virtually in place with regards to utility financed projects per the recent finding from the DOE Deputy General Counsel (Section 3.3 and Appendix E). Limiting projects to a simple payback of 5 years or less probably eliminates the possibility of completing any chiller replacements, which is a site infrastructure need, via ESPC and utility financing.

\subsection{UP-FRONT/SITE INCURRED PROJECT COSTS}

BNL staff recognize that alternatively financed projects do require up-front capital to cover site technical and contracting staff efforts. However, these costs incurred in-house are not covered by the private sector financier and must be provided for internally. (Note that when projects were financed by IHEM funding, site technical and contracting costs were included as a part of the overall IHEM project funding amount.) In the case of BNL, these costs appear as hourly charges for the staff time in the project's identification, development, and implementation stages. Additional to the staff hourly rates is the cost burdening, which is necessary to finance the operation of the Lab's Plant Engineering Division (see Section 5.2). While overhead structures and rates vary from site-to-site, this type of organizational and overhead structure is in place at many large Federal sites. Staff at BNL are very keen to the up-front site costs associated with alternatively financed projects and feels that this issue needs to be more directly addressed in the FEMP information products. The issue of funding site technical and contracting staff in the 
identification, development, and implementation must be identified in the earliest stages of the project development process. Some options the site may wish to consider include: requesting site and/or program funding to cover these efforts; requesting the waiving or exempting of some or all of the overhead fees; requesting funding from DOE headquarters. In the event that overhead fees are waived or exempted, those costs incurred by the site in the placement of an alternatively financed project will have to be absorbed elsewhere on the site. In addition, the site may desire to track these costs as an overall assessment of the cost effectiveness of an ESPC project that compares the sum of investment and support costs to the energy cost savings realized.

\subsection{UNION CONSIDERATIONS}

A key component of ESPCs is the energy/cost savings performance guarantee. It is this provision that not only necessitates annual measurement and verification of energy savings, but also strongly encourages the energy savings performance contractor to perform regular equipment maintenance and even operate equipment to ensure efficient operation and the realization of the guaranteed savings. Thus, performance based contracts involving complex energy-using equipment/systems such as chillers and utility plants are likely to include the assigning of contractor staff to provide services that are already performed by site staff. In the case of BNL, site staff that are represented by a union perform operations and maintenance services. Thus, a performance based contract involving contractor staff performing equipment/systems operations and maintenance is an issue that needs to be addressed between the site and the union prior to developing such a contract.

It is not possible to recommend a position at this time because such a project has not been scoped out. In general, there are a limited number of ways is which such an issue can be addressed. Depending on the project scope, the union and the Lab may agree that having contractor employees on site is not an issue and the project may proceed as planned. However, if the union does not agree with the placement of contractor employees on site to complete the operations and maintenance of systems installed under a performance based contract, the site may also consider having these operations and maintenance services performed by the site staff. In this case, the site would wind up accepting the performance risk associated with the contract. This means that if energy savings (felt to be) contingent upon the performance of certain operations and maintenance are not realized, the contractor may shift the burden to the government while still collecting full payment.

The discussion above oversimplifies the realm of issues faced and potential solutions available to the Lab in dealing with site staffing issues. However, this simplification is intended because development of a performance-based contract is a complex process that requires time to execute. Decisions such as the use of site operations and maintenance staff on site need to be made upfront, before a significant effort has been invested in the project development only to run into a potentially major obstacle. As an initial step, the site should make sure that the union officials are brought into discussions concerning consideration of any performance based contracts and kept appraised of any subsequent project development activities.

\subsection{INCENTIVES TO SAVE ENERGY}

Two key points regarding incentives to save energy were made during the interviews. First, building comfort (HVAC) is a part of the tenants' space charge. Reductions in the energy use associated building comfort such as hours of operation and modified temperature settings might not even produce a noticeable change in the space charge out rates, thereby offering no tangible benefit. Second, the true incentive for the programs to save energy is that cost savings associated 
with more efficient use can be rolled back into mission related work. Thus energy efficiency is sold to the programs on the basis of program benefits and benefits to science. These "incentives" only reinforce the outstanding work done by the site staff in meeting the 2000 energy reduction goal of $20 \%$. However, the meeting of energy reduction goals is not necessarily an incentive to the Lab's energy users.

\subsection{UNIQUE ELECTRIC UTILITY ARRANGEMENT}

As covered in Sections 2 and 5.3.1, the Lab purchases its electricity from NYPA although it is located in the LIPA service territory. In addition to being one of the three electric power wheelers to the site, LIPA also provides electric power over the negotiated purchase amount between the Lab and NYPA. In the past, NYPA has worked with the Lab to help finance some energy-efficiency measures and was, in fact, discussing the possibility of funding a free cooling retrofit when the DOE moratorium on financing from utilities took effect It is hoped that discussions on this free cooling project will resume now that DOE sites are again able to accept utility financing. While it is unclear what type of business relationship the site has with LIPA and if LIPA would be interested in offering financing for energy-efficiency projects, this option should be further explored with LIPA.

\subsection{EXEMPT FACIILITIES UNDER EXECUTIVE ORDER 13123}

Since the passage of the Federal Energy Management Improvement Act of 1988 (Public Law 100-615), Federal agencies have been tasked with achieving reductions in building energy use relative to the baseline year of 1985 . The initial energy reduction goal established was $10 \%$ by FY 1995, however subsequent legislation and executive orders, the most recent being Executive Order 13123 (Greening the Government Through Efficient Energy Management), have gradually increased this goal to a $35 \%$ reduction by fiscal year 2010. However, as part of these facility energy reduction goals, agencies have been permitted to exempt and separately report energy used in buildings that house energy intensive activities, for which a separate efficiency goal was established. In an effort to more strongly encourage the capture of available cost-effective energy savings in these exempt buildings, section 203 of Executive Order 13123 established a 20\% by 2005 and $25 \%$ by 2010 relative to 1990 reduction goal for industrial and laboratory and facilities. The Executive Order went on to state "No facilities will be exempt from these goals unless they meet new criteria for exemptions as issued by DOE." The significance of this relative to the identification of potential projects and financing methods is that the goal attainment status of the site might be impacted, and this might create a new impetus for the site to focus on buildings currently reported as exempt. While this issue does not impact any of the project recommendations made in Section 8, it is recommended that Lab staff work with the program counterparts in the FEMP office to stay informed of any developments on this front. 


\subsection{PROJECT ALTERNATIVES}

Up to this point this report has reviewed the energy-efficiency financing alternatives available to the site, summarized potential energy conservation measures, and looked at the organizational structure responsible for implementing energy efficiency in terms of roles and resource allocation. This section identifies several potential project scenarios that will be discussed in terms of the information presented in the earlier sections of this report. Project alternatives will be presented for appropriated funding and each alternative financing method discussed in Section 3.

In general, the list of potential measures as identified by the recent energy audits, along with the potential measures identified by PNNL staff during their visit, indicates that there are a significant number of cost-effective actions available for the site to consider. A more detailed review of the energy identified measures is presented in Section 7.1 below. In addition, the site also has an infrastructure need to replace or retrofit several chillers in accordance with the DOE departmental goal for phasing out of Class I ozone-depleting substances.

\subsection{SUMMARY OF ENERGY AUDIT RECOMMENDATIONS}

Before considering the various project financing alternatives, it is useful to look at the data available regarding identified ECMs. The energy audits were completed for 44 buildings, which represent $55 \%$ of the on-site building space. The ECMs and their associated costs, savings, and paybacks are summarized in Appendix F.

The simple payback periods for the ECMs identified in the audits range from 0 years (immediate) to 25.8 years. There are numerous ECMs with simple payback periods of 1 year or less and include changing setpoints for HVAC and domestic hot water systems, installing programmable thermostats, faucet aerators, occupancy sensors, and low-flow showerheads, cleaning coils, and changing a lighting operating schedule. The estimated total cost to implement these measures is $\$ 23,263$ with a resulting estimated annual energy savings of $\$ 64,589$. The bundled simple payback period of these measures is 0.4 years. Note that the cost estimates found in the audits do not include site staff support costs and overheads. Clearly these are measures that the site must consider completing outside any sort of alternative financing arrangement.

ECMs with simple payback periods in the range of 1.1 to 2.0 years require significantly more capital. The total estimated implementation cost for all ECMs in this payback range is $\$ 72,922$ with estimated annual savings of \$52,032 resulting in a bundled simple payback period of 1.4 years. ECMs in this group include many of the measures identified above along with installing compact fluorescent lamps, T-8 lamps and electronic ballasts, and new exit signs; testing and replacing faulty steam traps; reducing fume hood air flow; and reducing supply air flow. It should be noted that a site-wide project to replace the exit signs has already been funded. Also, consideration to reduce fume hood air flow has previously been considered by the Lab. In short, there are unresolved concerns regarding the safety of modified fume hood operation as well as the total costs required to retrofit the systems in compliance with appropriate codes.

Most of the ECMs in the simple payback range of 2.1 to 6.0 years cover interior lighting, lighting controls and HVAC controls. The total estimated cost for all ECMs in this range is $\$ 1,097,135$ with estimated annual savings of $\$ 257,315$ resulting in a bundled simple payback of 4.3 years. The single largest ECM identified in this group is the installation of two-speed DDC fan control switches in Building 555, but this system is scheduled for retrofit using DOE funds. Projects with simple paybacks in the range of 6.1 to 10.0 years cover lighting, lighting controls, HVAC 
equipment and controls, motors, insulation, and an automatic pool cover. The total estimated cost for all ECMs in this range is $\$ 1,049,841$, with estimated annual savings of $\$ 130,089$ resulting in a bundled simple payback of 8.1 years. There are eight projects with simple paybacks in the range of 10.1 to 15.0 years. ECMs in this range cover lighting, insulation, and motors. There are a number of notable projects with estimated simple payback periods greater than 15 years. First are the three chiller projects identified in the audit. Simple payback periods in this range are not uncommon for chiller retrofits. Also identified are five solar domestic hot water systems. Table 7.1 is a summary of the potential investments and savings for each of these bundled ECM groupings for all measures identified in the energy audits, as summarized in Appendix F.

TABLE 7.1 Summary of Audit Identified Potential Investments and Savings for ECMs Bundled by Simple Payback Period

\begin{tabular}{|l|c|c|c|}
\hline $\begin{array}{l}\text { ECM Simple } \\
\text { Payback Range in } \\
\text { Years }\end{array}$ & $\begin{array}{l}\text { Total Estimated } \\
\text { Investment Potential }\end{array}$ & $\begin{array}{l}\text { Total Estimated } \\
\text { Annual Cost Savings }\end{array}$ & $\begin{array}{l}\text { Bundled Simple } \\
\text { Payback Period in } \\
\text { Years }\end{array}$ \\
\hline 0.0 to 1.0 & $\$ 23,263$ & $\$ 64,589$ & 0.4 \\
\hline 1.1 to 2.0 & $\$ 72,922$ & $\$ 52,032$ & 1.4 \\
\hline 2.1 to 6.0 & $\$ 1,097,135$ & $\$ 257,315$ & 4.3 \\
\hline 6.1 to 10.0 & $\$ 1,049,841$ & $\$ 130,089$ & 12.1 \\
\hline 10.1 to 15.0 & $\$ 274,955$ & $\$ 22,741$ & 19.8 \\
\hline Greater than 15.0 & $\$ 1,227,800$ & $\$ 62,115$ & \\
\hline
\end{tabular}

It should be noted that for the purposes of the discussion presented in this section, it was assumed that the assumptions and calculations contained in the audits are accurate and correct. While several of the assumptions and calculations used were questioned, it is felt that the listing of the energy conservation measures identified provides a reasonable starting point when estimating investment potential. On the other hand, as noted in Section 4, the BNL staff feel that the construction costs at the Lab tend to run significantly higher than estimated costs. One possible way to account for this difference is to apply a location factor as recommended by the 2000 Means Cost Data (R.S. Means 1999) manuals, which for locations on Long Island were in the neighborhood of $130 \%$ (or 1.3 times the estimated cost). When this location factor is applied to the estimated costs of the Appendix F measures, the distribution of ECMs identified in Table 7.1 is significantly impacted, as demonstrated in Table 7.2.

TABLE 7.2 Summary of Audit Identified Potential Investments and Savings for ECMs Bundled by Simple Payback Period Adjusted with Location Factor of 1.3

\begin{tabular}{|l|c|c|c|}
\hline $\begin{array}{l}\text { ECM Simple } \\
\text { Payback Range in } \\
\text { Years }\end{array}$ & $\begin{array}{l}\text { Total Estimated } \\
\text { Investment Potential }\end{array}$ & $\begin{array}{l}\text { Total Estimated } \\
\text { Annual Cost Savings }\end{array}$ & $\begin{array}{l}\text { Bundled Simple } \\
\text { Payback Period in } \\
\text { Years }\end{array}$ \\
\hline 0.0 to 1.0 & $\$ 27,743$ & $\$ 62,523$ & 0.4 \\
\hline 1.1 to 2.0 & $\$ 87,299$ & $\$ 49,903$ & 1.7 \\
\hline 2.1 to 6.0 & $\$ 560,434$ & $\$ 141,580$ & 4.0 \\
\hline 6.1 to 10.0 & $\$ 1,191,962$ & $\$ 155,700$ & 11.2 \\
\hline 10.1 to 15.0 & $\$ 1,098,157$ & $\$ 97,865$ & 23.4 \\
\hline Greater than 15.0 & $\$ 1,904,096$ & $\$ 81,250$ & \\
\hline
\end{tabular}


A comparison of Tables 7.1 and 7.2 reveals the impact resulting from adjusting the cost estimates upward to reflect local cost factors. In short, the investment potential in ECMs with simple payback periods of 6.0 or less years falls from $\$ 1,193,319$ in Table 7.1 to $\$ 675,476$ in Table 7.2. This is significant because ECMs with fast simple payback periods are needed if ECMs with longer simple payback periods are to be bundled into alternatively financed projects.

Again it must be pointed out that

- $\quad$ estimated investment values in Tables 7.1 and 7.2 do not take into account the costs to cover Lab staff time and overhead

- additional opportunities beyond those included in the building energy audits were identified by PNNL staff during the site visit but are not taken into account in Tables 7.1 and 7.2

- potential opportunities in buildings not covered in the audits are not taken into account in these summary tables

- $\quad$ staff at the Lab feel the location factor may be significantly higher than $1.3(130 \%)$.

\subsection{APPROPRIATED FUNDS}

The availability of appropriated funds for energy-efficiency projects is considered scarce because DOE no longer funds projects through appropriations. However, the Lab is still able to appropriate funds to projects that result in energy savings based on overall infrastructure priorities. Funding for these types of projects is awarded on a primarily competitive basis where projects are prioritized.

There are several scenarios for the using appropriated funds to implement energy-efficiency projects.

- Scenario 1: The site can fund the purchase and installation of ECMs under a strictly competitive process - this is the status quo. Included in the funding amount are funds to cover site staff and overhead charges. Because of the competitive nature of these funding awards, projects must demonstrate a high degree of need/benefit to the Lab.

- Scenario 2: The site can establish priority to provide funding to implement low/no cost measures with simple paybacks up to a certain simple payback threshold. ECMs falling outside the established threshold would still compete for project funding under the system currently in place.

- Scenario 3: Funding to cover staff time to identify and implement alternatively financed project(s) could be requested and awarded. It will in fact be necessary for the site to identify and set aside funds to cover project staff time if any of the alternative financing methods are pursued. In addition, the site is still able to pursue to implementation approaches identified under Scenario 2 in combination with Scenario 3.

\subsection{ENERGY SAVINGS PERFORMANCE CONTRACTS}

There are several issues that need to be addressed when evaluating the ESPC project potential at BNL, the first of which is the investment potential. In addition to the ECMs identified, the 
investment potential is also affected by the maximum contract term the Lab may be willing to accept. The rule-of-thumb is the contract term for an ESPC is twice the project's simple payback period. If the Lab were to place a contract term limit of 10 years (see Section 6.1), a package of ECMs would then be bundled to construct a project package with a composite simple payback of around 5 years. The resulting investment potential based on the ECMs identified in Appendix F with a composite simple payback of 5 years would then be $\$ 2,198,486$ for the audit cost estimates, and $\$ 1,966,982$ for the location adjusted cost estimates.

However, per discussions with laboratory staff, it is expected that many, if not most, of the measures with simple payback periods of less than 1 year will be completed using site staff and resources. The impact of removing these ECMs from the potential project portfolio is the reduction of the investment potential down to $\$ 1,836,964$ when using the audit cost estimates and $\$ 1,331,151$ when using the location-adjusted cost estimates. But this range of investment potential still assumes that all ECMs identified in the audits will be implemented by the site if given the choice, and that all the savings and cost estimates are correct. Experience dictates that all identified measures will not be implemented for a number of reasons including the following:

- further analysis will result in reduced energy savings potential and/or higher installation costs

- certain ECMs may not be acceptable for their proposed (laboratory) environments

- $\quad$ some identified measures may be mutually exclusive

- $\quad$ some measures may already be included as a part of other planned facilities projects.

The degree of decrease in investment potential resulting from these factors cannot be reasonably estimated at this time. However, it would not appear to be unreasonable to suggest a reduction in investment potential resulting from these factors of about $50 \%$ bringing the investment potential down to the $\$ 650 \mathrm{~K}$ to $\$ 900 \mathrm{~K}$ range, which is still large enough investment potential to generate the interest of the regional ESCOs under the DOE Northeast regional IDIQ (Super-ESPC). In addition, as noted in Section 4.2.3, the local conditions may be favorable to using the DOE technology-specific Super-ESPC for geothermal heat pumps. It is recommended that the Lab further refine this investment potential range by more closely examining the location cost factor and the individual audit recommendations.

There are several options available to the site in terms of packaging ECMs into a Super-ESPC delivery order. Additional factors affecting how a project (delivery order) might be packaged include the following:

- The level of appropriated funds required by the site to support the implementation of ESPC projects. It is believed that staff project support costs will increase with increasing overall project capital investment, but estimates that take into consideration overall project scope will need to be developed for individual project packages.

- $\quad$ Site decision to fund completion of ECMs based on site need.

- Site decision to complete low/no cost ECMs using appropriated funds. If the site were to complete these measures using appropriated funds, the bundled simple payback of the remaining ECMs would be driven higher.

- Complexity of measures and the corresponding level of measurement and verification required to annually administer the contract over the contract term. Measures such as lighting replacements, thermostat replacements, and constant load motor replacements can 
have annual savings estimated by using agreed upon engineering calculations, while measures such as chiller replacement require a much more rigorous annual review. On the other side, measures such as the changing of setpoints are extremely easy and are likely to be much easier to complete with in-house staff as opposed to contract employees.

- Union issues, especially those involving the maintenance of equipment by contractor staff.

- Operational control issues such as who controls equipment setpoints and penalties if controls are by-passed by Lab staff.

\subsection{UTILITY FINANCED PROJECTS}

In light of the recently issued opinion regarding DOE sites participating in financing programs, BNL is also a candidate site for utility project financing. In particular, there are many ECMs with simple paybacks that will allow for contract terms of less than 10 years with sufficient savings to pay all costs. These requirements are virtually the same as for ESPCs except that the contract term is limited to 10 years and this would impact how the ECMs would be bundled. One significant difference between ESPCs and utility financed projects is that utilities may have much lower investment thresholds allowing the site to package much smaller retrofits. The availability of utility financing and its terms must be verified with the utility.

It should also be noted that some utilities still offer financing through demand side management programs that help defray the actual purchase and installation costs. These programs were much more popular in the early 1990s, and it is understood that at the time of this evaluation this type of financing was not available to the Lab from LIPA. However, the Lab is encouraged to continue to check back with the utility in the event that such offerings do become available again. If this becomes the case, the Lab should immediately look to see if the eligible ECMs are cost effective and then consider them within the larger picture of site-wide opportunities. Again, the Lab will have to check with the utility to determine if this type of funding is available and under what conditions.

\subsection{BONNEVILLE POWER ADMINISTRATION}

Funding from BPA is an option. This funding can be packaged to cover a full range of ECMs, or it can be used to target certain strategic options. The best example of a strategic option would be the use of BPA arranged financing to cover the purchase and installation of new chillers in an effort to meet the DOE Class I ozone depleting substances phase-out goal. As the audit estimates help demonstrate, chiller replacements on the basis of a 10-year simple payback are not likely. However, since the chillers would result in an energy-efficiency improvement, such a project would be eligible for BPA funding. Because the BPA financing option is flexible, the Lab can mix appropriated funds into the overall project financing plans. Whichever way the financing package is structured, the Lab would need to identify the financing repayment stream because the resulting energy savings would probably not be sufficient to cover the repayment costs. 


\subsection{RECOMMENDATIONS FOR ENERGY-EFFICIENCY PROCUREMENT STRATEGY}

The project team feels there are two basic conclusions that can be drawn from the information gathered on energy management at the Lab. First, the site has been very successful in its energy management efforts to date. The current focus on utilities procurement is very well directed, and future energy management efforts should include continued emphasis on utilities procurement, more specifically that of electricity. Second, as demonstrated by the recently completed audits and observations during the site tours, there are significant cost-effective retrofit opportunities available to the Lab, even at the "low" electric price of 6 cents per kWh blended. Further, many of these efficiency measures may be good candidates for alternative financing when bundled together, although it is recognized that funding is required to develop and manage alternatively financed projects. With that in mind, the following recommendations are made.

RECOMMENDATION 1: Resolve the issues identified in Section 6 and any other alternative financing project related issues identified by the Lab. If these issues are not addressed up-front, they will linger on as stumbling blocks for all alternative finance project proposals. The issue most frequently mentioned during the site visit was that of obtaining the funds necessary to cover the project development and management costs (Sections 5.2 and 6.2). While these costs will most likely have to be covered by overhead funding, there does appear to be some flexibility on the part of the Lab in determining the hourly rate charges and funding sources. Table 5.2 provides an estimate of the site funding required to develop and manage an energy-efficiency project with a capital investment of $\$ 1.0 \mathrm{M}$ under the overhead financing and charging system in place at the time of the visit. With this in mind, the Lab can evaluate the various financing alternatives to deal with the project development and management financing issue. For example, delegate as much of the design/build process as possible to the ESPC contractor. Likewise, issues such as O\&M contractors and project terms must also be addressed because these can be critical components in an alternative financing strategy.

RECOMMENDATION 2: Implement the low/no cost ECMs using site funds, identified in the audits, as soon as possible. A significant number of ECMs with simple paybacks of less than 1 year were identified with at an estimated cost of $\$ 23,263$ (unburdened) and resulting annual savings of $\$ 64,589$, per the energy audits. ECMs with simple paybacks of less than 2 years have a total estimated cost of $\$ 96,185$ (unburdened) and a resulting annual savings of $\$ 116,621$, per the energy audits. These types of savings need to be captured by the Lab at the earliest possible opportunity regardless to what project financing strategy is eventually selected because lack of action results in tremendous lost opportunity costs. In the event that a performance-based contract is eventually put in place, low/no cost ECMs such as these are purely giveaways to the ESCOs.

RECOMMENDATION 3: Re-establish discussions with servicing utility(ies) regarding potential utility investment in energy-efficient equipment and systems. Based on discussions with Lab staff, it appears that the utility financing method may offer the path of least resistance as far as alternatively financed projects are concerned. However, there must be an interest on the part of the utility before this option may be considered. If a utility is interested in such an investment, the site should review potential projects to ensure the criteria established in the June 22, 1999 DOE general counsel memorandum (Section 3.3) can be satisfied. In addition, the utility may perform the design/build activities for BNL.

RECOMMENDATION 4: Consider the installation of GHPs via the DOE ground-source GHP technology-specific Super-ESPC. As noted in Section 4.2.3, the weather patterns and the water 
table at the Lab are particularly advantageous for the application of GHPs. In addition to offering increased operational efficiencies (and, thus, reduced operating costs), this type of application may offer an alternative option to the Lab in terms of its stated desire to expand the chilled water distribution system to service additional buildings. The point of contact for this contract is $\mathrm{Mr}$. Doug Culbreth of the DOE Atlanta Regional Office at (919) 782-5238. Once contacted, Mr. Culbreth can work with the site to recommend a method to assess the GHP ESPC project potential.

RECOMMENDATION 5: After the Section 6 issues have been resolved (recommendation 1 above) and after the potential alternative financing mechanisms have been evaluated (recommendations 3 and 4 above), the Lab should determine which, if any, of the alternative financing methods available best suit their needs. One way to go about this decision process is to use the document "Financing Energy Projects at Federal Facilities: A Screening Tool for Decision Making" (see Appendix I). This screening tool walks the reader through a seven-step decision process that allows the reader to incorporate issues and concerns particular to their site. The seven steps outlined below are presented in the guidance document:

1. Define the objectives: Identify goals to ensure objectives are met. In the case of BNL, these goals have been generally identified but require further resolution. More importantly, these objectives do not appear to have been consolidated between the many organizations involved.

2. Define criteria that influence the selection of the funding source: Why is the project/measure being considered? Mission requirements? Code compliance? Safety/health? Energy goals? Operations budgets? In some cases project funding via appropriations is easily justified on the basis of these criteria, making it inappropriate to consider as an energy-efficiency project. However, in the case of energy-efficiency projects, many of these criteria may be satisfied in addition to saving energy and money.

3. Determine the potential for energy savings: Much of this has already been done through the already completed audits. More detailed studies are not needed at this time. In the event the Lab does decide to pursue alternative financing, more detailed studies may be needed in the future, but that determination will need to be made once a procurement strategy has been established.

4. Define potential funding scenarios: Section 3 of this report outlines the funding scenarios to be considered.

5. Identify the site resources required to execute the various options: At this point, issues such as up-front funding to cover project development and contract management costs (Section 6.2) can be addressed.

6. Define the risks and benefits of the various scenarios: One example would be to assess the risks and benefits associated with various contract terms (Section 6.1). Union considerations (Section 6.3) should be addressed in the context of allowing contractor staff to perform O\&M and to what degree. Overall site incentives (Section 6.4) and benefits need to be weighed against tenant satisfaction and willingness to support. Conclusions drawn from these individual assessments may shape the Lab's willingness to use certain financing methods, as well as influence which measures the Lab is willing to install. Note that recommendation 1 advises that these issues be resolved as soon as possible and preferably prior to entering this decision methodology. It is expected that 
additional issues will be identified throughout the course of the project decision methodology process and these issues should be addressed as a part of the decision process.

7. Select an energy project financing method: In drawing together the conclusions developed in the preceding steps, the Lab will be able to justify its energy-efficiency procurement strategy. Once this decision is made, the Lab should proceed with project development and implementation.

RECOMMENDATION 6: As part of the on-going site operations process, the Lab should select life-cycle cost-effective energy-efficiency products when acquiring energy-using products. This can be accomplished by shopping for items with the ENERGY STAR ® label, as well as through the FEMP Procurement Challenge Program (see Section 3.5 for additional information).

RECOMMENDATION 7: Contact Mr. Bill Klebous of the DOE Philadelphia Regional Office (stationed in New York City) at (212) 264-0691. Mr. Klebous can assist the Lab in its decision process by answering questions regarding alternative financing and the application of, or participation in, other FEMP programs, such as the Procurement Challenge.

There are a number of potential paths available to the Lab that will achieve cost-effective energyefficiency improvements, as well as highly desired site infrastructure improvements. It is up to the Lab to assess these opportunities in terms of overall site operations inclusive of mission and infrastructure needs and priorities, organizational structures and interactions, funding availability and flexibility, and staff capabilities. Below are some examples of how the Lab might be able to package its energy-efficiency procurement strategy:

- Example Package 1: Obtain site funds to implement all ECMs with simple payback periods of less than, say, 1.5 years identified in the building energy audits; continue emphasis on utility procurement; implement process for site procurement of energy-using technologies by purchasing items with the ENERGY STAR ® label and per the specifications developed by the FEMP Procurement Challenge; and financing ECMs via utility project financing.

- Example Package 2: All measures listed in example package plus the installation of GHPs via the FEMP GHP technology-specific Super-ESPC. Note that care must always be exercised when considering more than one performance-based contract at a time on a single site because one project may affect the baseline or performance of equipment installed under another performance-based contract.

- Example Package 3: Obtain site funds to implement all ECMs with simple payback periods of less than, say, 1.5 years identified in the building energy audits; continue emphasis on utility procurement; implement process for site procurement of energy-using technologies by purchasing items with the ENERGY STAR (®) label and per the specifications developed by the FEMP Procurement Challenge; and financing of ECMs via FEMP regional Super-ESPC.

- Example Package 4: Obtain site funds to implement all ECMs with simple payback periods of less than, say, 1.5 years identified in the building energy audits; continued emphasis on utility procurement; implement process for site procurement of energy-using technologies by purchasing items with the ENERGY STAR ® label and per the specifications developed by the FEMP Procurement Challenge; and financing of ECMs via the FEMP GHP technologyspecific Super ESPC. 
- Example Package 5: Obtain site funds to implement all ECMs with simple payback periods of less than, say, 1.5 years identified in the building energy audits; continue emphasis on utility procurement; implement process for site procurement of energy using technologies by purchasing items with the ENERGY STAR $®$ label and per the specifications developed by the FEMP Procurement Challenge; and financing of ECMs via financing from the BPA.

There are a number of other potential "packages" that can be developed by using combinations of the various alternative financing methods, as shown in example package 2. Prior to developing a portfolio of actions, the Lab must first determine the availability of these methods, as noted in the recommendations above. Regardless of which procurement strategy is ultimately selected, including that of not seeking investment through alternative financing, the Lab should immediately implement a strategy to address the low/no cost ECMs identified in the audits per recommendation 2 above. The Lab should also initiate a site-wide program directed at the purchase of products with the ENERGY STAR @ label and per the specifications developed by the FEMP Procurement Challenge Program. 


\subsection{REFERENCES}

Carroll, D.M. 1999. “Financing Energy Projects at Federal Facilities.” PNNL-SA-30924. Pacific Northwest National Laboratory, Richland, Washington.

ESI. 1992. "Electrical Efficiency Improvement.” Energy Systems Institute, Auburn, Alabama.

Montgomery, D. 1984. “The Motor Rewind Issue: A New Look.” IEEE Transactions on Industry Applications. IA-20(5):1330-36.

R.S. Means Company. 1999. “2000 Means Cost Data”. R.S. Means, Co., Kingston, Massachusetts.

U.S. Department of Energy. 1996. "Measurement and Verification (M\&V) Guideline for Federal Energy Projects". DOE/GO-10096-248, U.S. Department of Energy, Washington, D.C. 


\section{APPENDIX A - ACRONYMS}

\begin{tabular}{|c|c|}
\hline 3PBP & Project Planning, Prioritization, Budgeting Process \\
\hline $\mathrm{A} / \mathrm{E}$ & Architect/engineering \\
\hline $\mathrm{AC}$ & Air conditioner \\
\hline ACEEE & American Council for Energy-Efficient Economy \\
\hline ALF & Alternate liquid fuels \\
\hline BNL & Brookhaven National Laboratory \\
\hline BPA & Bonneville Power Administration \\
\hline Btu & British thermal unit \\
\hline CAMP & Capital Asset Management Process \\
\hline CCWF & Central chilled water facility \\
\hline $\mathrm{CRO}$ & Department of Energy, Chicago Regional Office \\
\hline DDC & Direct digital controls \\
\hline DEMT & Departmental Energy Management Team \\
\hline DOE & Department of Energy \\
\hline DSM & Demand side management \\
\hline DT & Decatherm \\
\hline ECM & Energy conservation measure \\
\hline EPA & Environmental Protection Agency \\
\hline ER & Department of Energy, Office of Energy Research \\
\hline ESCO & Energy services contractor \\
\hline ESPC & Energy savings performance contract \\
\hline $\mathrm{F} \& \mathrm{O}$ & Facilities and Operations \\
\hline FEMP & Federal Energy Management Program \\
\hline FI & Department of Energy, Office of Field Integration \\
\hline FM & Department of Energy, Office of Facility Management \\
\hline FY & Fiscal year \\
\hline GHP & Ground-source heat pump \\
\hline GPP & General plant projects \\
\hline HQ & Department of Energy headquarters \\
\hline HVAC & Heating, ventilation, and air conditioning \\
\hline IDIQ & Indefinite Delivery, Indefinite Quantity contract \\
\hline IHEM & In-House Energy Management \\
\hline $\mathrm{kW}$ & Kilowatt \\
\hline $\mathrm{kWh}$ & Kilowatt•hour \\
\hline LIPA & Long Island Power Authority \\
\hline LPG & Liquid propane gas \\
\hline MBtu & Thousand British thermal units \\
\hline Mcf & Million cubic feet \\
\hline MCWO & Miscellaneous capital work order \\
\hline MMBtu & Million British thermal units \\
\hline MWh & Megawatt hour \\
\hline NYPA & New York Power Authority \\
\hline NYSERDA & New York State Energy Research and Development Authority \\
\hline $\mathrm{O} \& \mathrm{M}$ & Operations and maintenance \\
\hline PED & Plant Engineering Division \\
\hline PNNL & Pacific Northwest National Laboratory \\
\hline $\mathrm{R} \& \mathrm{D}$ & Research and development \\
\hline $\mathrm{SC}$ & Department of Energy, Office of Science \\
\hline $\operatorname{scfm}$ & Standard cubic feet per minute \\
\hline
\end{tabular}


SUNY

USC

VAV

VFD
State University of New York

United States Code

Variable air volume

Variable frequency drive 
APPENDIX B

\section{AGENDA FOR SITE VISIT}


Meeting Agenda

\section{Discussion of ESPC Application}

At

Brookhaven National Laboratory

May $4-7,1999$

May $4^{\text {th }}$

13:00-15:30 Building 134C - Conference Room

- Overview of BNL (M. Toscano)

- Overview of Site

U Utility Contracts

- Energy Management Efforts to Date

- Local Issues - Energy, Operations, Environmental

a Open Discussion

$\underline{15: 45-17: 00 \quad \text { Site Tour }}$

- General Site Tour

May $5^{\text {th }}$

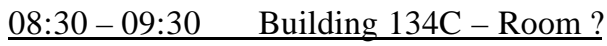

- Site Master Planning (J. DiNicola - Master Planner)

10:00-11:30 Building 134C $-\mathrm{A}$. Warren's Office

- Operations and Maintenance (A. Warren - Manager, O\&M)

$\underline{12: 00-13: 00 \quad \text { Lunch }}$

13:00 - 15:00 Building 134C - Conference Room

- Utility Contracts and Rate Structures - Detailed Discussion (M. Toscano)

- Energy Management at BNL

$\underline{15: 30-17: 00 \quad \text { Building 134C }- \text { Conference Room }}$

- ESPC Application @ BNL - Open Discussion (EMG) 


\title{
Meeting Agenda - Page 2
}

Discussion of ESPC Application at BNL

\begin{abstract}
$\operatorname{May} 6^{\text {th }}$
$\underline{\text { 08:30 - 10:00 Building 134C - Conference Room }}$
\end{abstract}

- DOE Site Representation (J. Eng: DOE- BHG)

$\underline{\text { 10:15 - 12:00 Building 134C - Conference Room }}$

- Site Facilities (E. Murphy - Manager, Plant Engineering)

12:00-13:00 Lunch

13:00 - 16:00 Site Visits

- Central Steam Facility

- Central Chilled Water Facility

- Selected Buildings (B. Pierce)

$\underline{\text { 16:00 }-17: 00 \quad \text { Building 134C }- \text { Conference Room }}$

- Recent Site Energy Surveys (M. Toscano/B. Pierce)

\author{
May $7^{\text {th }}$ \\ 09:00-09:30 Building 134C - Conference Room
}

- Contract and Procurement Office (T. Salvo)

09:30 - 10:30 Building 134C - M. Schaeffer's Office

- Contract and Procurement Office (M. Schaeffer)

$\underline{\text { 10:30 }-11: 30 \quad \text { Building } 134 \mathrm{C}-\text { Conference Room }}$

- Close-Out Discussion 


\section{APPENDIX C}

\section{BROOKHAVEN NATIONAL LABORATORY SITE MAP}

(http://www.bnl.gov/bnlweb/maps.html) 


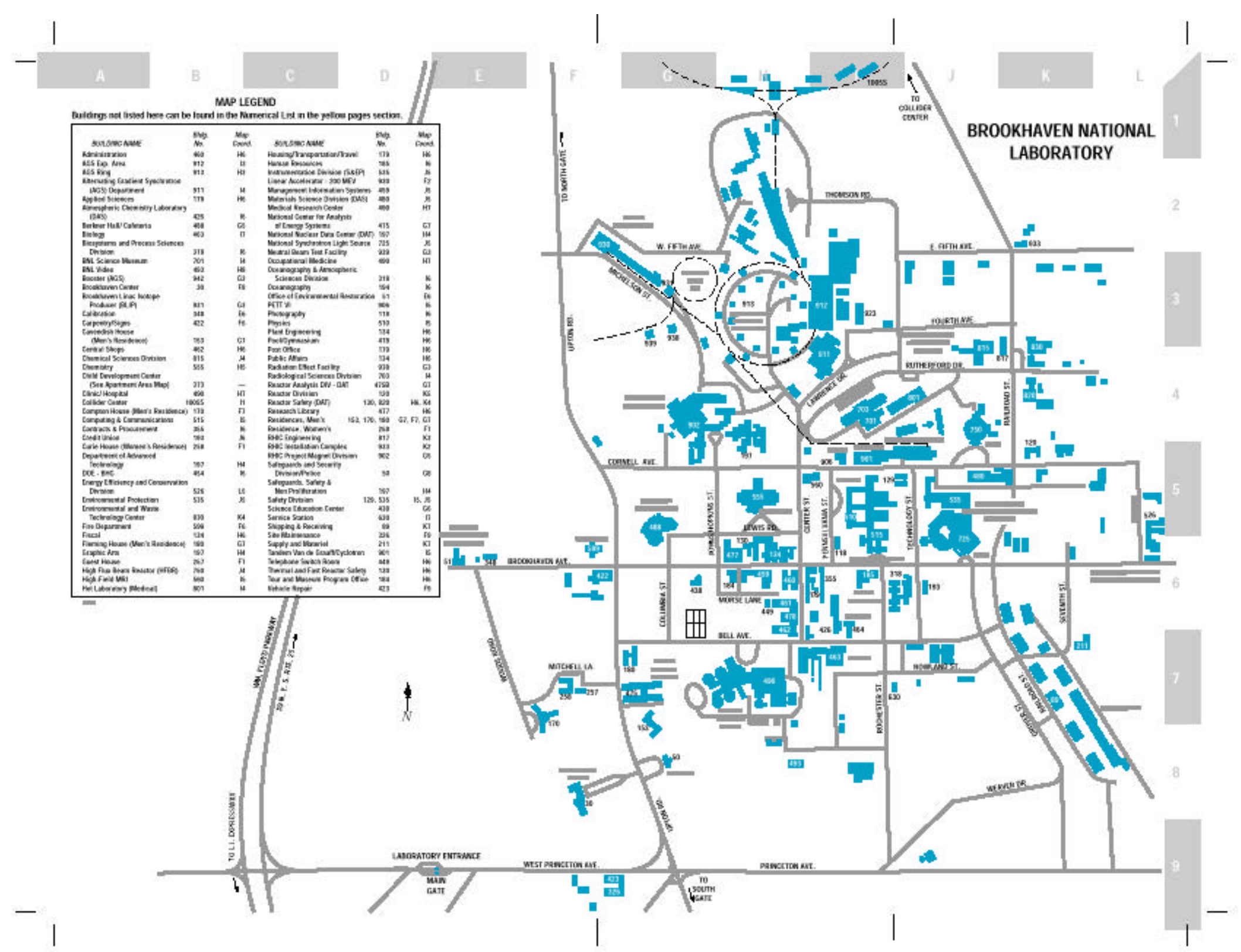


APPENDIX D

BROOKHAVEN NATIONAL LABORATORY

1997 PHYSICAL PLANT DATA SHEET 


\section{ORIGIN}

Former Camp Upton - WWI \& WWII

BNL started January 1, 1947

Operated by Associated Universities, Inc. POPULATION

\begin{tabular}{|c|c|c|}
\hline $\begin{array}{l}\text { Staff - } \\
\text { Other - } \\
\text { Total Average - }\end{array}$ & $\begin{array}{l}3,200 \\
\frac{320}{3,520}\end{array}$ & \\
\hline WEATHER & Degrees F & Degrees \\
\hline 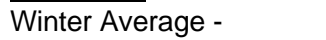 & $\overline{30.6}$ & -0.8 \\
\hline Summer Average - & 69.0 & $\begin{array}{l}20.6 \\
\text { Clearwe }\end{array}$ \\
\hline SITE & & \\
\hline $\begin{array}{l}\text { Total - } \\
\text { Built-up area - } \\
\text { Large machines - } \\
\text { Farm, housing, }\end{array}$ & $\begin{array}{l}5,321 \text { acre } \\
900 \text { acre } \\
400 \text { acre }\end{array}$ & $\begin{array}{l}2,153 \text { ha } \\
364 \text { ha } \\
162 \text { ha }\end{array}$ \\
\hline $\begin{array}{l}\text { sewage plant, etc. } \\
\text { Difference in elevations - } \\
\text { Max ht. above sea level - }\end{array}$ & $\begin{array}{l}200 \mathrm{acre} \\
80 \mathrm{ft} \\
120 \mathrm{ft}\end{array}$ & $\begin{array}{l}81 \mathrm{ha} \\
24 \mathrm{~m} \\
37 \mathrm{~m}\end{array}$ \\
\hline
\end{tabular}

Bounded by: Wes - William Floyd Parkway

South - Long Island Expressway

East - County Parks

North - Private Land

\section{BUILDINGS}

Buildings - 380

Trailers - 350

$4,199,187 \mathrm{sf}$

$116,617 \mathrm{sf}$

$390,117 \mathrm{~m} 2$

Other Structures - 27

\section{ROADS \& WALKS}

Roads - paved

- unpaved

Sidewalks -

Firebreaks -

Parking Slots -

Paved Areas -

\section{RAILROAD}

Tracks -

29 miles

14 miles

11 miles

46 miles

3,956 slots

83 acre

$10,834 \mathrm{~m} 2$

\section{FENCES}

Various Types -

1.7 miles

\section{ELECTRIC UTILITY}

LILCO Feeders, 2 @ -

Main Substations, @ - 603

Main Substation, @ 631 / 63

Dedicated Booster Transf,

Distribution Underground -

Demand, Max - to date

Use -

14 miles

$23 \mathrm{~km}$

$69 \mathrm{kV}$ ea.

$60,000 \mathrm{kVA}$

$80,000 \mathrm{kVA}$

20,000 kVA

$13.8 \mathrm{kV}$ and $2.4 \mathrm{kV}$

$54 \mathrm{MW}$ (73 MVA)

257,298,402 kWH/yr

\section{STEAM UTILITY}

\section{Boiler 1A}

Boiler 5

Boiler 6

Boiler 7

$\begin{array}{ll}45,000 \mathrm{lbs} / \mathrm{h} & 6 \mathrm{~kg} / \mathrm{s} \\ 180,000 \mathrm{lbs} / \mathrm{h} & 23 \mathrm{~kg} / \mathrm{s} \\ 125,000 \mathrm{lbs} / \mathrm{h} & 16 \mathrm{~kg} / \mathrm{s} \\ 125,000 \mathrm{lbs} / \mathrm{h} & 16 \mathrm{~kg} / \mathrm{s}\end{array}$

Fuel - \#2 oil, \#6 oil, and natural gas

Feed stocks - oil storage

Use -

- peak

$$
\begin{aligned}
& 2,345,000 \mathrm{gal} \\
& 600,000,000 \mathrm{lbs} / \mathrm{hr} \\
& 175,000 \mathrm{lbs} / \mathrm{h}
\end{aligned}
$$

BROOKHAVEN NATIONAL LABORATORY

997 PHYSICAL PLANT DATA SHEET

STEAM UTILITY (CONT'D)

Distribution - supply plus

condensate return $\quad 11$ miles $\quad 18 \mathrm{~km}$

$\begin{array}{lll}\text { Pressure - } & 125 \mathrm{psi} & 862 \mathrm{kPa}\end{array}$

WATER UTILITY

Treatment Plant Capacity - $6 \mathrm{mgd} \quad 263 \mathrm{~L} / \mathrm{s}$

Wells, $6 @$ -

Storage Tanks, 2 @ -

$1,200 \mathrm{gpm}$ e $\quad 76 \mathrm{~L} / \mathrm{s}$

350,000 gal $\quad 1,326,500 \mathrm{~L}$

$3,790,000 \mathrm{~L}$

Carbon Filters (Wells 10, 11 \& 12)-

(2 Packed Tower) Air Flow 11,250 scfm e 5,309 L/s

$250,000 \mathrm{gal} \quad 947,500$

$\begin{array}{lll} & 45 \text { miles } & 72 \mathrm{~km}\end{array}$

Pressure - $\quad 55$ to $70 \mathrm{psi} \quad 379$ to $483 \mathrm{kPa}$

\section{SANITARY UTILITY}

Waste Water Treatment Facility

Capacity

Use - summer

2.3 to $3.0 \mathrm{mgd}$

101 to $131 \mathrm{~L} / \mathrm{s}$

- normal

$1.2 \mathrm{mgd}$

$1.0 \mathrm{mgd}$

$0.8 \mathrm{mgd}$

- emergency storage I @ -

$2.8 \mathrm{mgd}$

$4.0 \mathrm{mgd}$

- emergency storage I @ -

19.7 miles

$52.6 \mathrm{~L} / \mathrm{s}$

$43.8 \mathrm{~L} / \mathrm{s}$

$35.1 \mathrm{~L} / \mathrm{s}$

$122.7 \mathrm{~L} / \mathrm{s}$

$175.3 \mathrm{~L} / \mathrm{s}$

Collection System Piping -

$32 \mathrm{~km}$

CHILLED WATER UTILITY

Centrifugal chillers, 3 @ -

Steam absorbtion chiller -

Three cell cooling tower -

Distribution System - supply

plus return pipe

Buildings served -

1,250 tons e $\quad 4,400 \mathrm{~kW}$

1,040 tons $\quad 3,661 \mathrm{~kW}$

$15,000 \mathrm{gpm} \quad 947 \mathrm{~L} / \mathrm{s}$

1.6 miles $\quad 2.6 \mathrm{~km}$

C.W. - storage

11

$3,000,000 \mathrm{gal}$

COMPRESSED AIR UTILITY

\begin{tabular}{lll}
\hline Compressors, 2 @ - & $750 \mathrm{scfm} \mathrm{e}$ & $354 \mathrm{~L} / \mathrm{s}$ \\
Pressure - & $125 \mathrm{psi}$ & $862 \mathrm{kPa}$ \\
Distribution System - & 1.6 miles & $2.6 \mathrm{~km}$
\end{tabular}

TELECOMMUNICATIONS UTILITY

$\begin{array}{ll}\text { Switch capacity - } & 7,025 \text { lines } \\ \text { Service - lines } & 5,986 \text { lines } \\ \text { - instruments } & 6,500 \text { approx. } \\ \text { - jacks } & 8,000 \text { approx. }\end{array}$

\section{STORM WATER SYSTEM}

Recharged to ground

SPDES Discharge Points - 7 points

Collection System - 9 miles

$14 \mathrm{~km}$

FIRE ALARM SYSTEM

Propriety System NFPA72 Style 7

Capacity -

20,000 points

- in service

4,700

\section{SECURITY ALARM SYSTEM}

Classified

$8,887,550 \mathrm{~L}$
$272,155,464 \mathrm{~kg} / \mathrm{yr}$
$22 \mathrm{~kg} / \mathrm{s}$

Datash97.As
WASTE DISPOSAL

Putrescibles \& Solid Waste -

Hazardous -

Recycled -
Town Landfill

On-site management \& collection for off-site disposal Paper, Cardboard, Bottles \& Cans FY 1997 Factbook 
APPENDIX E

DOE GENERAL COUNSEL MEMORANDUM ON THE RELATIONSHIP OF THE ANTI-DEFICIENCY ACT TO MULTI-YEAR CONTRACTS UNDER THE UTILITY INCENTIVE PROGRAM

AUTHORIZED UNDER SECTION 152(F) OF EPACT 


\section{Department of Energy}

Washington, DC 20585

June 22, 1999

MEMORANDUM FOR Shelley N. Fidler

Acting Director, Federal

Energy Management Program

FROM:

Mark S. Schwartz

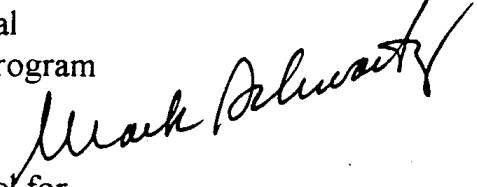

Deputy General Counsel for

Energy Policy

SUBJECT:

Relationship of the Anti-Deficiency Act to Multi-year Contracts

Under the Utility Incentive Program Authorized Under Section 152(f) of EPACT

\section{BACKGROUND}

The Department of Energy's (Department) Federal Energy Management Program (FEMP) is assisting federal agencies in improving energy and water efficiency to meet the goals of the Energy Policy Act of 1992 (EPACT), Pub. L. No. 102-486 (1992) (codified as amended in scattered sections of Title 42 of the U.S. Code) and Executive Order 13123. Because of the inability of Federal agencies to obtain appropriated funding for Federal building energy-efficiency and water conservation projects, one of the primary goals of FEMP is the implementation of the demand side management (DSM) and energy and water conservation and efficiency projects through utility services contracts and energy savings performance contracts. FEMP has requested our views as to whether and to what extent the authority provided to Federal agencies under section 152(f) of EPACT, which amends section 546 of the National Energy Conservation Policy Act, 42 U.S.C. 8256(c)(1997), is constrained by the Anti-Deficiency Act, 31 U.S.C. $\$ 1341$ (1998) and whether contracts under section 152(f) also qualify as "public utility services" contracts under section 201 of the Federal Property and Administrative Services Act of 1949, as amended (Federal Property Act), 40 U.S.C. §481(a)(3) (1997), which are eligible for a ten-year term.

FEMP's inquiry is directed to whether Federal agencies are required to obligate the entire contract amount, or amounts for termination costs, under DSM and energy and water conservation and efficiency contracts. This sort of obligational requirement would in FEMP's view negate the purpose of section $152(\mathrm{f}),{ }^{1}$ which is to make utility incentives available to federal

${ }^{1}$ Contracts under section 152(f) of EPACT are contracts with utilities under utility incentive programs (UIPs) offered by utilities. Each agency may accept any financial incentives, 
agencies on the same basis as they are available to other customers. The up to ten-year contract term available for "contracts for public utility services" under section 201 of the Federal Property Act is needed to make these projects economically viable.

\section{QUESTION}

You have requested our views on whether DSM and energy and water conservation and efficiency contracts entered into with utilities under section 152(f) of EPACT are "contracts for public utility services" under section 201 of the Federal Property Act, and thus can have both a ten-year contract term and an exemption from the full funding requirements of the AntiDeficiency Act, 31 U.S.C. $\$ 1341$ (1998).

\section{CONCLUSION}

DSM and energy and water conservation and efficiency contracts authorized by section 152(f) of EPACT can qualify as "contracts for public utility services" under section 201 of the Federal Property Act, if the services and goods provided meet the requirements for "utility services." As public utility service contracts they are not subject to the requirement that funds must be obligated for expenses (including potential termination costs) beyond the first year, and the contracts can have up to a ten-year term. In order to facilitate your implementation of this conclusion, we have prepared model agreements that reflect the kinds of energy conservation measures that we conclude are properly categorized as "public utility services."

\section{DISCUSSION}

Section 201(a)(3) of the Federal Property Act authorizes the General Services Administration (GSA) to enter into contracts for public utility services for periods not exceeding 10 years. It was enacted to effect economies in the procurement of such services. ${ }^{2}$ Use of section 201 presupposes the availability of a fiscal year appropriation for the first year and that the services to be rendered are merely incidental to the conduct of authorized government business.

Section 201(a) of the Federal Property Act provides, in part, as follows:

goods, or services "generally available to customers of such utility." Id. An agency, therefore, must satisfy "the criteria which generally apply to other customers" under a UIP. Finally, an amount equal to fifty percent of the agency's savings may be retained by the agency for additional energy efficiency measures. Id.

${ }^{2}$ GSA has delegated to DOE certain authority to enter into contracts for utility services for periods not to exceed ten-years. Delegation of Authority to the Secretary of Energy, signed by Brian K. Polly, Assistant Commissioner, Office of Procurement, Public Buildings Service, General Services Administration, dated February 12, 1987. See FAR §41.103(a)(3), 48 C.F.R. $\S 41.103(b)(1998)$ (referencing the delegation). 
The Administrator shall .... (3) procure and supply personal property and nonpersonal services for the use of executive agencies in the proper discharge of their responsibilities, and perform functions related to procurement and supply such as those mentioned above in subparagraph (1) of this subsection: Provided. That contracts for public utility services may be made for periods not exceeding ten years... .

Federal Property Act, $\S 201(a)(3)$ (emphasis added)

\section{A. What are "public utility services"?}

DSM and energy and water conservation and efficiency services are measures implemented or accomplished through specific projects intended and designed to achieve savings in the cost of energy and water, reduce demand for energy and water, and achieve energy efficiency improvements and water conservation. These measures are called Energy Conservation Measures (ECMs). The construction or installation of ECMs and other energy savings measures in government, commercial, industrial or residential dwellings is an important and integral part of planning and predicting power capacity needs in the future. While these contracts often involve the installation of equipment or refurbishing existing equipment, with a strong service component, these ECMs and similar efforts are extremely important to the modern utility as a valuable means of reducing or slowing the growth of demand for water, gas and electric services. These measures affect how much new capacity must be constructed or acquired and ultimately the cost of utility services to the rate payer. State public utility commissions have been encouraging utilities to reduce demand through energy conservation in order to reduce the cost involved in the construction or acquisition of new power capacity. ${ }^{3}$

The Federal Property Act does not provide a definition of "public utility services." The phrase is used in various states' laws, in the context of comprehensive regulation of the provision of public utility services. However, the term does not have a common definitive meaning:

\footnotetext{
${ }^{3}$ States, through statutes, regulations, and the actions of their public utility commissions, have been encouraging utilities to reduce demand through energy conservation in order to reduce the cost involved in the construction or acquisition of new power capacity. E.g., Indiana Admin. Code, Title 170. Indiana Utility Regulatory Comm., Art. 4, Rule 7, 6(b) (describing demand side management as a new source of utility supply); Texas Admin. Code, Title 16. Part II, chap. 23, subchapter D. \$23.31(a)(5) (requiring electric utilities to attempt to reduce total demand before applying for a cetificate for a new generating unit). EPACT included amendments to the Public Utility Regulatory Policies Act to ensure that utilities could regard investments in demand side management and energy conservation as equally profitable with investments in increased generating capacity. EPACT $\S 111$ (a), amending 16 U.S.C. $\$ 2621$; EPACT $\S 115$, amending 15 U.S.C. $\$ \$ 3202-03$. These developments both demonstrate that engaging in energy conservation and demand management have become viewed as a means of providing utility services to the public.
} 
"A 'public utility' has been described as a business organization which regularly supplies the public with some commodity or service, such as electricity, gas, water, transportation, or telephone or telegraph service. While the term has not been exactly defined, and as has been said, it would be difficult to construct a definition that would fit every conceivable case, the distinguishing characteristic of a public utility is the devotion of private property by the owner or person in control thereof to such a use that the public generally, or that part of the public which has been served and has accepted the service, has the right to demand that the use or services, as long as it is continued, shall be conducted with reasonable efficiency and under proper charges."

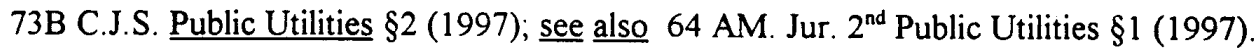

The General Accounting Office (GAO) has had few occasions to address the parameters of this phrase in the context of the Federal Property Act. GAO has declined to limit the definition of public utility to that used by a particular state:

The status of the Pipeline Company as a public utility under Title 42 of the Alaska Statutes is, in our opinion, doubtful. We are of this view because the company is not subject to regulatory control and because it has not served the public generally with natural gas. But the Congress has authorized long-term contracting in the case of services having public utility aspects. In doing so the Congress did not require that these public utility services be procured only from those firms which clearly come within the strict legal definition of a public utility. Perhaps in recognition of the legal imponderable involved in the application and enforcement of State laws regulating public utilities, and in view of the diversity of opinions between various jurisdictions respecting the legal character of public utilities, the Congress in its judgment determined to categorize the service rather than the contractor....

45 Comp Gen. 59, 64 (1965). "Thus, it is the nature of the product or service provided and not the nature of the provider of the product or services that may determine what are "public utility services." Moreover, GAO has indicated its view that the phrase "public utility services" should be interpreted broadly: "[T]he concept of what product or service constitutes a public utility service is not static for the purpose of statutory construction, but instead is flexible and adaptive, permitting statutes to be construed in light of the changes in technologies and methodologies for providing the product or service." 62 Comp. Gen. 569, 575 (1983).

We have concluded that the fact that ECM and DSM services involve transferring title to equipment does not defeat their character as "public utility services." 62 Comp. Gen. 569, 574 (1983). Where a contract was for the procurement of telephone equipment as well as telephone services, the Comptroller General decided that it was a contract for public utility services under section 201 of the Federal Property Act. The Comptroller General stated the following views on what are "public utility services": 
Further, while public utilities are generally described as providing services, we think that the concept of utility services can include the sale of a product or equipment as well as providing services in the literal sense.

Id. The Comptroller General concluded as follows:

On the basis of these fundamental premises, we think that the sale of telephone equipment or facilities with related services is a public utility type service just as much as leasing the equipment to the Government at a rental designed to recover the cost of the contractor's investment in facilities and equipment over the life of the rental agreement would be. The only difference between the two is that in the former case the Government acquires title to the system while in the latter, title remains with the utility. Thus the nature of service is virtually identical, and in any case, the difference is not so fundamental as to warrant its exclusion form the scope of transactions to which the authority of [section 201] applies.

Id. Even, however, if it is concluded that "qualified" DSM and ECM contracts entered into under section 152(f) of EPACT, standing alone, are not contracts to provide public utility services, these contracts would be contracts incidental to "contracts for public utility services." For instance, it has consistently been GSA's view that equipment provided with telephone services is incidental to those services:

It has been the position of GSA that the contracts which we enter into for telephone services are public utility services contracts regardless of whether the successful offeror was a tariffed carrier or an interconnect company. GSA has viewed the equipment involved in telecommunications procurement as incidental to the services. ....

GSA has historically regarded the equipment provided with telephone services as an incidental but necessary element of the services. Thus, we have always considered the acquisition of equipment as falling within the meaning of contracts for public utility services.

Whether the service is provided by utility-owned equipment or Governmentowned equipment does not change the nature of the services.

62 Comp. Gen. 569, 573-74 (1983).

Similarly, the equipment or products installed in federal buildings as DSMs or ECMs are necessary to reduce energy and water consumption, reduce the cost of energy and water and 
insure the adequate delivery of electric, gas, or water services and is incident to those services. The ability to plan, measure and reduce electric, gas and water consumption in the future is an important part of providing utility services. Moreover, reducing the long term cost of energy to the federal government was the specific reason why Congress included section 201 in the Federal Property Act. Therefore, so long as the dominant or primary purpose of the project is to reduce energy and water use or demand, and there is a direct connection between any equipment (or services) to be provided and achievement of the dominant or primary purpose, it should not matter whether the ECM or DSM activities include the provision of equipment, title to which
passes to the government.

In summary, contracts entered into under section 152(f) of EPACT may also be "contracts for public utility services" under section 201(a)(3) of the Federal Property Act.

\section{B. GSA's Views}

While the Secretary of Energy has the authority to develop guidelines to implement section 152(f) of EPACT, ${ }^{4}$ it is significant that GSA, the agency with primary responsibility and authority under section 201 of the Federal Property Act, has concluded in an opinion dated July 29, 1994 ("Exhibit A"), that certain DSM and ECM contracts entered into under section 152(f) of EPACT are contracts for "public utility services:"

In addition, GSA has authority under the Act to receive the goods and services contemplated under the proposed agreement with [the utility], including but not limited to, energy related equipment, its installation, and personnel training. 42 U.S.C. $\S 8256(\mathrm{c})(2)-(4) ; 40$ U.S.C. $\S 490(\mathrm{f})(7)(B)$.

The expenditure of the funds as contemplated by the proposed agreement with \{the utility\} is necessary for and incidental to compliance with the energy conservation requirements of the Act, 42 U.S.C. $\S 8253$. Therefore, this constitutes a necessary and proper expense for utility services. ...

Likewise, in accordance with 42 U.S.C. §8256(c)[Section 152(f) of EPACT], Congress specifically has authorized agencies to participate in utility incentive programs conducted by utilities and generally available to customers of such utilities. Participation in such programs will provide one of the means for GSA to satisfy the energy performance requirements for Federal buildings mandated by Congress in 42 U.S.C. $\$ 8253$. As explained above, the broad authority may be funded by GSA's Real Property Operations (BA-61) appropriations as necessary and proper expenses for utility services. ...

\footnotetext{
${ }^{4}$ Section 152(c) of EPACT provides the Secretary of Energy with the authority to
} develop "guidelines for the implementation" of the "Federal Energy Management" provisions of EPACT. 42 U.S.C. $\$ 8253(d)$ (1998) 
GSA Op. Off. Real Property Division, 3-4, July 29, 1994 (emphasis added).

Finally, GSA has negotiated and entered into a series of "areawide" contracts with utilities to provide electric, gas and gas transportation services to Federal agencies. ${ }^{5}$ In order to use an areawide contract any Federal agency in the defined geographic area simply has to execute an "authorization" agreement with the utility. The "areawide" contracts are entered into pursuant to GSA's "utility services" authority provided under section 201(a)(3) of the Federal Property Act. GSA now includes some DSM and ECM services under the areawide umbrella contracts. This is further evidence of GSA's view that DSM and ECM services may be "utility services" under section 201(a)(3).

C. What are the funding requirements for contracts for public utility services under section 201 of the Federal Property Act?

The Anti-Deficiency Act provides, in part, as follows:

An officer or employee of the United States Government or of the District of Columbia government may not-

(A) make or authorize an expenditure or obligation exceeding an amount available in an appropriation or fund for the expenditure or obligation;

(B) involve either government in a contract or obligation for the payment of money before an appropriation is made unless authorized by law....

31 U.S.C. $\S 1341$ (emphasis added). The Anti-Deficiency Act prohibits an executive agency from making expenditures or incurring obligations in excess of available appropriations, and from making a contract or obligation for the payment of money in advance of appropriations. Thus, as a general rule, the cost of a contract must be fully funded at the time the Government enters into the contract. The Anti-Deficiency Act, however, provides that Congress can authorize Federal agencies to "contractually" obligate the Government without the availability of an existing appropriation. "Contract authority" is statutory authority specifically authorizing "an agency to enter into a contract in excess of, or prior to, enactment of the applicable appropriation." See, G.A.O., Principles of Federal Appropriations Law, Vol. II, Ch. 6-51 (1992).

Section 201(a)(3) of the Federal Property Act has been interpreted to provide "contract authority." This provision has been interpreted as providing authority to enter into contracts for a term of ten-years without obligating funds for the total cost of the contract at the time the contract is entered into:

${ }^{5}$ See, e.g. Areawide Public Utility Contract for Electric, Natural Gas, Gas Transportation and Energy Management Services, Contract No. GS-00P-95-BSD-0008, between the United States of American and Public Service Company of New Mexico, August 23, 1995. 
The purpose of the proviso authorizing contracts for public utility services to be made for up to 10 years is to permit GSA to take advantage of discounts offered under long term contracts. If this provision is applicable, GSA need not have available to it budget authority to obligate the total estimated cost of the Centel contract but only sufficient budget authority to obligate its annual costs under the agreement.

As we have indicated above, GSA need not obligate the total estimated cost of the contract against the Fund, but only amounts necessary to cover it annual costs under the contract.

62 Comp. Gen. 569, 576 (1983) (emphasis added). Section 152(f) does not expressly provide authority to enter into ten-year contracts nor does it expressly provide an exception to the full funding requirements of the Anti-Deficiency Act. However, §152(f) contracts to the extent that they also constitute contracts for public utility services (under $\$ 201(a)(3)$ of the Federal Property Act) only require obligation of the annual costs under the contract during each year the contract is

\section{Qualified DSM Contracts}

Concerns have been raised that entering into DSMs, ECMs or other energy savings contracts with utilities of the type contemplated by $\S 152(\mathrm{f})$ of EPACT may in some cases result in providing goods and services that are not "utility services" under section 201 of the Federal Property Act. In order to alleviate these concerns and provide protections against misuse of the authority provided in section 152(f), we have concluded that only "qualified" DSM and ECM contracts will be designated "contracts for public utility services" under section 201 of the Federal Property Act. These qualifications will insure that the primary purpose of a DSM or ECM contract for "public utility services" will be to reduce energy and water cost and use.

These requirements or qualifications are reflected in the attached GSA Areawide Agreement (Exhibit B) and the draft Civilian Model Utility Agreement (Exhibit C). Included in the requirements for "qualified" DSM or ECM contracts are the following requirements:

(1) That the primary purpose of an ECM or DSM contract under section 152(f) must be to reduce the cost or use of energy and water and achieving greater energy efficiency [for example, DOE could not construct an entire new building to achieve or facilitate a programmatic objective under the guise of an ECM or DSM contract under section 152(f)];

(2) That general construction, training courses, and the purchase of supplies or equipment not directly related to an ECM or DSM is not permissible under section 152(f) of EPACT; 
(3) That energy or water savings must be sufficient to pay all costs under a DSM or ECM contract; and

(4) That ECMs or DSMs will not normally be used unless the net overall energy or water cost reduction can be demonstrated and verified.

Other restrictions and limitations on the use of ECM and DSM contracts are reflected in the attached model GSA Areawide contract and the Civilian Model Utility Agreement, which provide the necessary requirements and protections to "qualify" an ECM or DSM contract as a "contract for public utility services" under section 201 of the Federal Property Act. Proposed ECM or DSM contracts which contain terms or conditions that are materially different from those provided in Exhibits $C$ and $D$ create circumstances which require legal review by the Office of General Counsel.

\section{Concur:}
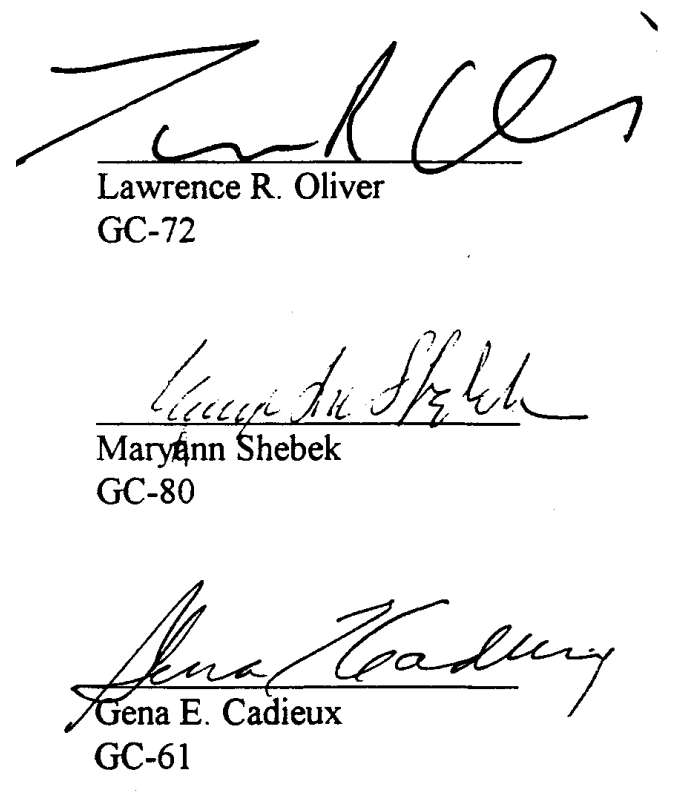

S/ Jolunfferrick

SEE ATTACHMENT

John A. Herrick

Chief Counsel

Golden Field Office 
APPENDIX F

AUDIT IDENTIFIED ENERGY-EFFICIENCY PROJECT LIST 


\begin{tabular}{cl}
$\begin{array}{c}\text { Building } \\
\text { Number }\end{array}$ & $\begin{array}{l}\text { Measure } \\
\text { Category }\end{array}$ \\
30 & HVAC Control \\
30 & HVAC Control \\
30 & Water Heating \\
30 & Lighting \\
30 & Lighting \\
30 & Other \\
30 & Recommendations \\
30 & Lighting \\
30 & HVAC Equipment \\
30 & Lighting \\
51 & Lighting \\
51 & HVAC Control \\
51 & Water Heating \\
120 & Lighting \\
120 & Other \\
120 & Wecommendations \\
120 & Lighting \\
129 & HVAC Control \\
129 & Water Heating \\
129 & Water Heating \\
129 & Lighting \\
& \\
\hline 30 & \\
30 &
\end{tabular}

\begin{tabular}{|c|c|}
\hline Measure & $\begin{array}{c}\text { Cost: } \\
\text { material }\end{array}$ \\
\hline $\begin{array}{l}\text { Change HVAC setpoint } \\
\text { temps. }\end{array}$ & $\$ 0$ \\
\hline $\begin{array}{l}\text { Install programmable } \\
\text { thermostats }\end{array}$ & $\$ 450$ \\
\hline $\begin{array}{l}\text { Reduce DHW temp. } \\
\text { setpoint }\end{array}$ & $\$ 0$ \\
\hline IR sensors in bathrooms & $\$ 150$ \\
\hline $\begin{array}{l}\text { Replace incandescent } \mathrm{w} / \\
\text { CFL }\end{array}$ & $\$ 900$ \\
\hline Install insulation under roof & $\$ 4,202$ \\
\hline $\begin{array}{l}\text { Install steam cycle control } \\
\text { system }\end{array}$ & $\$ 4,000$ \\
\hline $\begin{array}{l}\text { Use higher efficiency } \\
\text { lamps }\end{array}$ & $\$ 42$ \\
\hline $\begin{array}{l}\text { Install energy efficient oil } \\
\text { burner }\end{array}$ & $\$ 4,553$ \\
\hline $\begin{array}{l}\text { Install T-8 lamps and } \\
\text { electronic ballasts }\end{array}$ & $\$ 1,898$ \\
\hline $\begin{array}{l}\text { Install T-8 lamps and } \\
\text { electronic ballasts }\end{array}$ & $\$ 5,602$ \\
\hline $\begin{array}{l}\text { Install hot water reset } \\
\text { controls on heating boiler }\end{array}$ & $\$ 840$ \\
\hline Insulate DHW tank & $\$ 26$ \\
\hline Install occupancy sensors & $\$ 75$ \\
\hline Weatherstrip windows & $\$ 228$ \\
\hline Insulate DHW tank & $\$ 17$ \\
\hline $\begin{array}{l}\text { Install T-8 lamps and } \\
\text { electronic ballasts }\end{array}$ & $\$ 7,017$ \\
\hline $\begin{array}{l}\text { Change HVAC setpoint } \\
\text { temps. }\end{array}$ & $\$ 0$ \\
\hline $\begin{array}{l}\text { Install low flow faucet } \\
\text { aerators }\end{array}$ & $\$ 10$ \\
\hline Insulate DHW tank & $\$ 17$ \\
\hline $\begin{array}{l}\text { Install T-8 lamps and } \\
\text { electronic ballasts }\end{array}$ & $\$ 11,33$ \\
\hline
\end{tabular}

$\begin{array}{ccc}\begin{array}{c}\text { Cost labor } \\ \text { (includes } \\ \text { disposal costs) }\end{array} & \begin{array}{c}\text { Total } \\ \text { Cost }\end{array} & \begin{array}{c}\text { Total Annual } \\ \text { Energy Savings: } \\ \text { (MMBtu/yr) }\end{array} \\ \$ 10 & \$ 10 & 116.30 \\ \$ 270 & \$ 720 & 115.31 \\ \$ 5 & \$ 5 & 0.15 \\ \$ 90 & \$ 240 & 6.22 \\ \$ 162 & \$ 1,062 & 10.05 \\ & \$ 4,202 & 164.78 \\ & \$ 4,000 & 148.12 \\ \$ 50 & \$ 92 & 0.59 \\ \$ 603 & \$ 5,156 & 179.62 \\ \$ 619 & \$ 2,517 & 12.99 \\ \$ 1,958 & \$ 7,560 & 46.36 \\ \$ 90 & \$ 930 & 29.96 \\ \$ 90 & \$ 116 & 0.62 \\ \$ 45 & \$ 120 & 1.97 \\ \$ 1,767 & \$ 1,995 & 18.69 \\ \$ 50 & \$ 67 & 0.35 \\ \$ 2,290 & \$ 9,307 & 46.31 \\ \$ 127 & \$ 127 & 47.24 \\ \$ 45 & \$ 55 & 5.08 \\ \$ 50 & \$ 67 & 0.81 \\ \$ 4,467 & \$ 15,804 & 73.57 \\ & & \\ & & \\ & & \end{array}$

Annual Cost

Saving:

Annual Cost

Total Annual

Savings: O\&M Cost Savings

Simple

$\$ 632$

$\$ 0$

$\$ 632$

$\$ 467$

$\$ 0$

$\$ 467$

0.0

$\$ 3$

$\$ 0$

$$
\$ 3
$$

$\$ 142$

$\$ 229$

$\$ 0$

$\$ 142$

$\$ 650$

$\$ 73$

$\$ 302$

$\$ 650$

$\$ 584$

$\$ 13$

$\$ 0$

$\$ 584$

$\$ 708$

$\$ 13$ 


\begin{tabular}{|c|c|c|c|c|c|c|c|c|c|c|}
\hline $\begin{array}{l}\text { Building } \\
\text { Number }\end{array}$ & $\begin{array}{l}\text { Measure } \\
\text { Category }\end{array}$ & Measure & $\begin{array}{c}\text { Cost: } \\
\text { materials }\end{array}$ & $\begin{array}{l}\text { Cost labor } \\
\text { (includes } \\
\text { disposal costs) }\end{array}$ & $\begin{array}{l}\text { Total } \\
\text { Cost }\end{array}$ & $\begin{array}{l}\text { Total Annual } \\
\text { Energy Savings: } \\
\text { (MMBtu/yr) }\end{array}$ & $\begin{array}{l}\text { Annual Cost } \\
\text { Savings: } \\
\text { Energy }\end{array}$ & $\begin{array}{c}\text { Annual Cost } \\
\text { Savings: O\&M }\end{array}$ & $\begin{array}{l}\text { Total Annual } \\
\text { Cost Savings }\end{array}$ & $\begin{array}{r}\text { Simple } \\
\text { Payback }\end{array}$ \\
\hline 130 & $\begin{array}{l}\text { Other } \\
\text { Recommendations }\end{array}$ & $\begin{array}{l}\text { Caulk leaky through-the- } \\
\text { wall heat pump sleeves }\end{array}$ & $\$ 432$ & & $\$ 432$ & 7.73 & $\$ 176$ & $\$ 0$ & $\$ 176$ & 2.5 \\
\hline 130 & $\begin{array}{l}\text { Other } \\
\text { Recommendations }\end{array}$ & $\begin{array}{l}\text { Install insulation under } \\
\text { floor }\end{array}$ & $\$ 8,584$ & $\$ 0$ & $\$ 8,584$ & 41.22 & $\$ 940$ & $\$ 0$ & $\$ 940$ & 9.1 \\
\hline 130 & Lighting & IR sensors in bathrooms & $\$ 150$ & $\$ 90$ & $\$ 240$ & 1.06 & $\$ 24$ & $\$ 0$ & $\$ 24$ & 10.0 \\
\hline 130 & Lighting & $\begin{array}{l}\text { Install T-8 lamps and } \\
\text { electronic ballasts }\end{array}$ & $\$ 10,238$ & $\$ 3,341$ & $\$ 13,579$ & 39.75 & $\$ 906$ & $\$ 0$ & $\$ 906$ & 15.0 \\
\hline 134 & $\begin{array}{l}\text { Other } \\
\text { Recommendations }\end{array}$ & $\begin{array}{l}\text { Clean A/C evaporator and } \\
\text { condenser coils }\end{array}$ & $\$ 0$ & $\$ 90$ & $\$ 90$ & 4.08 & $\$ 93$ & $\$ 0$ & $\$ 93$ & 1.0 \\
\hline 134 & HVAC Equipment & $\begin{array}{l}\text { Test for and replace faulty } \\
\text { steam traps }\end{array}$ & $\$ 2,400$ & $\$ 1,125$ & $\$ 3,525$ & 0.57 & $\$ 2,806$ & $\$ 0$ & $\$ 2,806$ & 1.3 \\
\hline 134 & Lighting & Install occupancy sensors & $\$ 689$ & $\$ 495$ & $\$ 1,184$ & 7.45 & $\$ 170$ & $\$ 0$ & $\$ 170$ & 7.0 \\
\hline 134 & Motors & Install motor controls & $\$ 3,526$ & $\$ 720$ & $\$ 4,246$ & 26.02 & $\$ 593$ & $\$ 0$ & $\$ 593$ & 7.2 \\
\hline 134 & Lighting & $\begin{array}{l}\text { InstallT-8 lamps and } \\
\text { electronic ballasts }\end{array}$ & $\$ 11,089$ & $\$ 5,445$ & $\$ 16,534$ & 77.10 & $\$ 1,758$ & $\$ 0$ & $\$ 1,758$ & 9.4 \\
\hline 153 & Water Heating & $\begin{array}{l}\text { Rreduce DHW temp. } \\
\text { setpoint }\end{array}$ & $\$ 0$ & $\$ 20$ & $\$ 20$ & 103.46 & $\$ 534$ & $\$ 0$ & $\$ 534$ & 0.0 \\
\hline 153 & Water Heating & $\begin{array}{l}\text { Install low flow } \\
\text { showerheads }\end{array}$ & $\$ 240$ & $\$ 270$ & $\$ 510$ & 171.36 & $\$ 885$ & $\$ 0$ & $\$ 885$ & 0.6 \\
\hline 153 & Lighting & $\begin{array}{l}\text { Install T-8 lamps and } \\
\text { electronic ballasts }\end{array}$ & $\$ 3,975$ & $\$ 1,346$ & $\$ 5,321$ & 103.51 & $\$ 2,359$ & $\$ 0$ & $\$ 2,359$ & 2.3 \\
\hline 153 & Lighting & $\begin{array}{l}\text { Replace incandescent w/ } \\
\text { CFL }\end{array}$ & $\$ 5,100$ & $\$ 918$ & $\$ 6,018$ & 40.30 & $\$ 919$ & $\$ 729$ & $\$ 1,648$ & 3.7 \\
\hline 153 & Lighting & IR sensors in kitchen & $\$ 600$ & $\$ 360$ & $\$ 960$ & 8.83 & $\$ 201$ & $\$ 0$ & $\$ 201$ & 4.8 \\
\hline 153 & $\begin{array}{l}\text { Other } \\
\text { Recommendations }\end{array}$ & $\begin{array}{l}\text { Install insulation under } \\
\text { floor }\end{array}$ & $\$ 11,934$ & & $\$ 11,934$ & 83.17 & $\$ 1,896$ & $\$ 0$ & $\$ 1,896$ & 6.3 \\
\hline 153 & $\begin{array}{l}\text { Other } \\
\text { Recommendations }\end{array}$ & $\begin{array}{l}\text { Install insulation in attic } \\
\text { floor }\end{array}$ & $\$ 9,180$ & & $\$ 9,180$ & 58.49 & $\$ 1,333$ & $\$ 0$ & $\$ 1,333$ & 6.9 \\
\hline 153 & Water Heating & Install solar DHW system & $\$ 12,626$ & $\$ 5,000$ & $\$ 17,626$ & 206.08 & $\$ 1,064$ & $\$ 40$ & $\$ 1,104$ & 16.0 \\
\hline
\end{tabular}




\begin{tabular}{|c|c|c|c|c|c|c|c|c|c|c|}
\hline $\begin{array}{l}\text { Building } \\
\text { Number }\end{array}$ & $\begin{array}{l}\text { Measure } \\
\text { Category }\end{array}$ & Measure & $\begin{array}{c}\text { Cost: } \\
\text { materials }\end{array}$ & $\begin{array}{l}\text { Cost labor } \\
\text { (includes } \\
\text { disposal costs) }\end{array}$ & $\begin{array}{l}\text { Total } \\
\text { Cost }\end{array}$ & $\begin{array}{l}\text { Total Annual } \\
\text { Energy Savings: } \\
\text { (MMBtu/yr) }\end{array}$ & $\begin{array}{l}\text { Annual Cost } \\
\text { Savings: } \\
\text { Energy }\end{array}$ & $\begin{array}{c}\text { Annual Cost } \\
\text { Savings: O\&M }\end{array}$ & $\begin{array}{l}\text { Total Annual } \\
\text { Cost Savings }\end{array}$ & $\begin{array}{c}\text { Simple } \\
\text { Payback }\end{array}$ \\
\hline 170 & Water Heating & $\begin{array}{l}\text { Reduce DHW temp. } \\
\text { setpoint }\end{array}$ & $\$ 0$ & $\$ 5$ & $\$ 5$ & 78.96 & $\$ 407$ & $\$ 0$ & $\$ 407$ & 0.0 \\
\hline 170 & Water Heating & $\begin{array}{l}\text { Install low flow } \\
\text { showerheads }\end{array}$ & $\$ 500$ & & $\$ 500$ & 128.10 & $\$ 661$ & $\$ 0$ & $\$ 661$ & 0.8 \\
\hline 170 & Lighting & $\begin{array}{l}\text { Install T-8 lamps and } \\
\text { electronic ballasts }\end{array}$ & $\$ 684$ & $\$ 252$ & $\$ 936$ & 22.12 & $\$ 504$ & $\$ 0$ & $\$ 504$ & 1.9 \\
\hline 170 & Lighting & $\begin{array}{l}\text { Replace incandescent w/ } \\
\text { CFL }\end{array}$ & $\$ 2,671$ & $\$ 508$ & $\$ 3,179$ & 31.50 & $\$ 718$ & $\$ 580$ & $\$ 1,298$ & 2.4 \\
\hline 170 & Lighting & Install occupancy sensors & $\$ 300$ & $\$ 180$ & $\$ 480$ & 6.28 & $\$ 143$ & $\$ 0$ & $\$ 143$ & 3.4 \\
\hline 170 & $\begin{array}{l}\text { Other } \\
\text { Recommendations }\end{array}$ & $\begin{array}{l}\text { Install insulation under } \\
\text { floor }\end{array}$ & $\$ 12,943$ & & $\$ 12,943$ & 56.09 & $\$ 1,279$ & $\$ 0$ & $\$ 1,279$ & 10.1 \\
\hline 170 & Water Heating & Install solar DHW system & $\$ 6,980$ & $\$ 9,380$ & $\$ 16,360$ & 189.42 & $\$ 978$ & $\$ 0$ & $\$ 978$ & 16.7 \\
\hline 180 & Water Heating & $\begin{array}{l}\text { Reduce DHW temp. } \\
\text { setpoint }\end{array}$ & $\$ 0$ & $\$ 14$ & $\$ 14$ & 107.10 & $\$ 553$ & $\$ 0$ & $\$ 553$ & 0.0 \\
\hline 180 & Water Heating & $\begin{array}{l}\text { Install low flow } \\
\text { showerheads }\end{array}$ & $\$ 650$ & & $\$ 650$ & 100.66 & $\$ 519$ & $\$ 0$ & $\$ 519$ & 1.3 \\
\hline 180 & Lighting & $\begin{array}{l}\text { Replace incandescent w/ } \\
\text { CFL }\end{array}$ & $\$ 3,270$ & $\$ 589$ & $\$ 3,859$ & 35.41 & $\$ 808$ & $\$ 640$ & $\$ 1,448$ & 2.7 \\
\hline 180 & $\begin{array}{l}\text { Other } \\
\text { Recommendations }\end{array}$ & Install insulation under roof & $\$ 2,886$ & $\$ 2,886$ & $\$ 5,772$ & 32.11 & $\$ 732$ & $\$ 0$ & $\$ 732$ & 7.9 \\
\hline 180 & Water Heating & Install solar DHW system & $\$ 17,454$ & & $\$ 17,454$ & 257.88 & $\$ 981$ & $\$ 0$ & $\$ 981$ & 17.8 \\
\hline 185 & HVAC Control & $\begin{array}{l}\text { Change HVAC setpoint } \\
\text { temp. }\end{array}$ & $\$ 0$ & $\$ 70$ & $\$ 70$ & 13.15 & $\$ 446$ & $\$ 0$ & $\$ 446$ & 0.2 \\
\hline 185 & Water Heating & $\begin{array}{l}\text { Install low flow faucet } \\
\text { aerators }\end{array}$ & $\$ 12$ & $\$ 27$ & $\$ 39$ & 2.28 & $\$ 52$ & $\$ 0$ & $\$ 52$ & 0.8 \\
\hline 185 & Water Heating & $\begin{array}{l}\text { Reduce DHW temp. } \\
\text { setpoint }\end{array}$ & $\$ 0$ & $\$ 5$ & $\$ 5$ & 0.18 & $\$ 4$ & $\$ 0$ & $\$ 4$ & 1.3 \\
\hline 185 & Lighting & Install occupancy sensors & $\$ 75$ & $\$ 45$ & $\$ 120$ & 1.23 & $\$ 28$ & $\$ 0$ & $\$ 28$ & 4.3 \\
\hline 185 & Water Heating & Insulate DHW tank & $\$ 40$ & $\$ 100$ & $\$ 140$ & 0.75 & $\$ 17$ & $\$ 0$ & $\$ 17$ & 8.2 \\
\hline 185 & Lighting & $\begin{array}{l}\text { Install T-8 lamps and } \\
\text { electronic ballasts }\end{array}$ & $\$ 6,925$ & $\$ 2,390$ & $\$ 9,315$ & 49.00 & $\$ 1,117$ & $\$ 0$ & $\$ 1,117$ & 8.3 \\
\hline 193 & Lighting & Install occupancy sensors & $\$ 225$ & $\$ 135$ & $\$ 360$ & 2.47 & $\$ 56$ & $\$ 0$ & $\$ 56$ & 6.4 \\
\hline 193 & Water Heating & Insulate DHW tank & $\$ 17$ & $\$ 50$ & $\$ 67$ & 0.35 & $\$ 8$ & $\$ 0$ & $\$ 8$ & 8.4 \\
\hline 193 & Lighting & $\begin{array}{l}\text { Install T- } 8 \text { lamps and } \\
\text { electronic ballasts }\end{array}$ & $\$ 2,471$ & $\$ 806$ & $\$ 3,277$ & 16.31 & $\$ 372$ & $\$ 0$ & $\$ 372$ & 8.8 \\
\hline
\end{tabular}




\begin{tabular}{|c|c|c|c|c|c|c|c|c|c|c|}
\hline $\begin{array}{l}\text { Building } \\
\text { Number }\end{array}$ & $\begin{array}{l}\text { Measure } \\
\text { Category }\end{array}$ & Measure & $\begin{array}{c}\text { Cost: } \\
\text { materials }\end{array}$ & $\begin{array}{l}\text { Cost labor } \\
\text { (includes } \\
\text { disposal costs) }\end{array}$ & $\begin{array}{l}\text { Total } \\
\text { Cost }\end{array}$ & $\begin{array}{l}\text { Total Annual } \\
\text { Energy Savings: } \\
\text { (MMBtu/yr) }\end{array}$ & $\begin{array}{l}\text { Annual Cost } \\
\text { Savings: } \\
\text { Energy }\end{array}$ & $\begin{array}{c}\text { Annual Cost } \\
\text { Savings: O\&M }\end{array}$ & $\begin{array}{l}\text { Total Annual } \\
\text { Cost Savings }\end{array}$ & $\begin{array}{r}\text { Simple } \\
\text { Payback }\end{array}$ \\
\hline 194 & Water Heating & $\begin{array}{l}\text { Reduce DHW temp. } \\
\text { setpoint }\end{array}$ & $\$ 0$ & $\$ 9$ & $\$ 9$ & 1.75 & $\$ 40$ & $\$ 0$ & $\$ 40$ & 0.2 \\
\hline 194 & Lighting & $\begin{array}{l}\text { Replace incandescent w/ } \\
\text { CFL }\end{array}$ & $\$ 20$ & $\$ 5$ & $\$ 25$ & 0.29 & $\$ 7$ & $\$ 7$ & $\$ 14$ & 1.8 \\
\hline 194 & Water Heating & Insulate DHW tank & $\$ 40$ & $\$ 100$ & $\$ 140$ & 1.48 & $\$ 34$ & $\$ 0$ & $\$ 34$ & 4.1 \\
\hline 194 & Lighting & $\begin{array}{l}\text { Install T-8 lamps and } \\
\text { electronic ballasts }\end{array}$ & $\$ 1,869$ & $\$ 749$ & $\$ 2,618$ & 20.74 & $\$ 473$ & $\$ 0$ & $\$ 473$ & 5.5 \\
\hline 194 & $\begin{array}{l}\text { Other } \\
\text { Recommendations }\end{array}$ & Install insulation in walls & $\$ 17,600$ & & $\$ 17,600$ & 21.07 & $\$ 1,907$ & $\$ 0$ & $\$ 1,907$ & 9.2 \\
\hline 244 & Water Heating & $\begin{array}{l}\text { Reduce DHW temp. } \\
\text { setpoint }\end{array}$ & $\$ 0$ & $\$ 5$ & $\$ 5$ & 1.18 & $\$ 27$ & $\$ 0$ & $\$ 27$ & 0.2 \\
\hline 244 & HVAC Control & $\begin{array}{l}\text { Install programmable } \\
\text { thermostats }\end{array}$ & $\$ 975$ & $\$ 585$ & $\$ 1,560$ & 364.59 & $\$ 1,696$ & $\$ 0$ & $\$ 1,696$ & 0.9 \\
\hline 244 & Lighting & $\begin{array}{l}\text { Install T-8 lamps, } \\
\text { electronic ballasts and } \\
\text { controls }\end{array}$ & $\$ 371$ & $\$ 162$ & $\$ 533$ & 5.54 & $\$ 126$ & $\$ 0$ & $\$ 126$ & 4.2 \\
\hline 244 & HVAC Control & $\begin{array}{l}\text { Install steam cycle control } \\
\text { system }\end{array}$ & $\$ 4,000$ & & $\$ 4,000$ & 145.60 & $\$ 574$ & $\$ 0$ & $\$ 574$ & 7.0 \\
\hline 244 & HVAC Equipment & $\begin{array}{l}\text { Install energy efficient oil } \\
\text { burner }\end{array}$ & $\$ 4,267$ & $\$ 565$ & $\$ 4,832$ & 142.24 & $\$ 561$ & $\$ 0$ & $\$ 561$ & 8.6 \\
\hline 244 & Lighting & $\begin{array}{l}\text { Install T-8 lamps and } \\
\text { electronic ballasts }\end{array}$ & $\$ 5,472$ & $\$ 1,786$ & $\$ 7,258$ & 24.52 & $\$ 559$ & $\$ 0$ & $\$ 559$ & 13.0 \\
\hline 257 & Water Heating & $\begin{array}{l}\text { Reduce DHW temp. } \\
\text { setpoint }\end{array}$ & $\$ 0$ & $\$ 5$ & $\$ 5$ & 54.32 & $\$ 281$ & $\$ 0$ & $\$ 281$ & 0.0 \\
\hline 257 & Lighting & $\begin{array}{l}\text { Replace incandescent w/ } \\
\text { CFL }\end{array}$ & $\$ 1,230$ & $\$ 221$ & $\$ 1,451$ & 17.21 & $\$ 482$ & $\$ 392$ & $\$ 874$ & 1.7 \\
\hline 257 & Water Heating & $\begin{array}{l}\text { Install low flow } \\
\text { showerheads }\end{array}$ & $\$ 650$ & & $\$ 650$ & 58.66 & $\$ 303$ & $\$ 0$ & $\$ 303$ & 2.1 \\
\hline 257 & Lighting & $\begin{array}{l}\text { Replace with } 13 \text { - } 28 \mathrm{~W} \\
\text { Comp Fluor / Modular }\end{array}$ & $\$ 396$ & $\$ 70$ & $\$ 466$ & 7.41 & $\$ 169$ & $\$ 32$ & $\$ 201$ & 2.3 \\
\hline 257 & Lighting & $\begin{array}{l}\text { Install T-8 lamps and } \\
\text { electronic ballasts }\end{array}$ & $\$ 108$ & $\$ 56$ & $\$ 164$ & 1.32 & $\$ 30$ & $\$ 0$ & $\$ 30$ & 5.5 \\
\hline 257 & $\begin{array}{l}\text { Other } \\
\text { Recommendations }\end{array}$ & $\begin{array}{l}\text { Install insulation under } \\
\text { floor }\end{array}$ & $\$ 3,852$ & & $\$ 3,852$ & 29.51 & $\$ 673$ & $\$ 0$ & $\$ 673$ & 5.7 \\
\hline 257 & Water Heating & Install solar DHW system & $\$ 8,930$ & & $\$ 8,930$ & 93.52 & $\$ 483$ & $\$ 0$ & $\$ 483$ & 18.5 \\
\hline
\end{tabular}




\begin{tabular}{|c|c|c|c|c|c|c|c|c|c|c|}
\hline $\begin{array}{l}\text { Building } \\
\text { Number }\end{array}$ & $\begin{array}{l}\text { Measure } \\
\text { Category }\end{array}$ & Measure & $\begin{array}{c}\text { Cost: } \\
\text { materials }\end{array}$ & $\begin{array}{l}\text { Cost labor } \\
\text { (includes } \\
\text { disposal costs) }\end{array}$ & $\begin{array}{l}\text { Total } \\
\text { Cost }\end{array}$ & $\begin{array}{l}\text { Total Annual } \\
\text { Energy Savings: } \\
\text { (MMBtu/yr) }\end{array}$ & $\begin{array}{l}\text { Annual Cost } \\
\text { Savings: } \\
\text { Energy }\end{array}$ & $\begin{array}{l}\text { Annual Cost } \\
\text { Savings: O\&M }\end{array}$ & $\begin{array}{l}\text { Total Annual } \\
\text { Cost Savings }\end{array}$ & $\begin{array}{r}\text { Simple } \\
\text { Payback }\end{array}$ \\
\hline 258 & Water Heating & $\begin{array}{l}\text { Reduce DHW temp. } \\
\text { setpoint }\end{array}$ & $\$ 0$ & 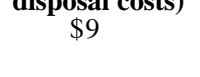 & $\$ 9$ & 48.16 & $\$ 249$ & $\$ 0$ & $\$ 249$ & 0.0 \\
\hline 258 & Water Heating & $\begin{array}{l}\text { Install low flow } \\
\text { showerheads }\end{array}$ & $\$ 600$ & & $\$ 600$ & 62.16 & $\$ 321$ & $\$ 0$ & $\$ 321$ & 1.9 \\
\hline 258 & Lighting & $\begin{array}{l}\text { Replace incandescent w/ } \\
\text { CFL }\end{array}$ & $\$ 2,640$ & $\$ 475$ & $\$ 3,115$ & 40.76 & $\$ 929$ & $\$ 668$ & $\$ 1,597$ & 2.0 \\
\hline 258 & Lighting & $\begin{array}{l}\text { Install T-8 lamps and } \\
\text { electronic ballasts }\end{array}$ & $\$ 215$ & $\$ 70$ & $\$ 285$ & 4.07 & $\$ 93$ & $\$ 0$ & $\$ 93$ & 3.1 \\
\hline 258 & $\begin{array}{l}\text { Other } \\
\text { Recommendations }\end{array}$ & $\begin{array}{l}\text { Install insulation under } \\
\text { floor }\end{array}$ & $\$ 8,970$ & & $\$ 8,970$ & 70.85 & $\$ 1,615$ & $\$ 0$ & $\$ 1,615$ & 5.6 \\
\hline 258 & Lighting & $\begin{array}{l}\text { Replace with } 6 \text { - } 35 \text { watt } \\
\text { high pressure sodium }\end{array}$ & $\$ 720$ & $\$ 338$ & $\$ 1,058$ & 4.14 & $\$ 94$ & $\$ 87$ & $\$ 181$ & 5.8 \\
\hline 258 & Lighting & Install occupancy sensors & $\$ 300$ & $\$ 180$ & $\$ 480$ & 3.44 & $\$ 79$ & $\$ 0$ & $\$ 79$ & 6.1 \\
\hline 258 & Water Heating & Install solar DHW system & $\$ 10,430$ & & $\$ 10,430$ & 99.54 & $\$ 514$ & $\$ 0$ & $\$ 514$ & 20.3 \\
\hline 326 & HVAC Control & $\begin{array}{l}\text { Change HVAC setpoint } \\
\text { temps. }\end{array}$ & $\$ 0$ & $\$ 150$ & $\$ 150$ & 6.02 & $\$ 1,128$ & $\$ 0$ & $\$ 1,128$ & 0.1 \\
\hline 326 & Water Heating & $\begin{array}{l}\text { Install low flow faucet } \\
\text { aerators }\end{array}$ & $\$ 8$ & $\$ 50$ & $\$ 58$ & 4.98 & $\$ 114$ & $\$ 0$ & $\$ 114$ & 0.5 \\
\hline 326 & Water Heating & $\begin{array}{l}\text { Install low flow } \\
\text { showerheads }\end{array}$ & $\$ 30$ & $\$ 84$ & $\$ 114$ & 5.38 & $\$ 123$ & $\$ 0$ & $\$ 123$ & 0.9 \\
\hline 326 & Lighting & $\begin{array}{l}\text { Replace incandescent w/ } \\
\text { CFL }\end{array}$ & $\$ 59$ & $\$ 25$ & $\$ 84$ & 0.87 & $\$ 20$ & $\$ 22$ & $\$ 42$ & 2.0 \\
\hline 326 & $\begin{array}{l}\text { Other } \\
\text { Recommendations }\end{array}$ & Install insulation under roof & $\$ 9,591$ & $\$ 0$ & $\$ 9,591$ & 20.10 & $\$ 1,542$ & $\$ 0$ & $\$ 1,542$ & 6.2 \\
\hline 326 & Lighting & $\begin{array}{l}\text { Install T- } 8 \text { lamps and } \\
\text { electronic ballasts }\end{array}$ & $\$ 44$ & $\$ 17$ & $\$ 61$ & 0.29 & $\$ 7$ & $\$ 0$ & $\$ 7$ & 8.7 \\
\hline 326 & Water Heating & Insulate DHW tank & $\$ 23$ & $\$ 90$ & $\$ 113$ & 0.54 & $\$ 12$ & $\$ 0$ & $\$ 12$ & 9.4 \\
\hline 355 & HVAC Control & $\begin{array}{l}\text { Change HVAC setpoint } \\
\text { temps. }\end{array}$ & $\$ 0$ & $\$ 100$ & $\$ 100$ & 38.99 & $\$ 918$ & $\$ 0$ & $\$ 918$ & 0.1 \\
\hline 355 & Water Heating & $\begin{array}{l}\text { Reduce DHW temp. } \\
\text { setpoint }\end{array}$ & $\$ 0$ & $\$ 5$ & $\$ 5$ & 0.36 & $\$ 8$ & $\$ 0$ & $\$ 8$ & 0.6 \\
\hline 355 & Lighting & $\begin{array}{l}\text { Install T-8 lamps, } \\
\text { electronic ballasts and } \\
\text { controls }\end{array}$ & $\$ 119$ & $\$ 59$ & $\$ 178$ & 1.57 & $\$ 36$ & $\$ 0$ & $\$ 36$ & 4.9 \\
\hline 355 & Lighting & $\begin{array}{l}\text { Install T-8 lamps and } \\
\text { electronic ballasts }\end{array}$ & $\$ 11,069$ & $\$ 3,571$ & $\$ 14,640$ & 72.23 & $\$ 1,647$ & $\$ 0$ & $\$ 1,647$ & 8.9 \\
\hline
\end{tabular}




\begin{tabular}{|c|c|c|c|c|c|c|c|c|c|c|}
\hline $\begin{array}{l}\text { Building } \\
\text { Number }\end{array}$ & $\begin{array}{l}\text { Measure } \\
\text { Category }\end{array}$ & Measure & $\begin{array}{c}\text { Cost: } \\
\text { materials }\end{array}$ & $\begin{array}{l}\text { Cost labor } \\
\text { (includes } \\
\text { disposal costs) }\end{array}$ & $\begin{array}{l}\text { Total } \\
\text { Cost }\end{array}$ & $\begin{array}{l}\text { Total Annual } \\
\text { Energy Savings: }\end{array}$ & $\begin{array}{l}\text { Annual Cost } \\
\text { Savings: } \\
\text { Energy }\end{array}$ & $\begin{array}{c}\text { Annual Cost } \\
\text { Savings: O\&M }\end{array}$ & $\begin{array}{l}\text { Total Annual } \\
\text { Cost Savings }\end{array}$ & $\begin{array}{c}\text { Simple } \\
\text { Payback }\end{array}$ \\
\hline 423 & HVAC Control & $\begin{array}{l}\text { Install programmable } \\
\text { thermostats }\end{array}$ & $\$ 600$ & $\$ 360$ & $\$ 960$ & 936.10 & $\$ 3,696$ & $\$ 0$ & $\$ 3,696$ & 0.3 \\
\hline 423 & Water Heating & $\begin{array}{l}\text { Reduce DHW temp. } \\
\text { setpoint }\end{array}$ & $\$ 0$ & $\$ 5$ & $\$ 5$ & 0.15 & $\$ 3$ & $\$ 0$ & $\$ 3$ & 1.7 \\
\hline 423 & HVAC Control & $\begin{array}{l}\text { Install steam cycle control } \\
\text { system }\end{array}$ & $\$ 4,000$ & & $\$ 4,000$ & 256.90 & $\$ 1,012$ & $\$ 0$ & $\$ 1,012$ & 4.0 \\
\hline 423 & HVAC Equipment & $\begin{array}{l}\text { Install energy efficient oil } \\
\text { burner }\end{array}$ & $\$ 8,537$ & $\$ 1,130$ & $\$ 9,667$ & 268.38 & $\$ 1,058$ & $\$ 0$ & $\$ 1,058$ & 9.1 \\
\hline 423 & Lighting & $\begin{array}{l}\text { Install T-8 lamps and } \\
\text { electronic ballasts }\end{array}$ & $\$ 3,053$ & $\$ 994$ & $\$ 4,047$ & 19.32 & $\$ 440$ & $\$ 0$ & $\$ 440$ & 9.2 \\
\hline 423 & $\begin{array}{l}\text { Other } \\
\text { Recommendations }\end{array}$ & Install insulation under roof & $\$ 16,970$ & & $\$ 16,970$ & 393.74 & $\$ 1,563$ & $\$ 0$ & $\$ 1,563$ & 10.9 \\
\hline 426 & Water Heating & $\begin{array}{l}\text { Reduce DHW temp. } \\
\text { setpoint }\end{array}$ & $\$ 0$ & $\$ 5$ & $\$ 5$ & 0.76 & $\$ 17$ & $\$ 0$ & $\$ 17$ & 0.3 \\
\hline 426 & Lighting & Install occupancy sensors & $\$ 75$ & $\$ 45$ & $\$ 120$ & 0.99 & $\$ 22$ & $\$ 0$ & $\$ 22$ & 5.5 \\
\hline 426 & HVAC Equipment & $\begin{array}{l}\text { Install down draft ceiling } \\
\text { fans }\end{array}$ & $\$ 400$ & $\$ 400$ & $\$ 800$ & -3.80 & $\$ 97$ & $\$ 0$ & $\$ 97$ & 8.2 \\
\hline 426 & Lighting & $\begin{array}{l}\text { Install T-8 lamps and } \\
\text { electronic ballasts }\end{array}$ & $\$ 6,014$ & $\$ 2,164$ & $\$ 8,178$ & 42.95 & $\$ 979$ & $\$ 0$ & $\$ 979$ & 8.4 \\
\hline 452 & Lighting & $\begin{array}{l}\text { Reduced ouput lamps, } \\
\text { ballasts and reflectors }\end{array}$ & $\$ 541$ & $\$ 86$ & $\$ 627$ & 7.92 & $\$ 180$ & $\$ 0$ & $\$ 180$ & 3.5 \\
\hline 452 & $\begin{array}{l}\text { Other } \\
\text { Recommendations }\end{array}$ & $\begin{array}{l}\text { Install vinyl strip door in } \\
\text { stock room }\end{array}$ & $\$ 650$ & $\$ 550$ & $\$ 1,200$ & 0.06 & $\$ 299$ & $\$ 0$ & $\$ 299$ & 4.0 \\
\hline 452 & Lighting & $\begin{array}{l}\text { Install T-8 lamps and } \\
\text { electronic ballasts }\end{array}$ & $\$ 13,451$ & $\$ 4,788$ & $\$ 18,239$ & 118.36 & $\$ 2,698$ & $\$ 0$ & $\$ 2,698$ & 6.8 \\
\hline 452 & $\begin{array}{l}\text { Other } \\
\text { Recommendations }\end{array}$ & Install insulation under roof & $\$ 22,232$ & $\$ 0$ & $\$ 22,232$ & 0.57 & $\$ 2,780$ & $\$ 0$ & $\$ 2,780$ & 8.0 \\
\hline 459 & Lighting & Install occupancy sensors & $\$ 150$ & $\$ 90$ & $\$ 240$ & 7.21 & $\$ 164$ & $\$ 0$ & $\$ 164$ & 1.5 \\
\hline 459 & Motors & $\begin{array}{l}\text { Install high efficiency } \\
\text { motors }\end{array}$ & $\$ 1,614$ & $\$ 608$ & $\$ 2,222$ & 19.82 & $\$ 452$ & $\$ 0$ & $\$ 452$ & 4.9 \\
\hline 459 & Lighting & $\begin{array}{l}\text { Install T- } 8 \text { lamps and } \\
\text { electronic ballasts }\end{array}$ & $\$ 11,918$ & $\$ 4,313$ & $\$ 16,231$ & 114.28 & $\$ 2,605$ & $\$ 0$ & $\$ 2,605$ & 6.2 \\
\hline 459 & Water Heating & Insulate DHW tank & $\$ 17$ & $\$ 77$ & $\$ 94$ & 0.49 & $\$ 11$ & $\$ 0$ & $\$ 11$ & 8.5 \\
\hline 460 & HVAC Control & $\begin{array}{l}\text { Change HVAC setpoint } \\
\text { temp. }\end{array}$ & $\$ 0$ & $\$ 9$ & $\$ 9$ & 14.17 & $\$ 382$ & $\$ 0$ & $\$ 382$ & 0.0 \\
\hline 460 & Lighting & Install occupancy sensors & $\$ 150$ & $\$ 90$ & $\$ 240$ & 3.04 & $\$ 69$ & $\$ 0$ & $\$ 69$ & 3.5 \\
\hline 460 & Lighting & $\begin{array}{l}\text { Install T- } 8 \text { lamps and } \\
\text { electronic ballasts }\end{array}$ & $\$ 11,348$ & $\$ 4,313$ & $\$ 15,661$ & 103.91 & $\$ 2,369$ & $\$ 0$ & $\$ 2,369$ & 6.6 \\
\hline
\end{tabular}




\begin{tabular}{|c|c|c|c|c|c|c|c|c|c|c|}
\hline $\begin{array}{l}\text { Building } \\
\text { Number }\end{array}$ & $\begin{array}{l}\text { Measure } \\
\text { Category }\end{array}$ & Measure & $\begin{array}{c}\text { Cost: } \\
\text { materials }\end{array}$ & $\begin{array}{l}\text { Cost labor } \\
\text { (includes } \\
\text { disposal costs) }\end{array}$ & $\begin{array}{l}\text { Total } \\
\text { Cost }\end{array}$ & $\begin{array}{l}\text { Total Annual } \\
\text { Energy Savings: } \\
\text { (MMBtu/yr) }\end{array}$ & $\begin{array}{l}\text { Annual Cost } \\
\text { Savings: } \\
\text { Energy }\end{array}$ & $\begin{array}{c}\text { Annual Cost } \\
\text { Savings: O\&M }\end{array}$ & $\begin{array}{l}\text { Total Annual } \\
\text { Cost Savings }\end{array}$ & $\begin{array}{c}\text { Simple } \\
\text { Payback }\end{array}$ \\
\hline 461 & Water Heating & $\begin{array}{l}\text { Reduce DHW temp. } \\
\text { setpoint }\end{array}$ & $\$ 0$ & $\$ 5$ & $\$ 5$ & 0.01 & $\$ 34$ & $\$ 0$ & $\$ 34$ & 0.1 \\
\hline 461 & Lighting & $\begin{array}{l}\text { Replace incandescent w/ } \\
\text { CFL }\end{array}$ & $\$ 30$ & $\$ 5$ & $\$ 35$ & 0.66 & $\$ 15$ & $\$ 12$ & $\$ 27$ & 1.3 \\
\hline 461 & Lighting & $\begin{array}{l}\text { Install more efficient exit } \\
\text { signs }\end{array}$ & $\$ 140$ & $\$ 90$ & $\$ 230$ & 3.47 & $\$ 79$ & $\$ 49$ & $\$ 128$ & 1.8 \\
\hline 461 & Lighting & $\begin{array}{l}\text { Install T-8 lamps and } \\
\text { electronic ballasts }\end{array}$ & $\$ 1,682$ & $\$ 659$ & $\$ 2,341$ & 20.54 & $\$ 468$ & $\$ 0$ & $\$ 468$ & 5.0 \\
\hline 462 & HVAC Equipment & Install ceiling fans & $\$ 800$ & & $\$ 800$ & -3.45 & $\$ 314$ & $\$ 0$ & $\$ 314$ & 2.5 \\
\hline 462 & Lighting & $\begin{array}{l}\text { Install T-8 lamps and } \\
\text { electronic ballasts }\end{array}$ & $\$ 6,292$ & $\$ 2,549$ & $\$ 8,841$ & 76.07 & $\$ 1,734$ & $\$ 0$ & $\$ 1,734$ & 5.1 \\
\hline 462 & Motors & $\begin{array}{l}\text { Install high efficiency } \\
\text { motors }\end{array}$ & $\$ 313$ & $\$ 202$ & $\$ 515$ & 2.52 & $\$ 57$ & $\$ 0$ & $\$ 57$ & 9.0 \\
\hline 463 & $\begin{array}{l}\text { Other } \\
\text { Recommendations }\end{array}$ & Reduce fume hood air flow & & & $\$ 31,000$ & $1,077.03$ & $\$ 23,000$ & & $\$ 23,000$ & 1.3 \\
\hline 463 & HVAC Control & Reduce supply air flow & & & $\$ 44,000$ & 511.93 & $\$ 9,319$ & & $\$ 9,319$ & 4.7 \\
\hline 463 & Lighting & $\begin{array}{l}\text { Install T-8 lamps and } \\
\text { electronic ballasts }\end{array}$ & & & $\$ 141,000$ & 563.15 & $\$ 17,000$ & & $\$ 17,000$ & 8.3 \\
\hline 463 & HVAC Equipment & $\begin{array}{l}\text { Install VFD on supply fan } \\
\text { SF-1 }\end{array}$ & & & $\$ 42,000$ & 254.55 & $\$ 5,000$ & & $\$ 5,000$ & 8.4 \\
\hline 463 & HVAC Equipment & $\begin{array}{l}\text { Convert office area from } \\
\text { constant vol to VAV }\end{array}$ & & & $\$ 41,000$ & 198.20 & $\$ 2,531$ & & $\$ 2,531$ & 16.2 \\
\hline 464 & Lighting & Install occupancy sensors & $\$ 75$ & $\$ 45$ & $\$ 120$ & 9.77 & $\$ 223$ & $\$ 0$ & $\$ 223$ & 0.5 \\
\hline 464 & $\begin{array}{l}\text { Other } \\
\text { Recommendations }\end{array}$ & $\begin{array}{l}\text { Clean } \mathrm{A} / \mathrm{C} \text { evaporator and } \\
\text { condenser coils }\end{array}$ & $\$ 0$ & $\$ 100$ & $\$ 100$ & 7.02 & $\$ 160$ & $\$ 0$ & $\$ 160$ & 0.6 \\
\hline 464 & HVAC Control & $\begin{array}{l}\text { Install programmable } \\
\text { thermostats }\end{array}$ & $\$ 150$ & $\$ 90$ & $\$ 240$ & 4.73 & $\$ 108$ & $\$ 0$ & $\$ 108$ & 2.2 \\
\hline 464 & Lighting & $\begin{array}{l}\text { Install T-8 lamps and } \\
\text { electronic ballasts }\end{array}$ & $\$ 7,142$ & $\$ 2,606$ & $\$ 9,748$ & 58.94 & $\$ 1,343$ & $\$ 0$ & $\$ 1,343$ & 7.3 \\
\hline 475 & Water Heating & $\begin{array}{l}\text { Reduce DHW temp. } \\
\text { setpoint }\end{array}$ & $\$ 0$ & $\$ 5$ & $\$ 5$ & 0.19 & $\$ 4$ & $\$ 0$ & $\$ 4$ & 1.3 \\
\hline 475 & Lighting & Install occupancy sensors & $\$ 300$ & $\$ 180$ & $\$ 480$ & 5.33 & $\$ 121$ & $\$ 0$ & $\$ 121$ & 4.0 \\
\hline 475 & Lighting & $\begin{array}{l}\text { Install T-8 lamps and } \\
\text { electronic ballasts }\end{array}$ & $\$ 12,268$ & $\$ 4,003$ & $\$ 16,271$ & 80.97 & $\$ 1,846$ & $\$ 0$ & $\$ 1,846$ & 8.8 \\
\hline 475 & $\begin{array}{l}\text { Other } \\
\text { Recommendations }\end{array}$ & Weatherstrip windows & $\$ 1,080$ & $\$ 8,370$ & $\$ 9,450$ & 44.88 & $\$ 1,023$ & $\$ 0$ & $\$ 1,023$ & 9.2 \\
\hline
\end{tabular}




\begin{tabular}{|c|c|c|c|c|c|c|c|c|c|c|}
\hline $\begin{array}{l}\text { Building } \\
\text { Number }\end{array}$ & $\begin{array}{l}\text { Measure } \\
\text { Category }\end{array}$ & Measure & $\begin{array}{c}\text { Cost: } \\
\text { materials }\end{array}$ & $\begin{array}{c}\text { Cost labor } \\
\text { (includes } \\
\text { disposal costs) }\end{array}$ & $\begin{array}{l}\text { Total } \\
\text { Cost }\end{array}$ & $\begin{array}{l}\text { Total Annual } \\
\text { Energy Savings: } \\
\text { (MMBtu/yr) }\end{array}$ & $\begin{array}{l}\text { Annual Cost } \\
\text { Savings: } \\
\text { Energy }\end{array}$ & $\begin{array}{l}\text { Annual Cost } \\
\text { Savings: O\&M }\end{array}$ & $\begin{array}{l}\text { Total Annual } \\
\text { Cost Savings }\end{array}$ & $\begin{array}{l}\text { Simple } \\
\text { Payback }\end{array}$ \\
\hline 477 & HVAC Control & $\begin{array}{l}\text { Change HVAC setpoint } \\
\text { temps. }\end{array}$ & $\$ 0$ & $\$ 9$ & $\$ 9$ & 15.46 & $\$ 757^{\circ}$ & $\$ 0$ & $\$ 757$ & 0.0 \\
\hline 477 & Water Heating & $\begin{array}{l}\text { Reduce DHW temp. } \\
\text { setpoint }\end{array}$ & $\$ 0$ & $\$ 5$ & $\$ 5$ & 0.22 & $\$ 5$ & $\$ 0$ & $\$ 5$ & 1.0 \\
\hline 477 & Lighting & Install occupancy sensors & $\$ 225$ & $\$ 135$ & $\$ 360$ & 7.59 & $\$ 173$ & $\$ 0$ & $\$ 173$ & 2.1 \\
\hline 477 & Lighting & $\begin{array}{l}\text { Install T-8 lamps and } \\
\text { electronic ballasts }\end{array}$ & $\$ 15,534$ & $\$ 5,069$ & $\$ 20,603$ & 175.19 & $\$ 3,994$ & $\$ 0$ & $\$ 3,994$ & 5.2 \\
\hline 477 & Motors & $\begin{array}{l}\text { Install high efficiency } \\
\text { motors }\end{array}$ & $\$ 420$ & $\$ 202$ & $\$ 622$ & 2.00 & $\$ 46$ & $\$ 0$ & $\$ 46$ & 13.5 \\
\hline 478 & HVAC Control & $\begin{array}{l}\text { Change HVAC setpoint } \\
\text { temps. }\end{array}$ & $\$ 0$ & $\$ 5$ & $\$ 5$ & 0.11 & $\$ 536$ & $\$ 0$ & $\$ 536$ & 0.0 \\
\hline 478 & Water Heating & $\begin{array}{l}\text { Reduce DHW temp. } \\
\text { setpoint }\end{array}$ & $\$ 0$ & $\$ 5$ & $\$ 5$ & 0.01 & $\$ 31$ & $\$ 0$ & $\$ 31$ & 0.2 \\
\hline 478 & Lighting & $\begin{array}{l}\text { Replace incandescent w/ } \\
\text { CFL }\end{array}$ & $\$ 60$ & $\$ 11$ & $\$ 71$ & 1.61 & $\$ 37$ & $\$ 29$ & $\$ 66$ & 1.1 \\
\hline 478 & $\begin{array}{l}\text { Other } \\
\text { Recommendations }\end{array}$ & $\begin{array}{l}\text { Install automatic pool } \\
\text { cover system }\end{array}$ & $\$ 25,000$ & $\$ 0$ & $\$ 25,000$ & 0.70 & $\$ 3,438$ & $\$ 0$ & $\$ 3,438$ & 7.3 \\
\hline 478 & Lighting & $\begin{array}{l}\text { Install T-8 lamps and } \\
\text { electronic ballasts }\end{array}$ & $\$ 662$ & $\$ 216$ & $\$ 878$ & 4.89 & $\$ 112$ & $\$ 0$ & $\$ 112$ & 7.8 \\
\hline 479 & HVAC Control & $\begin{array}{l}\text { Install programmable } \\
\text { thermostats }\end{array}$ & $\$ 900$ & $\$ 540$ & $\$ 1,440$ & 0.52 & $\$ 2,558$ & $\$ 0$ & $\$ 2,558$ & 0.6 \\
\hline 479 & HVAC Equipment & $\begin{array}{l}\text { Test for and replace faulty } \\
\text { steam traps }\end{array}$ & $\$ 900$ & $\$ 868$ & $\$ 1,768$ & 0.25 & $\$ 1,203$ & $\$ 0$ & $\$ 1,203$ & 1.5 \\
\hline 479 & Lighting & $\begin{array}{l}\text { Reduced output lamps, } \\
\text { ballasts and rreflectors }\end{array}$ & $\$ 6,488$ & $\$ 1,339$ & $\$ 7,827$ & 142.48 & $\$ 3,248$ & $\$ 0$ & $\$ 3,248$ & 2.4 \\
\hline 479 & HVAC Equipment & $\begin{array}{l}\text { Install ceiling fans in high } \\
\text { bay areas }\end{array}$ & $\$ 3,200$ & & $\$ 3,200$ & 0.25 & $\$ 814$ & $\$ 0$ & $\$ 814$ & 3.9 \\
\hline 479 & Lighting & $\begin{array}{l}\text { Install T-8 lamps and } \\
\text { electronic ballasts }\end{array}$ & $\$ 4,320$ & $\$ 1,620$ & $\$ 5,940$ & 64.77 & $\$ 1,476$ & $\$ 0$ & $\$ 1,476$ & 4.0 \\
\hline 480 & HVAC Control & $\begin{array}{l}\text { Change HVAC setpoint } \\
\text { temp. }\end{array}$ & $\$ 0$ & $\$ 81$ & $\$ 81$ & 46.28 & $\$ 1,253$ & $\$ 0$ & $\$ 1,253$ & 0.1 \\
\hline 480 & HVAC Equipment & $\begin{array}{l}\text { Install down draft ceiling } \\
\text { fans in high bay areas }\end{array}$ & $\$ 400$ & $\$ 400$ & $\$ 800$ & -3.77 & $\$ 296$ & $\$ 0$ & $\$ 296$ & 2.7 \\
\hline 480 & Lighting & $\begin{array}{l}\text { Replace incandescent w/ } \\
\text { CFL }\end{array}$ & $\$ 368$ & $\$ 59$ & $\$ 427$ & 4.74 & $\$ 107$ & $\$ 38$ & $\$ 145$ & 2.9 \\
\hline 480 & Lighting & $\begin{array}{l}\text { Install T-8 lamps and } \\
\text { electronic ballasts }\end{array}$ & $\$ 21,387$ & $\$ 7,236$ & $\$ 28,623$ & 184.10 & $\$ 4,197$ & $\$ 0$ & $\$ 4,197$ & 6.8 \\
\hline
\end{tabular}




\begin{tabular}{|c|c|c|c|}
\hline $\begin{array}{l}\text { Building } \\
\text { Number }\end{array}$ & $\begin{array}{l}\text { Measure } \\
\text { Category }\end{array}$ & Measure & $\begin{array}{c}\text { Cost: } \\
\text { materials }\end{array}$ \\
\hline 488 & HVAC Control & $\begin{array}{l}\text { Change HVAC setpoint } \\
\text { temp. }\end{array}$ & $\$ 0$ \\
\hline 488 & Water Heating & $\begin{array}{l}\text { Reduce DHW temp. } \\
\text { setpoint }\end{array}$ & $\$ 0$ \\
\hline 488 & Lighting & $\begin{array}{l}\text { Replace incandescent w/ } \\
\text { CFL }\end{array}$ & $\$ 5,275$ \\
\hline 488 & $\begin{array}{l}\text { Other } \\
\text { Recommendations }\end{array}$ & $\begin{array}{l}\text { Install high efficiency } \\
\text { evaporator fans }\end{array}$ & $\$ 205$ \\
\hline 488 & Motors & $\begin{array}{l}\text { Install high efficiency } \\
\text { motors }\end{array}$ & $\$ 1,299$ \\
\hline 488 & $\begin{array}{l}\text { Other } \\
\text { Recommendations }\end{array}$ & $\begin{array}{l}\text { Install vinyl strip door on } \\
\text { loading dock }\end{array}$ & $\$ 325$ \\
\hline 488 & Motors & Install motor controls & $\$ 5,026$ \\
\hline 488 & Water Heating & Insulate DHW tank & $\$ 29$ \\
\hline 488 & Lighting & $\begin{array}{l}\text { Install T-8 lamps and } \\
\text { electronic ballasts }\end{array}$ & $\$ 6,072$ \\
\hline 490 & Water Heating & $\begin{array}{l}\text { Reduce DHW temp. } \\
\text { setpoint }\end{array}$ & $\$ 0$ \\
\hline 490 & HVAC Equipment & $\begin{array}{l}\text { Replace HEPA filters with } \\
\text { low resistance filters }\end{array}$ & $\$ 850$ \\
\hline 490 & Motors & $\begin{array}{l}\text { Remove CW/Glycol } \\
\text { exchanger in ITF }\end{array}$ & $\$ 3,500$ \\
\hline 490 & Lighting & $\begin{array}{l}\text { Change lighting operating } \\
\text { schedule }\end{array}$ & $\$ 5,500$ \\
\hline 490 & Lighting & $\begin{array}{l}\text { Install more efficient } \\
\text { lighting system }\end{array}$ & $\$ 94$ \\
\hline 490 & HVAC Equipment & Replace HVAC equipment & $\$ 2,000$ \\
\hline 490 & Lighting & $\begin{array}{l}\text { Replace incandescent w/ } \\
\text { CFL }\end{array}$ & $\$ 703$ \\
\hline 490 & $\begin{array}{l}\text { Other } \\
\text { Recommendations }\end{array}$ & $\begin{array}{l}\text { Install high efficiency } \\
\text { evaporator fans }\end{array}$ & $\$ 289$ \\
\hline 490 & HVAC Equipment & $\begin{array}{l}\text { Install down draft ceiling } \\
\text { fan in seminar room }\end{array}$ & $\$ 500$ \\
\hline 490 & Motors & $\begin{array}{l}\text { Install high efficiency } \\
\text { motors }\end{array}$ & $\$ 1,836$ \\
\hline 490 & $\begin{array}{l}\text { Other } \\
\text { Recommendations }\end{array}$ & Shut down sub-zero boxes & $\$ 12,000$ \\
\hline 490 & Lighting & $\begin{array}{l}\text { Install T-8 lamps and } \\
\text { electronic ballasts }\end{array}$ & $\$ 80,056$ \\
\hline
\end{tabular}

\begin{tabular}{|c|c|c|c|c|c|c|}
\hline $\begin{array}{l}\text { Cost labor } \\
\text { (includes } \\
\text { disposal costs) }\end{array}$ & $\begin{array}{l}\text { Total } \\
\text { Cost }\end{array}$ & $\begin{array}{l}\text { Total Annual } \\
\text { Energy Savings: } \\
\text { (MMBtu/yr) }\end{array}$ & $\begin{array}{l}\text { Annual Cost } \\
\text { Savings: } \\
\text { Energy }\end{array}$ & $\begin{array}{c}\text { Annual Cost } \\
\text { Savings: O\&M }\end{array}$ & $\begin{array}{l}\text { Total Annual } \\
\text { Cost Savings }\end{array}$ & $\begin{array}{r}\text { Simple } \\
\text { Payback }\end{array}$ \\
\hline$\$ 147$ & $\$ 147$ & 37.26 & $\$ 1,309$ & $\$ 0$ & $\$ 1,309$ & 0.1 \\
\hline$\$ 5$ & $\$ 5$ & 0.20 & $\$ 4$ & $\$ 0$ & $\$ 4$ & 1.3 \\
\hline$\$ 945$ & $\$ 6,220$ & 96.17 & $\$ 2,192$ & $\$ 722$ & $\$ 2,914$ & 2.1 \\
\hline$\$ 272$ & $\$ 477$ & 5.23 & $\$ 119$ & $\$ 0$ & $\$ 119$ & 4.0 \\
\hline$\$ 810$ & $\$ 2,109$ & 18.98 & $\$ 433$ & $\$ 0$ & $\$ 433$ & 4.9 \\
\hline$\$ 375$ & $\$ 700$ & 0.03 & $\$ 142$ & $\$ 0$ & $\$ 142$ & 4.9 \\
\hline$\$ 911$ & $\$ 5,937$ & 48.72 & $\$ 1,111$ & $\$ 0$ & $\$ 1,111$ & 5.3 \\
\hline$\$ 107$ & $\$ 136$ & 0.82 & $\$ 19$ & $\$ 0$ & $\$ 19$ & 7.2 \\
\hline$\$ 2,081$ & $\$ 8,153$ & 33.51 & $\$ 764$ & $\$ 0$ & $\$ 764$ & 10.7 \\
\hline \multirow[t]{2}{*}{$\$ 5$} & $\$ 5$ & 5.18 & $\$ 26$ & $\$ 0$ & $\$ 26$ & 0.2 \\
\hline & $\$ 850$ & 93.03 & $\$ 2,120$ & $\$ 0$ & $\$ 2,120$ & 0.4 \\
\hline \multirow[t]{2}{*}{$\$ 0$} & $\$ 3,500$ & 226.97 & $\$ 5,174$ & $\$ 0$ & $\$ 5,174$ & 0.7 \\
\hline & $\$ 11,000$ & 655.94 & $\$ 14,952$ & $\$ 0$ & $\$ 14,952$ & 0.7 \\
\hline \multirow[t]{2}{*}{$\$ 59$} & $\$ 153$ & 0.49 & $\$ 11$ & $\$ 138$ & $\$ 149$ & 1.0 \\
\hline & $\$ 2,000$ & 101.61 & $\$ 1,837$ & $\$ 0$ & $\$ 1,837$ & 1.1 \\
\hline$\$ 275$ & $\$ 978$ & 17.66 & $\$ 402$ & $\$ 436$ & $\$ 838$ & 1.2 \\
\hline \multirow[t]{2}{*}{$\$ 130$} & $\$ 419$ & 6.99 & $\$ 159$ & $\$ 0$ & $\$ 159$ & 2.6 \\
\hline & $\$ 500$ & -1.35 & $\$ 167$ & $\$ 0$ & $\$ 167$ & 3.0 \\
\hline \multirow[t]{2}{*}{$\$ 456$} & $\$ 2,292$ & 27.04 & $\$ 616$ & $\$ 0$ & $\$ 616$ & 3.7 \\
\hline & $\$ 12,000$ & 105.93 & $\$ 2,439$ & $\$ 0$ & $\$ 2,439$ & 4.9 \\
\hline$\$ 30,024$ & $\$ 110,080$ & 873.42 & $\$ 19,910$ & $\$ 0$ & $\$ 19,910$ & 5.5 \\
\hline
\end{tabular}




\begin{tabular}{|c|c|c|c|c|c|c|c|c|c|c|}
\hline $\begin{array}{l}\text { Building } \\
\text { Number }\end{array}$ & $\begin{array}{l}\text { Measure } \\
\text { Category }\end{array}$ & Measure & $\begin{array}{c}\text { Cost: } \\
\text { materials }\end{array}$ & $\begin{array}{l}\text { Cost labor } \\
\text { (includes } \\
\text { disposal costs) }\end{array}$ & $\begin{array}{l}\text { Total } \\
\text { Cost }\end{array}$ & $\begin{array}{l}\text { Total Annual } \\
\text { Energy Savings: } \\
\text { (MMBtu/yr) }\end{array}$ & $\begin{array}{l}\text { Annual Cost } \\
\text { Savings: } \\
\text { Energy }\end{array}$ & $\begin{array}{l}\text { Annual Cost } \\
\text { Savings: O\&M }\end{array}$ & $\begin{array}{l}\text { Total Annual } \\
\text { Cost Savings }\end{array}$ & $\begin{array}{r}\text { Simple } \\
\text { Payback }\end{array}$ \\
\hline 510 & HVAC Equipment & $\begin{array}{l}\text { Reduce AHU operating } \\
\text { hours }\end{array}$ & $\$ 500$ & $\$ 0$ & $\$ 500$ & 662.86 & $\$ 16,466$ & $\$ 0$ & $\$ 16,466$ & 0.0 \\
\hline 510 & HVAC Equipment & $\begin{array}{l}\text { Install down draft ceiling } \\
\text { fan in High Bay Area }\end{array}$ & $\$ 450$ & $\$ 550$ & $\$ 1,000$ & -3.71 & $\$ 567$ & $\$ 0$ & $\$ 567$ & 1.8 \\
\hline 510 & Lighting & $\begin{array}{l}\text { Install more efficient exit } \\
\text { signs }\end{array}$ & $\$ 960$ & $\$ 270$ & $\$ 1,230$ & 5.74 & $\$ 131$ & $\$ 122$ & $\$ 253$ & 4.9 \\
\hline 510 & Motors & $\begin{array}{l}\text { Install high efficiency } \\
\text { motors }\end{array}$ & $\$ 4,600$ & $\$ 4,050$ & $\$ 8,650$ & 57.01 & $\$ 1,299$ & $\$ 0$ & $\$ 1,299$ & 6.7 \\
\hline 510 & Lighting & Install occupancy sensors & $\$ 18,750$ & $\$ 11,250$ & $\$ 30,000$ & 189.67 & $\$ 4,323$ & $\$ 0$ & $\$ 4,323$ & 6.9 \\
\hline 510 & HVAC Equipment & $\begin{array}{l}\text { Install down draft ceiling } \\
\text { fan in seminar room }\end{array}$ & $\$ 550$ & $\$ 650$ & $\$ 1,200$ & -4.46 & $\$ 144$ & $\$ 0$ & $\$ 144$ & 8.3 \\
\hline 510 & Lighting & $\begin{array}{l}\text { Install T-8 lamps and } \\
\text { electronic ballasts }\end{array}$ & $\$ 148,283$ & $\$ 49,939$ & $\$ 198,222$ & 722.77 & $\$ 16,476$ & $\$ 0$ & $\$ 16,476$ & 12.0 \\
\hline 515 & Motors & Install motor controls & $\$ 7,052$ & $\$ 1,440$ & $\$ 8,492$ & 114.13 & $\$ 2,601$ & $\$ 0$ & $\$ 2,601$ & 3.3 \\
\hline 515 & Lighting & Install occupancy sensors & $\$ 485$ & $\$ 495$ & $\$ 980$ & 8.88 & $\$ 202$ & $\$ 0$ & $\$ 202$ & 4.9 \\
\hline 515 & Lighting & $\begin{array}{l}\text { Install more efficient exit } \\
\text { signs }\end{array}$ & $\$ 960$ & $\$ 270$ & $\$ 1,230$ & 5.74 & $\$ 131$ & $\$ 122$ & $\$ 253$ & 4.9 \\
\hline 515 & Lighting & $\begin{array}{l}\text { Install T-8 lamps and } \\
\text { electronic ballasts }\end{array}$ & $\$ 50,617$ & $\$ 16,704$ & $\$ 67,321$ & 347.12 & $\$ 7,913$ & $\$ 0$ & $\$ 7,913$ & 8.5 \\
\hline 528 & Lighting & $\begin{array}{l}\text { Install T-8 lamps and } \\
\text { electronic ballasts }\end{array}$ & $\$ 3,575$ & $\$ 1,166$ & $\$ 4,741$ & 21.23 & $\$ 484$ & $\$ 0$ & $\$ 484$ & 9.8 \\
\hline 528 & HVAC Equipment & $\begin{array}{l}\text { Replace with high } \\
\text { efficiency HVAC } \\
\text { equipment }\end{array}$ & $\$ 34,000$ & & $\$ 34,000$ & 75.03 & $\$ 1,710$ & $\$ 0$ & $\$ 1,710$ & 19.9 \\
\hline 555 & $\begin{array}{l}\text { Other } \\
\text { Recommendations }\end{array}$ & Rebalance fume hoods & & & $\$ 223,000$ & $9,465.24$ & $\$ 82,000$ & & $\$ 82,000$ & 2.7 \\
\hline 555 & HVAC Control & $\begin{array}{l}\text { Individual lab two-speed } \\
\text { DDC fan control switch }\end{array}$ & & & $\$ 421,000$ & $8,785.87$ & $\$ 71,709$ & & $\$ 71,709$ & 5.9 \\
\hline 555 & Lighting & $\begin{array}{l}\text { Install T-8 lamps and } \\
\text { electronic ballasts }\end{array}$ & & & $\$ 212,000$ & 844.72 & $\$ 26,000$ & & $\$ 26,000$ & 8.2 \\
\hline
\end{tabular}




\begin{tabular}{|c|c|c|c|c|c|c|c|c|c|c|}
\hline $\begin{array}{l}\text { Building } \\
\text { Number }\end{array}$ & $\begin{array}{l}\text { Measure } \\
\text { Category }\end{array}$ & Measure & $\begin{array}{c}\text { Cost: } \\
\text { materials }\end{array}$ & $\begin{array}{l}\text { Cost labor } \\
\text { (includes } \\
\text { disposal costs) }\end{array}$ & $\begin{array}{l}\text { Total } \\
\text { Cost }\end{array}$ & $\begin{array}{l}\text { Total Annual } \\
\text { Energy Savings: } \\
\text { (MMBtu/vr) }\end{array}$ & $\begin{array}{l}\text { Annual Cost } \\
\text { Savings: } \\
\text { Energy }\end{array}$ & $\begin{array}{c}\text { Annual Cost } \\
\text { Savings: O\&M }\end{array}$ & $\begin{array}{l}\text { Total Annual } \\
\text { Cost Savings }\end{array}$ & $\begin{array}{r}\text { Simple } \\
\text { Payback }\end{array}$ \\
\hline 599 & HVAC Control & $\begin{array}{l}\text { Change HVAC setpoint } \\
\text { temps. }\end{array}$ & $\$ 0$ & $\$ 50$ & $\$ 50$ & 11.27 & $\$ 1,291$ & $\$ 0$ & $\$ 1,291$ & 0.0 \\
\hline 599 & Water Heating & $\begin{array}{l}\text { Reduce DHW temp. } \\
\text { setpoint }\end{array}$ & $\$ 0$ & $\$ 9$ & $\$ 9$ & 0.01 & $\$ 51$ & $\$ 0$ & $\$ 51$ & 0.2 \\
\hline 599 & Lighting & $\begin{array}{l}\text { Change lighting operating } \\
\text { schedule }\end{array}$ & $\$ 120$ & & $\$ 120$ & 19.06 & $\$ 434$ & $\$ 0$ & $\$ 434$ & 0.3 \\
\hline 599 & Lighting & Install outdoor photocell & $\$ 140$ & $\$ 90$ & $\$ 230$ & 18.57 & $\$ 423$ & $\$ 0$ & $\$ 423$ & 0.5 \\
\hline 599 & Lighting & $\begin{array}{l}\text { Replace incandescent w/ } \\
\text { CFL }\end{array}$ & $\$ 27$ & $\$ 11$ & $\$ 38$ & 0.38 & $\$ 9$ & $\$ 9$ & $\$ 18$ & 2.1 \\
\hline 599 & Lighting & $\begin{array}{l}\text { Install } \mathrm{T}-8 \text { lamps and } \\
\text { electronic ballasts }\end{array}$ & $\$ 5,734$ & $\$ 2,268$ & $\$ 8,002$ & 52.76 & $\$ 1,203$ & $\$ 0$ & $\$ 1,203$ & 6.7 \\
\hline 599 & Motors & $\begin{array}{l}\text { Install high efficiency } \\
\text { motors }\end{array}$ & $\$ 1,404$ & $\$ 0$ & $\$ 1,404$ & 8.10 & $\$ 185$ & $\$ 0$ & $\$ 185$ & 7.6 \\
\hline 703 & Lighting & $\begin{array}{l}\text { Replace incandescent w/ } \\
\text { CFL }\end{array}$ & $\$ 828$ & $\$ 302$ & $\$ 1,130$ & 20.03 & $\$ 457$ & $\$ 470$ & $\$ 927$ & 1.2 \\
\hline 703 & HVAC Equipment & $\begin{array}{l}\text { Test for and replace faulty } \\
\text { steam traps }\end{array}$ & $\$ 1,500$ & $\$ 1,272$ & $\$ 2,772$ & 0.37 & $\$ 1,804$ & $\$ 0$ & $\$ 1,804$ & 1.5 \\
\hline 703 & Lighting & Install IR sensors & $\$ 150$ & $\$ 90$ & $\$ 240$ & 3.79 & $\$ 86$ & $\$ 0$ & $\$ 86$ & 2.8 \\
\hline 703 & HVAC Equipment & $\begin{array}{l}\text { Install VFDs and reduce air } \\
\text { flow during unoccupied } \\
\text { hrs. }\end{array}$ & $\$ 114,500$ & & $\$ 114,500$ & $1,330.29$ & $\$ 26,572$ & $\$ 0$ & $\$ 26,572$ & 4.3 \\
\hline 703 & Motors & $\begin{array}{l}\text { Install high efficiency } \\
\text { motors }\end{array}$ & $\$ 8,818$ & $\$ 7,492$ & $\$ 16,310$ & 107.30 & $\$ 2,446$ & $\$ 0$ & $\$ 2,446$ & 6.7 \\
\hline 703 & Lighting & $\begin{array}{l}\text { Install T-8 lamps and } \\
\text { electronic ballasts }\end{array}$ & $\$ 12,974$ & $\$ 4,234$ & $\$ 17,208$ & 50.37 & $\$ 1,148$ & $\$ 0$ & $\$ 1,148$ & 15.0 \\
\hline 815 & HVAC Control & Reduce supply air flow & & & $\$ 18,000$ & $1,696.74$ & $\$ 12,463$ & & $\$ 12,463$ & 1.4 \\
\hline 815 & $\begin{array}{l}\text { Other } \\
\text { Recommendations }\end{array}$ & Reduce fume hood air flow & & & $\$ 10,000$ & 125.41 & $\$ 3,000$ & & $\$ 3,000$ & 3.3 \\
\hline 815 & Lighting & $\begin{array}{l}\text { Install } \mathrm{T}-8 \text { lamps and } \\
\text { electronic ballasts }\end{array}$ & & & $\$ 50,000$ & 168.94 & $\$ 6,000$ & & $\$ 6,000$ & 8.3 \\
\hline 815 & Chiller & $\begin{array}{l}\text { Replace existing chiller } \\
\text { with central plant chiller } \\
\text { water }\end{array}$ & & & $\$ 450,000$ & $4,516.78$ & $\$ 23,471$ & & $\$ 23,471$ & 19.2 \\
\hline 815 & Chiller & $\begin{array}{l}\text { Replace existing chiller } \\
\text { with double effect chiller }\end{array}$ & & & $\$ 336,000$ & $2,213.85$ & $\$ 16,607$ & & $\$ 16,607$ & 20.2 \\
\hline 815 & HVAC Equipment & Install VAV diffusers & & & $\$ 64,000$ & 232.41 & $\$ 2,730$ & & $\$ 2,730$ & 23.4 \\
\hline
\end{tabular}




\begin{tabular}{|c|c|c|c|c|c|c|c|c|c|c|}
\hline $\begin{array}{l}\text { Building } \\
\text { Number }\end{array}$ & $\begin{array}{l}\text { Measure } \\
\text { Category }\end{array}$ & Measure & $\begin{array}{c}\text { Cost: } \\
\text { materials }\end{array}$ & $\begin{array}{l}\text { Cost labor } \\
\text { (includes } \\
\text { disposal costs) }\end{array}$ & $\begin{array}{l}\text { Total } \\
\text { Cost }\end{array}$ & $\begin{array}{l}\text { Total Annual } \\
\text { Energy Savings: } \\
\text { (MMBtu/yr) }\end{array}$ & $\begin{array}{l}\text { Annual Cost } \\
\text { Savings: } \\
\text { Energy }\end{array}$ & $\begin{array}{c}\text { Annual Cost } \\
\text { Savings: O\&M }\end{array}$ & $\begin{array}{l}\text { Total Annual } \\
\text { Cost Savings }\end{array}$ & $\begin{array}{r}\text { Simple } \\
\text { Payback }\end{array}$ \\
\hline 835 & Lighting & $\begin{array}{l}\text { Replace incandescent w/ } \\
\text { CFL }\end{array}$ & $\$ 207$ & $\$ 43$ & $\$ 250$ & 4.77 & $\$ 109$ & $\$ 82$ & $\$ 191$ & 1.3 \\
\hline 835 & HVAC Control & $\begin{array}{l}\text { Install programmable } \\
\text { thermostats }\end{array}$ & $\$ 825$ & $\$ 495$ & $\$ 1,320$ & 1.89 & $\$ 1,006$ & $\$ 0$ & $\$ 1,006$ & 1.3 \\
\hline 835 & Lighting & $\begin{array}{l}\text { Install more efficient } \\
\text { lighting systems }\end{array}$ & $\$ 136$ & $\$ 90$ & $\$ 226$ & 3.26 & $\$ 74$ & $\$ 9$ & $\$ 83$ & 2.7 \\
\hline 835 & Lighting & $\begin{array}{l}\text { Install T-8 lamps and } \\
\text { electronic ballasts }\end{array}$ & $\$ 1,296$ & $\$ 540$ & $\$ 1,836$ & 16.70 & $\$ 381$ & $\$ 0$ & $\$ 381$ & 4.8 \\
\hline 835 & Lighting & $\begin{array}{l}\text { Energy efficient lamps and } \\
\text { electronic ballasts }\end{array}$ & $\$ 1,435$ & $\$ 547$ & $\$ 1,982$ & 12.05 & $\$ 275$ & $\$ 0$ & $\$ 275$ & 7.2 \\
\hline 901 & HVAC Control & Reduce supply air & & & $\$ 6,000$ & 85.76 & $\$ 2,000$ & & $\$ 2,000$ & 3.0 \\
\hline 901 & Lighting & $\begin{array}{l}\text { Install T- } 8 \text { lamps and } \\
\text { electronic ballasts }\end{array}$ & & & $\$ 106,000$ & 371.68 & $\$ 11,000$ & & $\$ 11,000$ & 9.6 \\
\hline 901 & Chiller & Replace chiller & & & $\$ 206,000$ & 252.01 & $\$ 10,000$ & & $\$ 10,000$ & 20.6 \\
\hline 901 & HVAC Equipment & Install VAV diffusers & & & $\$ 26,000$ & 54.99 & $\$ 1,006$ & & $\$ 1,006$ & 25.8 \\
\hline $1005 \mathrm{~S}$ & HVAC Equipment & $\begin{array}{l}\text { Install high efficiency } \\
\text { filters }\end{array}$ & $\$ 0$ & $\$ 0$ & $\$ 0$ & 36.35 & $\$ 829$ & $\$ 331$ & $\$ 1,160$ & 0.0 \\
\hline $1005 \mathrm{~S}$ & HVAC Control & $\begin{array}{l}\text { Change HVAC setpoint } \\
\text { temp. }\end{array}$ & $\$ 500$ & & $\$ 500$ & 4.42 & $\$ 1,342$ & $\$ 0$ & $\$ 1,342$ & 0.4 \\
\hline $1005 \mathrm{~S}$ & Lighting & $\begin{array}{l}\text { Install more efficient exit } \\
\text { signs }\end{array}$ & $\$ 275$ & $\$ 248$ & $\$ 523$ & 9.54 & $\$ 217$ & $\$ 135$ & $\$ 352$ & 1.5 \\
\hline $1005 \mathrm{~S}$ & Lighting & $\begin{array}{l}\text { Replace incandescent w/ } \\
\text { CFL }\end{array}$ & $\$ 202$ & $\$ 32$ & $\$ 234$ & 4.89 & $\$ 111$ & $\$ 44$ & $\$ 155$ & 1.5 \\
\hline $1005 \mathrm{~S}$ & Lighting & Install occupancy sensors & $\$ 225$ & $\$ 135$ & $\$ 360$ & 5.17 & $\$ 118$ & $\$ 0$ & $\$ 118$ & 3.1 \\
\hline $1005 \mathrm{~S}$ & Lighting & $\begin{array}{l}\text { Install T-8 lamps and } \\
\text { electronic ballasts and } \\
\text { reflectors }\end{array}$ & $\$ 657$ & $\$ 194$ & $\$ 851$ & 7.86 & $\$ 179$ & $\$ 0$ & $\$ 179$ & 4.8 \\
\hline $1005 \mathrm{~S}$ & Lighting & $\begin{array}{l}\text { Install T-8 lamps and } \\
\text { electronic ballasts }\end{array}$ & $\$ 12,837$ & $\$ 5,011$ & $\$ 17,848$ & 144.53 & $\$ 3,294$ & $\$ 0$ & $\$ 3,294$ & 5.4 \\
\hline $1005 \mathrm{~S}$ & HVAC Equipment & $\begin{array}{l}\text { Install down draft ceiling } \\
\text { fans in high bay areas }\end{array}$ & $\$ 600$ & $\$ 600$ & $\$ 1,200$ & -4.48 & $\$ 175$ & $\$ 0$ & $\$ 175$ & 6.9 \\
\hline $526 \& 527$ & Lighting & $\begin{array}{l}\text { Install wall switch to } \\
\text { control lighting }\end{array}$ & $\$ 40$ & $\$ 135$ & $\$ 175$ & 2.08 & $\$ 47$ & $\$ 0$ & $\$ 47$ & 3.7 \\
\hline $526 \& 527$ & HVAC Equipment & $\begin{array}{l}\text { Install down draft ceiling } \\
\text { fans in high bay areas }\end{array}$ & $\$ 1,000$ & $\$ 600$ & $\$ 1,600$ & -5.52 & $\$ 407$ & $\$ 0$ & $\$ 407$ & 3.9 \\
\hline $526 \& 527$ & Lighting & Install occupancy sensors & $\$ 225$ & $\$ 135$ & $\$ 360$ & 1.91 & $\$ 44$ & $\$ 0$ & $\$ 44$ & 8.2 \\
\hline \multicolumn{5}{|c|}{ Summary Data } & $\$ 3,745,556$ & & & & & \\
\hline
\end{tabular}


APPENDIX G

EXAMPLE CALCULATIONS FROM MOTOR MASTER 


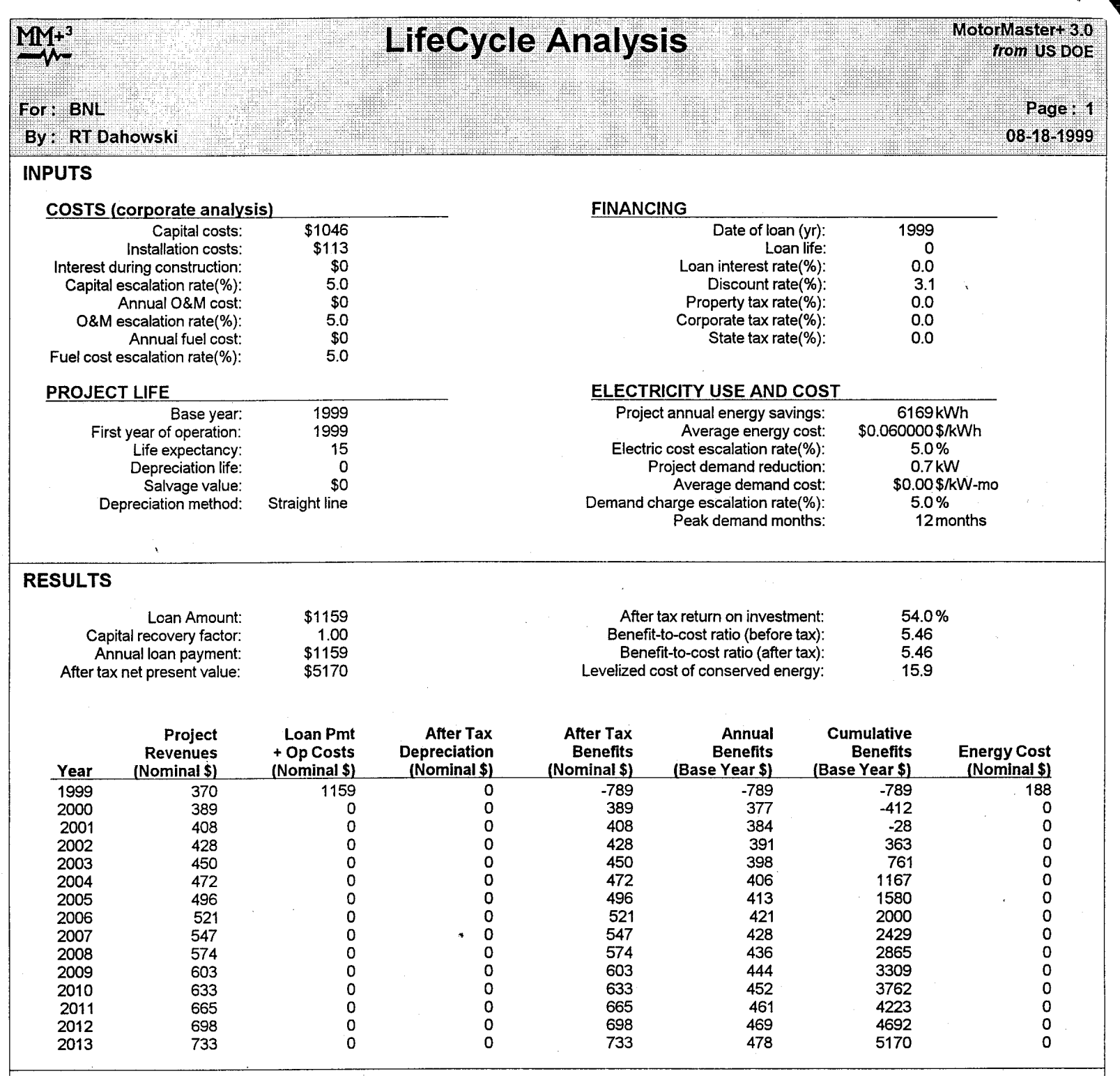




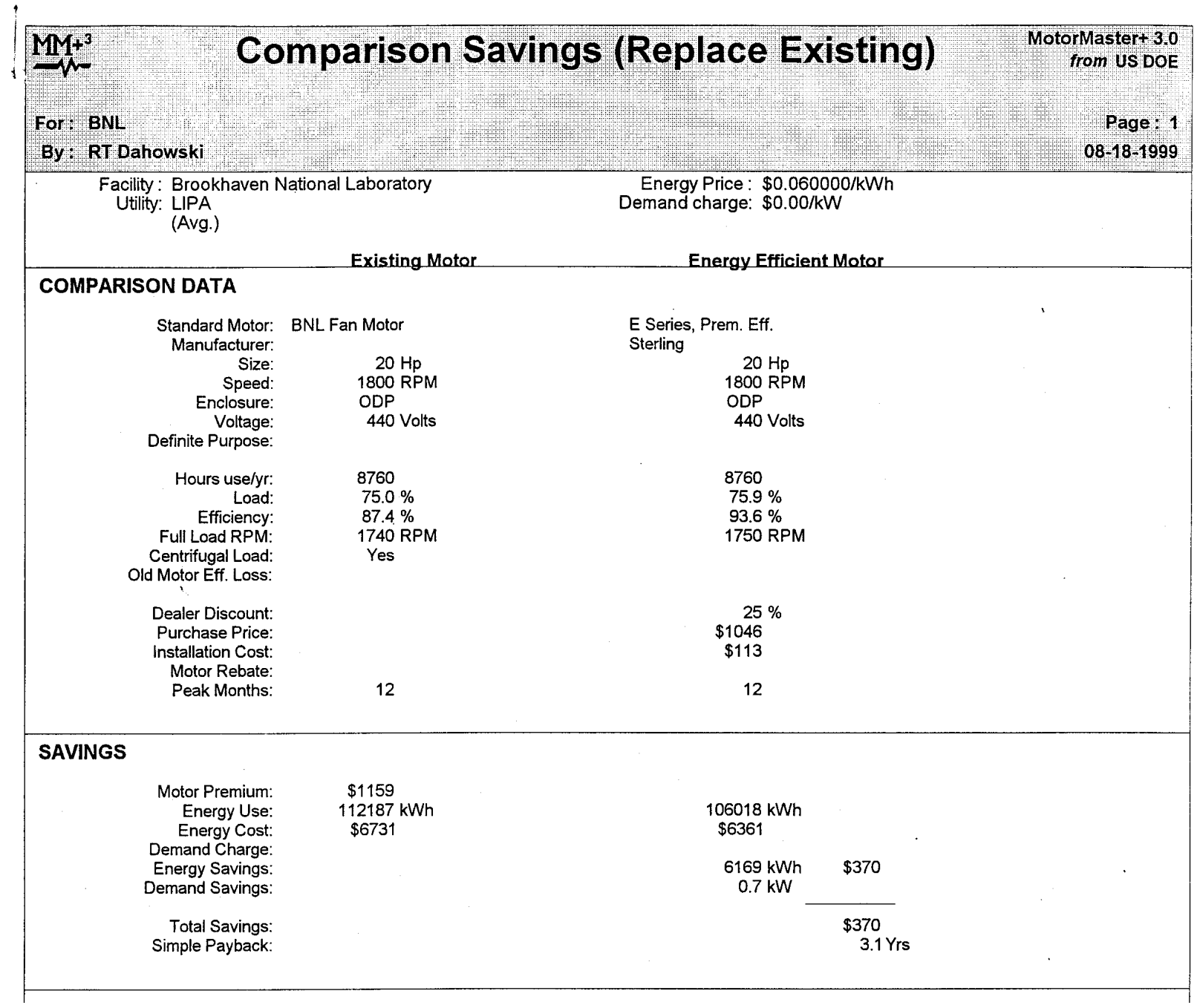




\section{APPENDIX H}

\section{CONTRACTED SERVICES PER E. BYRN}


Contracted Services: Assume a construction or service contract for $\$ 1,000,000$

Ed Byrn's Options, 8/11/99
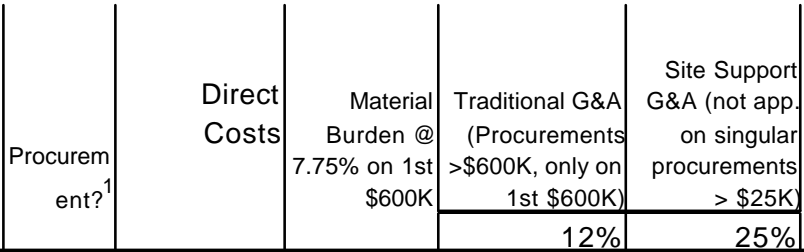

Total

Option 1: traditional construction contract

\begin{tabular}{l|r|r|r|r|r|r}
\hline $\begin{array}{l}\text { A lum sum contract of } \$ 1,000,000 \\
\text { Material Burden on Procurement }\end{array}$ & $p$ & $1,000,000$ & & 72,000 & - & $1,072,000$ \\
\hline Engineering (In-house), \% of contact cost 14\% & & 140,000 & & 5,580 & 11,625 & 63,705 \\
\cline { 3 - 6 } & & $1,140,000$ & 46,500 & 94,380 & 45,000 & 191,800 \\
\hline
\end{tabular}

Total burdens/overhead

187,505

Option 2: BNL buys materials, contractor installs

\begin{tabular}{|c|c|c|c|c|c|c|c|}
\hline $\begin{array}{l}\text { A contract for installation } \\
\text { Material Burden on Procurement }\end{array}$ & & $\mathrm{p}$ & 600,000 & 46.500 & $\begin{array}{r}72,000 \\
5,580 \\
\end{array}$ & $\begin{array}{c}- \\
11,625 \\
\end{array}$ & $\begin{array}{r}672,000 \\
63,705 \\
\end{array}$ \\
\hline $\begin{array}{l}\mathrm{PO} \text { to purchase materials } \\
\text { Material Burden on Procurement }\end{array}$ & & $\mathrm{p}$ & 200,000 & 15,500 & $\begin{array}{r}24,000 \\
1,860 \\
\end{array}$ & $\begin{array}{c}- \\
3.875 \\
\end{array}$ & $\begin{array}{r}224,000 \\
21,235 \\
\end{array}$ \\
\hline $\begin{array}{l}\text { POs to purchase materials }<\$ 25 \mathrm{~K} \\
\text { Material Burden on Procurement }\end{array}$ & & & 200,000 & 15,500 & $\begin{array}{r}24,000 \\
1,860 \\
\end{array}$ & $\begin{array}{r}50,000 \\
3,875 \\
\end{array}$ & $\begin{array}{r}274,000 \\
21,235 \\
\end{array}$ \\
\hline \multirow[t]{2}{*}{ Engineering (In-house), $\%$ of contact cost } & \multirow[t]{2}{*}{$14 \%$} & & 140.000 & & 16.800 & 35.000 & 191.800 \\
\hline & & & $1,140,000$ & 77,500 & 146,100 & 104,375 & $1,467,975$ \\
\hline
\end{tabular}

Total burdens/overhead

327,975

Option 3: BNL buvs and installs materials

\section{Labor}

PO to purchase materials

Material Burden on Procurement

POs to purchase materials $<\$ 25 \mathrm{~K}$

Material Burden on Procurement

Engineering (In-house), \% of contact cost

\begin{tabular}{|c|c|c|c|c|c|c|}
\hline t & $p$ & $\begin{array}{l}600,000 \\
200,000\end{array}$ & 15.500 & $\begin{array}{c}72,000 \\
24,000 \\
1,860 \\
\end{array}$ & $\begin{array}{c}150,000 \\
- \\
3.875 \\
\end{array}$ & $\begin{array}{r}822,000 \\
224,000 \\
21,235 \\
\end{array}$ \\
\hline t & & 200,000 & 15,500 & $\begin{array}{r}24,000 \\
1,860 \\
\end{array}$ & $\begin{array}{r}50,000 \\
3,875 \\
\end{array}$ & $\begin{array}{r}274,000 \\
21,235 \\
\end{array}$ \\
\hline \multirow{2}{*}{ tact cost } & & 140.000 & & 16.800 & 35.000 & 191.800 \\
\hline & & $1,140,000$ & 31,000 & 140,520 & 242,750 & $\begin{array}{r}\mathbf{1 , 5 5 4 , 2 7 0} \\
414,270\end{array}$ \\
\hline
\end{tabular}

Total burdens/overhead

Option 4: Strawman: ESPCasa Desian/Build proiect

A lum sum contract of $\$ 1,000,000$

$\mathrm{A} / \mathrm{E}$ design service moved to ESCO

A lum sum contract of $\$ 1,000,000$

Material Burden on Procurement

Engineering (In-house), \% of contact cost

Total burdens/overhead

\begin{tabular}{r|r|r|r|r|r|r}
$8 \%$ & & $\begin{array}{r}1,000,000 \\
80,000\end{array}$ & & & & \\
\cline { 4 - 6 } & \multirow{2}{*}{$\mathrm{p}$} & $1,080,000$ & & & & \\
& & & & 72,000 & - & $1,152,000$ \\
& & 46,500 & 5,580 & 11,625 & 63,705 \\
\hline & & 64,800 & & 7,776 & 16,200 & 88,776 \\
\hline & $1,144,800$ & 46,500 & 85,356 & 27,825 & $\mathbf{1 , 3 0 4 , 4 8 1}$ \\
& & & & & & 159,681
\end{tabular}

Note 1: If Procurement is single item > $\$ 25 \mathrm{~K}$, enter "p" 
APPENDIX I

"FINANCING ENERGY PROJECTS AT FEDERAL FACILTIES: A SCREENING TOOL FOR DECISION MAKING”' (Carroll 1999 - PNNL-SA-30924) 


\section{Background}

Federal sites are faced with many challenges in managing their energy efficiency and utilities management programs, one of the greatest being limited funding. Upgrades to energy and utility systems may be required to:

- Reduce energy consumption to meet energy-efficiency goals.

- Reduce energy costs to meet resource restrictions such as budget cuts.

- Meet regulatory requirements such as the chlorofluorocarbon (CFC) phaseout.

- Support new mission demands such as an electrical capacity upgrade required for a new flight simulator.

- Improve the quality of life for the building tenants.

- $\quad$ Reduce the repair costs required to keep a utility system operational beyond its normal functional life.

There are many financing options/alternatives available to Federal sites for energy-efficiency projects including Energy Service Performance Contracts, various Utility Energy Service Contracts, utility rebates, and, to an increasingly limited degree, internally funded project execution programs. As internal funds become even more constrained, it is critical for the installation-level energy manager to consider alternative financing sources for energy-efficiency projects.

The types of energy systems included in typical energyefficiency programs include the following:

- Building envelope

- Building automation systems/energy management and control systems

- Boilers

- Chillers

- Heating, ventilating, and air conditioning (HVAC), including pumps, fans, and rooftop units

- Variable air volume retrofit

- Refrigeration

- $\quad$ Lighting

- Thermal distribution systems (chilled water, hot water, and steam)

- $\quad$ Steam traps

- Piping insulation

- Electric motors and drives

- Electric distribution systems

- Cogeneration systems

- Renewable energy systems.

\section{Purpose}

It is important to understand the various project financing options currently available and how to evaluate them, at least to a degree that will allow the wise selection of the most appropriate option that meets general and site specific criteria. This paper describes a seven-step process to determine which options are most advantageous to your site. The discussion that follows leads to an options matrix designed to assist in documenting your decision process for selection of a financing option. Additional background information regarding aspects of the selection process can be obtained from various World Wide Web sites identified later in this document.

In applying alternative financing, Federal energy managers and their contracting officers find themselves on the cutting edge of Federal acquisition reform. The use of alternative financing offers Federal agencies the opportunity to apply "best value" business practices to achieve significant energy and cost savings, replace aging and inefficient energy using equipment, and rehabilitate and renovate facilities using appropriate private sector resources.

The use of any of the innovative, privately financed energy efficiency contracting methods requires that the Federal agency evaluate all available options and select the option that provides the best value to the government for the specific application under consideration. Recognizing that the needs, opportunities and constraints at each Federal site are unique, the selection must take into consideration all of the specific issues of significance at the individual site.

Important Note: During the course of completing the selection process, a project acquisition team will need to be assembled from all of the organizational groups that will be affected by the project, including engineering, contracting, legal, operations and maintenance, environmental, the comptroller, and site upper management. The team will be responsible for identifying the facility specific constraints, which may include mission support concerns, environmental issues, personnel constraints, core capabilities, infrastructure needs, and contract length. The acquisition team should develop a consensus on the relative priority of issues to be addressed in the option analysis. All relevant issues must be considered by the acquisition team in making the "best value" determination for the particular and unique facility.

\section{Step 1. Define the objectives}

The first step is to clearly understand your specific objectives. You must identify your goals so that you can ensure that the option(s) you select meets those goals and supports your mission.

Examples of goals and objectives that your energy project may focus on include:

- $\quad$ Save energy

- $\quad$ Reduce costs 
- Respond to changing mission requirements

- Meet other mandates such as the CFC phaseout

- Infrastructure improvements

Do not overlook the potential to achieve energy savings coincident with other projects. Replacement of a chiller to phase out CFCs also presents an opportunity to analyze the chiller plant for energy-efficiency opportunities through proper sizing of the equipment, and installation of a highefficiency chiller. Lighting retrofit projects originally designed to save energy can also significantly improve the quality of the lighting in a building, and thereby the work environment for the building occupants.

A project can consist of a single energy conservation measure (ECMs), or a group of ECMs. Typically, it is best to group measures into a project that provides the best overall value. In addition, there are natural combinations that should always be considered such as lighting and heating and cooling measures.

A complete understanding of the project objectives will allow you to determine if the decision to proceed with the project (the "go/no go" decision) is based on the economics of the project, or if it is a mandatory project. In either case, you will need to determine how to finance the project.

Ensure that you have an accurate baseline of energy consumption and costs before beginning the project cycle. This provides both invaluable technical information for identifying energy projects that are cost-effective and financial information to demonstrate the true impact of your energy-efficiency program.

It is important to ensure that both the local on-site and the agency management staff understand the importance of the project. This is a good time to brief them about the project and get their support. More detailed information regarding this activity is provided in Step 5.

If you anticipate using either the Department of Energy (DOE) regional or technology Super Energy Savings Performance Contracts (ESPC), then a Memorandum of Understanding (MOU) must be established between your agency and DOE. In addition, a Memorandum of Agreement (MOA) may be required between various offices within your agency before a contract for the energy project can be awarded. These requirements should be identified and steps taken to put them in place early to avoid delays in the project execution cycle.

\section{Step 2. Define criteria that influence the selection of funding source}

Some criteria may outweigh the economic or energy impacts of a project. Examples include code compliance (such as building ventilation requirements), inspection by outside agencies (including environmental and safety), and programmatic desires of your agency. You can ensure the project meets these criteria by considering the following:

- Programmatic focus

- Mission requirements

- Safety/health

- Projected life of the buildings in question (consult your site master plan)

- Support to provide the resources to implement the project

- Existing agreements with on-site tenants

- Current level of on-site support capabilities

- Retention of existing service capabilities

- Contractual arrangement with service providers

- Innovative technology requirements.

Existing site operations and maintenance (O\&M) subcontracts that might be impacted by the energy projects must also be identified and considered. Some energy projects might require elimination of service contract work elements or modification of those elements. The energy project involving existing O\&M staff should include training for your maintenance staff or facilities services contractors, or coordination with construction contracts ongoing at your site.

Environmental requirements and impacts must be considered in planning any project. A relighting project that replaces existing fluorescent lamps may require that the old lamps be disposed of as hazardous waste because they contain mercury. Other environmental concerns routinely encountered include disposal of transformers and ballasts containing polychlorinated biphenyls (PCBs), CFC refrigerants, asbestos insulation, and lead-based paints.

\section{Step 3. Estimating the potential for energy savings}

The next step is to determine what your potential for energy savings is, and therefore which financing options are most attractive. Let's assume that the potential cost reduction is $15 \%$, purely for purpose of demonstrating the impact of project size on financing options. The net savings available to a small site with an annual utility bill of $\$ 50,000$ would be $\$ 7,500$ per year, while the savings available to a site with an annual utility bill of $\$ 4,000,000$ would be $\$ 600,000$ per year. These two sites will attract very different financing alternatives.

In addition to knowing your total energy bill for comparison of options, you should also calculate your unit energy cost (dollars per square foot) by dividing your total 
energy bill by your gross square footage. The cost of executing site-wide energy-efficiency projects will be related to the facility size. Sites, even large ones, that have low-cost energy may not be able to generate the savings required to amortize the capital investment required by the energy projects. Similarly, small sites with high cost energy may not be able to generate enough savings to cover the overhead costs associated with establishing an on-site energy management contract, and will be better serviced by demand-side management programs through their local utility company.

As demonstrated below, if your site is paying $\$ 1.50$ per square foot per year in energy costs, has 222,222 square feet of building space in the project and is able to reduce total building energy use by $15 \%$, the project will generate $\$ 50,000$ per year in savings. This will allow you to estimate whether the cost savings will pay for the needed upgrades to get a $15 \%$ energy savings.

Potential dollar savings $=$ Square footage $\times$ $\frac{\text { Annual energy cost }}{\text { Square foot }} \times$
Potential percent reduction in energy costs

Potential savings $=222,222 \mathrm{SF} \times \frac{\$ 1.50}{\mathrm{SF}} \times 15 \%$ $=\$ 50,000$

An investment of $\$ 250,000$ with potential savings of $\$ 50,000$ per year will generate a 5-year simple payback. Because the contract term for an alternatively financed project typically equals about twice the simple payback, a 5 -year simple payback results in a 10-year contract term

$$
\begin{aligned}
& \text { Contract term }=2 \times \frac{\text { Capital investment }}{\text { Annual savings }} \\
& \quad=2 \times \frac{\$ 250,000}{\$ 50,000 \text { per year }} \\
& =10 \text { years }
\end{aligned}
$$

It should be noted that other savings streams may occur as result of a proposed project. These include avoided onetime equipment repair cost, equipment upgrade cost, programmatic savings from avoided downtime, and reduction in O\&M cost. The applicability of these savings will depend on a variety of factors that must be considered on a site-by-site basis.

Now that we have a feel for the potential scope of the project, we can identify funding sources.

Version 5.7

Dated: 04/19/00

\section{Step 4. Define potential funding scenarios}

Funding sources include:

- Agency funding using appropriated funds from (depending on the amount being sought):

* The Command's/site's budget for O\&M projects and minor construction

* Appropriated funding from the chain of command

* Energy Conservation Investment Program (ECIP) funding for military construction (MILCON) level projects (Department of Defense)

* Other agency line-item funding authorization/appropriation.

- Utility Energy Service Contracts (UESC) may include a wide range of services from auditing to installation and commissioning, including financing the entire project. These were referred to as Utility Incentive Programs in the Energy Policy Act. These could be structured as:

* Customized site energy service agreements

* Customized agency energy service agreements

* Service programs under a General Services Agency (GSA) area-wide contract

* Basic Ordering Agreements

* Demand-side management programs or rebates.

- Energy Savings Performance Contracting (ESPC), including:

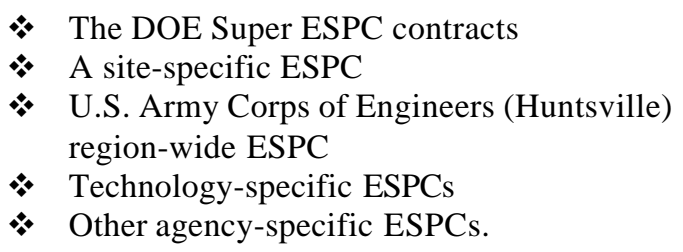

A crucial question that must be answered early in the process is which funding mechanisms are available? The lack of a funding mechanism may be a "show stopper" for that option, although the fact that it is not available today does not mean that it cannot be made available. It will, however, require longer project development lead time and higher development costs.

The range of projects packaged together will be affected by the funding mechanism selected. The site must carefully compare the funding or project options and determine their criteria for selecting the range of projects to be packaged those individual projects with the shortest payback, or the collection of projects with the lowest life-cycle cost. 


\section{Appropriated Funds}

Direct appropriations allow the agency to retain all of the savings from energy projects. In addition, given the uncertainty of deregulation and its impact on the cost of energy, appropriated funds provide greater flexibility to deal with those short term changes.

With the current emphasis on reducing the Federal Government's appropriations, however, energy and facility-related projects not directly related to the agency's mission may not be fully funded or may be delayed.

The disadvantages of appropriated funding are that the Government must provide the up-front capital funding to execute the project, and assume the risk of ensuring proper execution, operation, and maintenance. The source of the capital funding will depend on the scope of the project, and may range from the site's budget for minor construction, to a special project funded by the agency, to the Energy Conservation Investment Program (ECIP) for the Department of Defense, or other line-item funding programs. The funding cycle for appropriated funds is typically 1 to 5 years or longer from project submission to project funding.

Alternative financing methods were made available for the purpose of displacing appropriations to finance energy efficiency.

\section{Strengths:}

- Project development costs tend to be lower using agency funding for small to medium projects.

- The agency retains all savings.

- Appropriated funds are most appropriate for "common" technologies (i.e., lighting and motors), where there is a high probability of successful energy savings.

- The agency has control over design and construction award, giving the agency greater responsiveness for urgent projects.

- The agency has no contractual obligation beyond the construction contract and has complete operational flexibility.

- This option is appropriate for low-cost projects where the agency does not delay the project while seeking Congressional approval.

\section{Weaknesses:}

- Up-front capital costs are higher because the agency provides all funding (note that over the life of the project, the agency avoids financing costs by providing up-front funding).

- There is a very low priority in all agencies for energy conservation projects in the current budget environment.

- For lengthy funding and project execution cycles, the agency loses the potential energy savings during this period.

- The agency is responsible for all aspects of successful project execution to ensure energy and cost savings. For technically challenging projects (i.e., controls or cogeneration), the agency may have difficulty in ensuring adequate project execution.

- Commissioning is not required and often not performed and equipment performance is rarely verified.

\section{Utility Energy Service Contracts}

The Energy Policy Act of 1992 (EPAct) authorizes and encourages Federal agencies to participate in utility programs. These programs range from rebates on a piece of equipment all the way to delivering a complete turnkey project. Services provided for a project can range anywhere from auditing to installation and commissioning, including financing the entire project.

Utility rebate programs allow the Government to retain $100 \%$ of the rebate through credits to the routine billing. This can be used in conjunction with financed projects to reduce the up-front capital investment required. However, few utility rebate programs actually exist today. Instead, the direction is to provide energy management services to their customers that include audits, feasibility studies, engineering design, construction, and operations and maintenance services.

Utility Energy Service Contracts that are offered by the site's servicing utility typically involve any activity that reduces the peak demand for, or usage of, electricity, natural gas, and/or water. Utility companies that offer these programs typically provide financial assistance. In the current era of electric utility deregulation, these utility programs are being offered to meet customer needs. Programs actions usually fall into the following categories:

- Those that change the timing of energy usage so that utility supply-side (production and distribution) facilities have adequate capacity to meet peak demand at reasonable cost. These actions also result in reduced cost to customers through favorable tariff rates or energy storage technologies. 
- Those that improve the efficiency with which customers use the energy/service so that usage is permanently reduced.

Utility Energy Service Contracts that are available typically include incentives such as:

- Free or low-cost energy audits

- Rebates to reduce the capital cost of energy efficient technologies

- Special tariff rates for reducing demand upon request by the utility

- Full financing of efficiency projects; or prequalification of energy service contractors who would enter into contracts for turnkey project implementation.

Utility Energy Service Contracts can be negotiated to include operations and maintenance, guaranteed energy savings, and performance measurement and verification.

Project financing typically includes contracting with the energy service contractor for project execution. This allows the Government agency to execute projects without making the up-front capital investment, and to repay the financing through their utility service payments. The availability of this option is very site specific and dependent on service programs offered by your utility.

\section{Strengths:}

- Zero up-front capital costs if the utility finances the entire project. Project development costs are low, but may include modification of the site's utility contract or existing GSA Area-Wide with the Utility.

- If rebates are available, the agency retains all savings. If the utility provides financing, then the agency will have to repay the cost of the project to the utility. These must be factored into the economics of the project.

- The agency, working with the utility, has control over design and construction award, giving the agency greater responsiveness for urgent projects.

- Financing and rebates, if available, are generally not dependent on the size of the project.

\section{Weaknesses:}

- The agency is normally responsible for all aspects of successful project execution to ensure energy and cost savings. These elements may be written into a performance contract with the utility, but at an added cost to the agency.

- For technically challenging projects (i.e., controls or cogeneration), the agency may want to pay the utility to be responsible for ensuring adequate design, construction, commissioning, operations and maintenance.

- If an agency incurs a financial obligation as part of the Utility Energy Service Contract, it may create obligations that impact flexibility, such as changing mission or increase the work force.

- Deregulation may impact the availability of utility programs over time.

- The utility may only be able to fund a portion of the project due to restrictions regarding length of payback (10 years).

\section{Energy Savings Performance Contracts}

In April 1986, Congress passed Public Law 99-272, which gave Federal agencies the authority to enter into long-term (up to 25-year) contracts for shared energy savings services. This law, codified as 10 USC 2865 for DoD and 42 USC 8287 for civilian agencies, allows the Government to acquire energy-efficiency projects financed by private capital, where the contractor return-on-investment is recouped through a share of the savings directly resulting from the contractor's energy savings measures.

The National Energy Policy Act of 1992 renamed this class of procurement Energy Savings Performance Contracting, but the basic concepts remained the same. The contractor must guarantee a minimum performance level, to be verified by annual energy savings audit, and may be required to operate and maintain all equipment installed under the contract. The contractor is also responsible for all aspects of project performance, and does not get paid unless energy savings guaranteed by the contractor, typically referred to as an energy services company (ESCO), are realized. The savings must be guaranteed by the ESCO in the delivery order that they are awarded.

The risk for guaranteed energy savings that the ESCO assumes is negotiable, and may vary from ESCO assumption of all of the risk to the Government sharing the risk. The Government may choose to assume the risk to change the project cash/payment flow (i.e., to reduce the delivery order term). ESPC contracts are attractive when the Government cannot fund a project, and where the contractor can offer special expertise and innovative technologies that might not otherwise be available. 
To make it easier for agencies to use ESPC, the Department of Energy's (DOE) Federal Energy Management Program (FEMP) has developed Super ESPCs based on the Indefinite Delivery Indefinite Quantity provision of the Federal Acquisition Regulations (FAR). Super ESPCs are broad regional area contracts that allow Federal sites to negotiate site-specific ESPCs (i.e., place a delivery order) with an ESCO who has been competitively selected and approved by DOE without having to start the contracting process from scratch. In this way, agencies can effectively "piggy back" their ESPC projects onto a broader "Super ESPC", saving time as well as energy and money.

Elements included in an ESPC delivery order request for proposals (RFP) include site-specific terms and conditions, a technical description of the projects desired, and may include a site data package. The site data package (SDP), if required, contains data on the buildings included in the delivery order, historical energy consumption and cost data, building operational data, and a description of the energy-using equipment (i.e., lighting or air conditioning). Both the RFP and SDP are developed by the site/agency. The DOE FEMP Internet home page, listed later in this paper, contains delivery order guidelines and sample delivery order RFPs and SDPs.

The cost for establishing a DOE Super ESPC delivery order varies depending on the amount of support required. The basic user-fee for a delivery order is $\$ 10,000$, if the agency provides all technical and contracting support. If the agency requires assistance with engineering, contracting, and legal support, the fee is $\$ 50,000$ for Government-identified projects, and $\$ 30,000$ for ESCOidentified projects. These services are available through the FEMP Service Network.

The annual fee for engineering, contracting, and legal support for a delivery order under the U.S. Army Corps of Engineers (COE) (Huntsville) region-wide ESPC is $1 \%$ of the total energy bill (electricity and natural gas). This fee is negotiable, but $1 \%$ is a good starting point for estimating support costs.

A rule-of-thumb to determine the economic viability of an ESPC project is that the annual dollar savings potential should be greater than $\$ 25,000$. The Super ESPC contract specifies a minimum delivery order value of $\$ 150,000$, but it is not realistic to specify delivery orders that result in payments to the ESCO of less than $\$ 25,000$ per year. This is the basis for the advice on minimum delivery orders given above.

Many ESCOs look for sites with annual energy cost of at least $\$ 500,000$, which at $\$ 1.50$ per square foot per year would require a facility of around 333,333 square feet.

\section{Strengths:}

- Zero up-front capital costs because the ESCO finances the project. Contract term can be up to 25 years. Available utility rebates can be utilized to reduce overall capital costs.

- The ESCO is typically responsible for proper operations and maintenance to ensure continued energy savings over the life of the installed equipment.

- The ESCO is responsible for guaranteed energy savings to be verified annually. Measurement and verification must be included, however, in the project cost.

- The ESCO must provide a minimum level of service reliability as agreed to in the delivery order.

- The ESCO is responsible for energy savings and has specialized expertise to ensure successful project execution and operation.

- The agency performs a design review of the ESCO's proposal as opposed to the project design.

\section{Weaknesses:}

- Project development costs include a user-fee to DOE/DoD. Maximum savings does not occur until the ESCO recoups the capital investment.

- Changes in operations that impact the ESCO's ability to retain energy savings (in repayment for the capital investment) may create a contractual obligation that will require contract renegotiations.

- Utility rates are typically specified in the delivery order and are constant during the period of performance. If deregulation is expected in the short term, the agency should determine the expected impact on utility prices.

- Although energy financiers will work at smaller sites, we can't ignore the fact that facility size does matter to the project's potential payback, and therefore to their interest in establishing projects. Smaller sites, unless they have unusually high energy usage intensities or high energy rates, may be better serviced by a Utility Energy Service Contract or a small and disadvantaged 8(a) ESCO if they cannot provide in-house project financing.

- $\quad$ ESPCs require long-term management throughout the contract term because energy savings must be verified annually. 


\section{Step 5. Identify the site resources required to execute the various options}

No matter which option is selected, the site will be required to dedicate resources (both funding and manpower) to execute the project. The resources required for project execution will vary depending on the funding scenario selected. For example, although an ESPC delivery order will not require the development of plans and specifications that would be required for an agencyfunded project, it may require the development of an RFP and SDP.

Specific resources required prior to project execution include:

- Project identification and analysis

- Engineering design or design contract management

- Construction management and inspection

- Commissioning or performance verification to ensure that the design performance is realized

- Measurement and verification of actual savings to be performed annually.

Contracting skills are needed to:

- Select the appropriate contracting mechanism

- Make award

- Perform contract management.

If on-site support resources are not available, they can be procured through the FEMP Service Network - See Step 4.

Important Note: The FEMP Measurement and Verification $(M \& V)$ Guideline provides procedures and guidelines for quantifying the savings resulting from the installation of energy conservation measures (ECMs). Normally required for use in ESPC contracting and utility program projects, the guideline provides the methodology for establishing energy cost savings.

The objective of measurement and verification is to verify savings with minimum cost and to the satisfaction of all parties. The FEMP protocol was developed in parallel with the International Performance Measurement and Verification Protocol, assuring consistency for companies doing business with both Federal agencies and private companies.

The FEMP guideline is based on three general approaches to assessing savings. The approaches, called Options A, B, and $\mathrm{C}$, are designed to cover the spectrum of project complexity. For many projects, savings may be verified with a minimum of measurement and at a minimum cost. Other projects call for a more rigorous approach to measurement and verification. In general, the more

Version 5.7

Dated: 04/19/00 rigorous the verification requirements, the more expensive the verification process will be.

Any efforts to perform annual $\mathrm{M} \& \mathrm{~V}$ will introduce additional costs that must be paid from resultant savings. A rule-of-thumb for estimating the cost of measurement and verification is that it will cost 3 to $10 \%$ of the project cost. Factors that affect measurement and verification costs include:

- Magnitude of savings

- Complexity of energy conservation measures

- Number of interactive energy conservation measures

- Risk allocation issues.

In those specific instances in which the savings are not significantly impacted by proper ongoing operations and maintenance, and for which savings can be accurately predicted (i.e., for lighting retrofits), detailed $M \& V$ may not add any significant value to the project. If the agency has concerns, however, that the technical measures to be accomplished are complex and/or are subject to degradation in future performance, this should be taken into account when determining overall project savings and whether annual M\&V should be included in the project.

The FEMP $M \& V$ Guideline is available at the FEMP web site listed later in this document.

\section{Step 6. Define the risks and benefits of the various scenarios}

The risks and benefits of the various options ultimately affect their costs. Every option carries with it risks and benefits. Examples of risks and benefits include:

- The agency realizes the benefits of improved reliability inherent in new equipment, assuming proper project execution.

- What is the risk associated with the technology performance? Interior lighting is an example of a lowrisk project - there is minimal maintenance required other than ensuring that high-efficiency ballasts and bulbs are used during routine maintenance. Mediumrisk projects would include HVAC upgrades because their performance is dependent on weather conditions and is more difficult to measure and verify. High-risk projects would include systems that are maintenance intensive (i.e., cogeneration) or technologies whose performance is not well proven.

- If the site is responsible for maintenance, will on-site mechanics maintain the new energy systems to retain the energy savings over the long-term? In a performance-based contract, if the site agrees to do maintenance, it is assuming part of the performance 
risk. In those cases, it is essential for the ESCO to provide training for Government personnel. The ESCO is also expected to monitor project performance to the extent necessary to identify performance shortfalls promptly.

- If using an ESPC, will the site be able to accurately measure and verify the contractor's energy savings to ensure that the ESCO is paid for actual energy savings? The benefit of accurate measurement and verification is that the site is certain that the systems are operating as planned and projected savings are being achieved.

- Alternative financing programs may allow you to execute projects without waiting for the budget process to allocate funds. This results in more timely project execution, with the associated savings being accrued to the Government.

The key to a successful project is to mitigate the risks while optimizing the benefits. If manpower or technical skills limit your ability to assimilate new technologies, then using an ESPC or Energy Services Agreement and having the ESCO or utility responsible for equipment O\&M may be the answer. If, on the other hand, you have adequate staffing and wish to retain responsibility for O\&M in-house, then the installing contractor (whichever financing option is selected) should provide training for your maintenance staff.

Project execution schedules may need to be customized to fit the needs of the tenants who occupy the buildings in which work is being performed. This is much easier to accommodate early in the project process than when the contractor is on-site and unable to start work because of scheduling conflicts.

In no case should a privately provided energy conservation services contract (either ESPC or UESC) include a power purchase component or restrictions or requirements on the provider of future sources of energy supply unless the acquisition team carefully studies the issue in detail and determines that such a decision is in the best interest of the government.

\section{Step 7. Select an energy project financing method}

Every day that a site delays a decision that will implement an energy savings project, the facility loses another day of energy cost savings. These lost savings are a reality, countable expense that will be paid from the site's utility or operations budget. The acquisition tem at the site must be mindful of this continuing expense as they proceed toward a decision of project financing. Excessive deliberation over the preferred financing option and conditions can

Version 5.7

Dated: 04/19/00 consume all of the cost savings that a site might hope to achieve through a very refined decision process. Acquisition teams should proceed quickly toward a decision on the preferred financing option.

The following pages outline an options matrix at a glance designed to assist you in determining which funding mechanisms are good options for energy projects at your site. Although scores have been assigned to many of the decision points (excellent, fair, or poor), each point should be evaluated for your individual site and those scores changed if necessary, or even eliminated as appropriate. Other topics can only be evaluated on a site-by-site basis, such as the availability of contracting mechanisms.

\section{Instructions for use of options matrix:}

1. Identify appropriate analysis factors for your site.

2. Add additional criteria as appropriate, or delete criteria that are not relevant to your site.

3. Assign site-specific weighting (excellent/average/poor) to those criteria factors. The weightings shown above are suggested values only, based on the rationale shown in the attached sheets. These values may need to be modified given your sitespecific conditions.

4. Identify the availability of the various funding mechanisms to your site.

5. Identify the degree of on-site support available. If onsite resources are not available, identify availability and cost of outside assistance.

Add the number of criteria in each category -excellent, average, and poor. This should only be done after you have assigned a weighting factor for each criteria being evaluated. With this information, you will able to identify options appropriate for your site, and compare those options.

\section{Conclusion}

There are multiple ways available to any site to analyze financing options; this paper outlines a single method. It is important when using any method that the site understands their project objectives and each financing option. Each financing option brings with it strengths and weaknesses that must be evaluated on a site-by-site basis. This is not a prescriptive procedure, and is intended to assist a site in identifying strengths and weakness of the various financing options.

\section{For Additional Information}

A great deal of up-to-date information about energy programs, technical support, and financing is available via the World Wide Web. A few of these sites are listed below: 
Department of Energy - Federal Energy Management Program

www.eren.doe.gov/femp

The Utility Incentives home page is at:

www.eren.doe.gov/femp/financing/utilincentives

The ESPC home page is at:

www.eren.doe.gov/femp/financing/espc.html

Measurement and verification guidelines are available at:

http://eande.lbl.gov/CBS/femp/MVdoc

General Services Administration - Energy Center of

Expertise

www.gsa.gov/pbs/centers/energy

A listing of GSA area-wide utility service contracts is available at:

WwW.gsa.gov/pbs/xu/contracts 1

Department of Energy -- Energy Information

Administration

$\underline{\text { www.eiainfo.eia.doe.gov }}$

\section{Edison Electric Institute}

www.eei.org

Provides a generic utility/government agreement for energy efficiency services and a listing of utility contacts.

\section{Acknowledgements}

This paper represents a collaborative effort of staff from both the Pacific Northwest National Laboratory (PNNL) and the National Renewable Energy Laboratory (NREL). PNNL is operated by the Battelle Memorial Institute, and NREL is operated by the Midwest Research Institute, Battelle Memorial Institute, and Bechtel National, Inc.

The following individuals provided extensive review and comments to earlier versions of this document:
Mr. Jim Woods, CEM, Energy Conservation Officer, Office of Real Estate Policy, U.S. Department of Commerce

Mr. Mark Ewing, General Services Administration Energy Center

Ms. Katherine McMordie-Stoughton, Pacific Northwest National Laboratory

Mr. Ronald Durfey, Energy Manager, U.S. Marine Corps Air Station Yuma, Arizona 


\section{Options Matrix: AT A GLANCE}

Excellent Average Poor
A
$\mathrm{C}$
$\mathrm{F}$

\begin{tabular}{|c|c|c|c|}
\hline & Agency & UESC & ESPC \\
\hline \multicolumn{4}{|l|}{ Objectives } \\
\hline \multicolumn{4}{|l|}{ Meet energy-efficiency goals } \\
\hline \multicolumn{4}{|l|}{ Reduce energy costs } \\
\hline \multicolumn{4}{|l|}{ Reduce maintenance costs } \\
\hline \multicolumn{4}{|l|}{ Improve reliability } \\
\hline \multicolumn{4}{|l|}{ Allow future changes in building use } \\
\hline \multicolumn{4}{|l|}{ Project development costs } \\
\hline \multicolumn{4}{|l|}{ Capital costs } \\
\hline \multicolumn{4}{|l|}{ Operations and maintenance } \\
\hline \multicolumn{4}{|l|}{ Post-project energy costs } \\
\hline \multicolumn{4}{|l|}{ Guaranteed energy and cost savings are desired } \\
\hline \multicolumn{4}{|l|}{ For the following elements, select only the line that applies to your site } \\
\hline \multicolumn{4}{|l|}{ Project urgency (select one) } \\
\hline \multicolumn{4}{|l|}{ Low (3 or more years) } \\
\hline \multicolumn{4}{|l|}{ Medium ( $>1$ year and $<3$ years) } \\
\hline \multicolumn{4}{|l|}{$\operatorname{High}(<1$ year $)$} \\
\hline \multicolumn{4}{|l|}{ Technology range of energy-efficiency measure opportunities (select one) } \\
\hline \multicolumn{4}{|l|}{ 1-2 “common" technologies (e.g., lighting and small motors) } \\
\hline \multicolumn{4}{|l|}{$\begin{array}{l}2 \text { or more state-of-the-shelf technologies (controls, variable speed drives } \\
\text { [VSD], boilers, chillers, renewables, inclusive of "standard" lighting retrofits) }\end{array}$} \\
\hline \multicolumn{4}{|l|}{ Specialized technologies } \\
\hline \multicolumn{4}{|l|}{ Electric utility deregulation status (select one) } \\
\hline \multicolumn{4}{|l|}{ Within 3 years } \\
\hline$>3$ years & & & \\
\hline
\end{tabular}




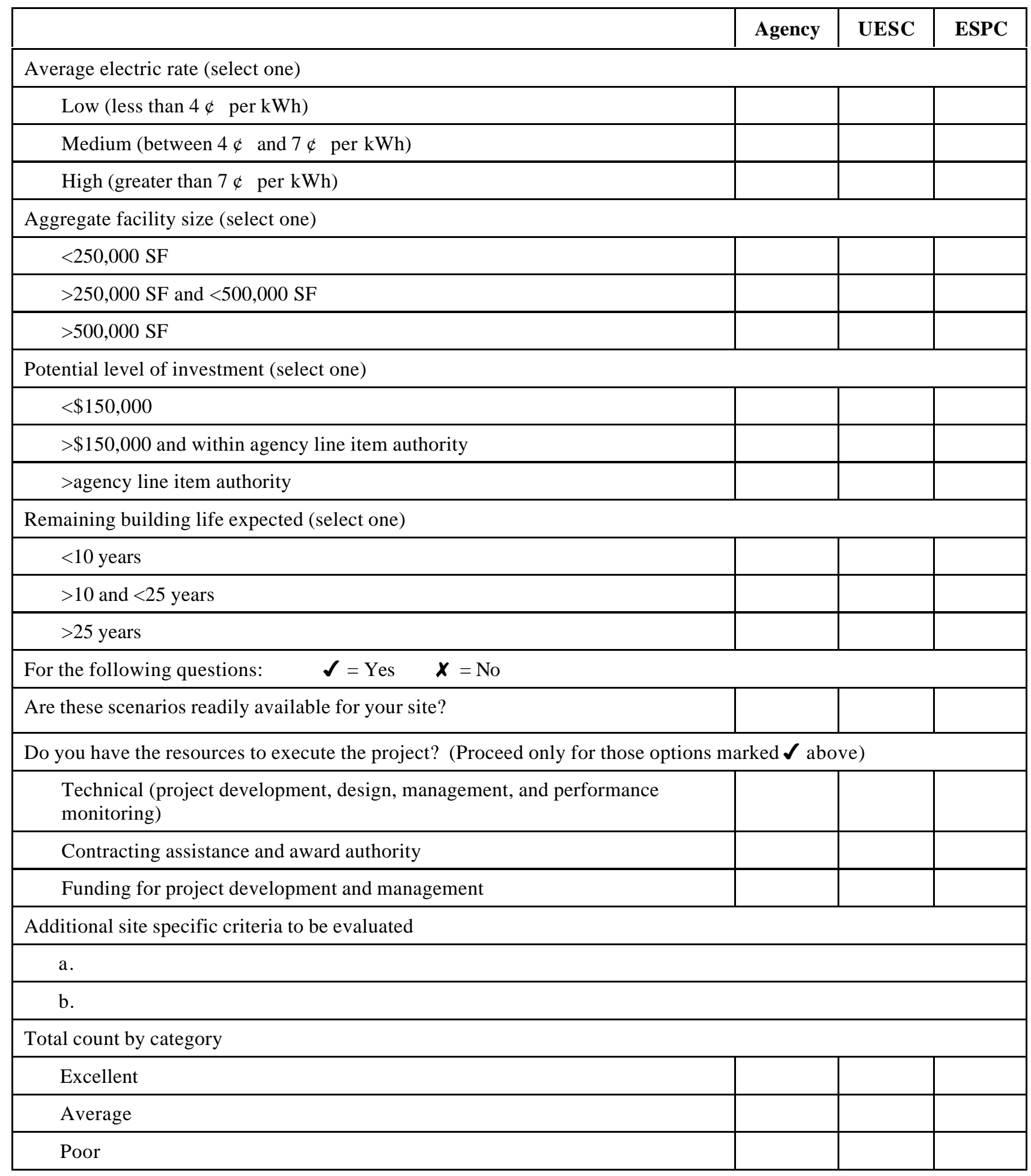




\begin{tabular}{|c|c|c|c|}
\hline \multicolumn{4}{|l|}{ Options Summary } \\
\hline & Agency & UESC & ESPC \\
\hline Authority & & $\begin{array}{l}\text { EPAct, } 42 \text { USC } 8256,10 \text { USC } 2865,48 \\
\text { CFR } 41,48 \text { CFR } 16\end{array}$ & EPAct, 42 USC 8287, 10 CFR 436 \\
\hline $\begin{array}{l}\text { Project development } \\
\text { requirements }\end{array}$ & $\begin{array}{l}\text { Project development and engineering } \\
\text { study } \\
\text { Architect/engineer design fees }\end{array}$ & $\begin{array}{l}\text { Project development and engineering study } \\
\text { Architect/engineer design fees } \\
\text { Negotiate utility contract modification } \\
\text { when applying utility project financing. In } \\
\text { some cases, whether financing is required } \\
\text { or not, requires only a simple delivery } \\
\text { order to be executed under the existing } \\
\text { utility contract. }\end{array}$ & $\begin{array}{l}\text { DOE Super ESPC - } \$ 10,000 \text { if no } \\
\text { DOE support required; } \$ 50,000 \text { for } \\
\text { Government-identified projects; } \\
\$ 30,000 \text { for ESCO-identified projects } \\
\text { where DOE support is required } \\
\text { Corps of Engineers ESPC - } 1 \% \text { of } \\
\text { annual energy bill (negotiable) } \\
\text { Memorandum of Understanding between } \\
\text { agency and DOE or Army COE }\end{array}$ \\
\hline $\begin{array}{l}\text { Capital cost (installed } \\
\text { equipment cost) }\end{array}$ & $\begin{array}{l}\text { Government pays } 100 \% \text { minus any utility } \\
\text { rebates }\end{array}$ & $\begin{array}{l}\text { Government and utility may cost-share } \\
\text { (rebate), or utility may provide financing to } \\
\text { be repaid by Government through utility } \\
\text { bills }\end{array}$ & $\begin{array}{l}\text { Energy services contractor (ESCO) pays } \\
100 \%\end{array}$ \\
\hline Contracting mechanism & $\begin{array}{l}\text { Open bid, or through existing facility } \\
\text { support contract }\end{array}$ & $\begin{array}{l}\text { Through the utility and assisted by site's } \\
\text { utility contracting officer. Contact site's } \\
\text { utility representative }\end{array}$ & $\begin{array}{l}\text { Open bid for site-specific, or } \\
\text { Existing Department of Energy Super } \\
\text { ESPC, or } \\
\text { Existing Army Corps of Engineers- } \\
\text { Huntsville ESPC }\end{array}$ \\
\hline Contract term & $\begin{array}{l}\text { Period of performance of the construction } \\
\text { contract as specified in the project }\end{array}$ & Up to 10 years & Up to 25 years \\
\hline Payment schedule & Progress payments & Included in utility bill & $\begin{array}{l}\text { Monthly with annual adjustment based } \\
\text { on performance verification }\end{array}$ \\
\hline Savings guarantee & None & $\begin{array}{l}\text { Not required, but may be negotiated into } \\
\text { the agreement }\end{array}$ & $\begin{array}{l}\text { Required by law. Savings must be } \\
\text { verified annually }\end{array}$ \\
\hline
\end{tabular}




\begin{tabular}{|c|c|c|c|}
\hline & Agency & UESC & ESPC \\
\hline $\begin{array}{l}\text { Post-award resource } \\
\text { requirements }\end{array}$ & $\begin{array}{l}\text { Contract management, inspection, } \\
\text { payments, and commissioning }\end{array}$ & $\begin{array}{l}\text { Contract management, inspection, } \\
\text { payments, and commissioning. Annual } \\
\text { measurement \& verification is not } \\
\text { specifically required, but may be } \\
\text { negotiated. However, the net overall } \\
\text { energy or water cost reduction should be } \\
\text { demonstrated and verified. }\end{array}$ & $\begin{array}{l}\text { Contract management, inspection, } \\
\text { payments, and commissioning } \\
\text { Measurement and verification of actual } \\
\text { savings }\end{array}$ \\
\hline $\begin{array}{l}\text { Operations and } \\
\text { maintenance } \\
\text { Routine operations, } \\
\text { Recurring preventive } \\
\text { maintenance, } \\
\text { Non-recurring corrective } \\
\text { maintenance }\end{array}$ & Government & $\begin{array}{l}\text { Government } \\
\text { Utility may share (negotiable) }\end{array}$ & $\begin{array}{l}\text { ESCO (Government may assume } \\
\text { responsibility for maintenance by } \\
\text { including provision in the delivery order) }\end{array}$ \\
\hline $\begin{array}{l}\text { Post-project energy } \\
\text { cost } \\
\text { Energy, } \\
\text { Demand, } \\
\text { Reactive power, } \\
\text { Meter charge, and } \\
\text { Standby fees }\end{array}$ & $\begin{array}{l}\text { Baseline minus project savings } \\
\text { (Government retains all savings) }\end{array}$ & $\begin{array}{l}\text { Baseline minus project savings, but may } \\
\text { need to add loan payments to utility }\end{array}$ & $\begin{array}{l}\text { Baseline energy cost minus guaranteed } \\
\text { energy savings plus payments to ESCO } \\
\text { (ESCO retains savings during period of } \\
\text { performance to recoup the capital and } \\
\text { operations costs) }\end{array}$ \\
\hline Net impact to the site & $\begin{array}{l}\text { Government finances total project cost, } \\
\text { keeps total savings, and is responsible for } \\
\text { operations and maintenance } \\
\text { Performance is dependent on proper } \\
\text { design, construction, commissioning, } \\
\text { operations and maintenance }\end{array}$ & $\begin{array}{l}\text { Utility cost-shares or finances project } \\
\text { capital cost } \\
\text { Government keeps savings, but may need } \\
\text { to repay loan to utility } \\
\text { Government is typically responsible for } \\
\text { O\&M } \\
\text { Performance is dependent on proper } \\
\text { design, construction, commissioning, and } \\
\text { O\&M }\end{array}$ & $\begin{array}{l}\text { ESCO finances total project cost, retains } \\
\text { portion of energy savings over the period } \\
\text { of the contract to recoup the investment. } \\
\text { Having the ESCO responsible for } \\
\text { operations and maintenance may impact } \\
\text { the Government's staffing or service } \\
\text { contracts. } \\
\text { Performance is guaranteed (ESCO } \\
\text { responsibility to verify savings annually) }\end{array}$ \\
\hline
\end{tabular}




\section{Appendix: Federal Site Example}

The following is a hypothetical example to illustrate the use of the options matrix. Modifications should be made to the matrix to apply it to a specific site and potential project. These modifications may include, new categories, a different weighting of the categories, and/or a more suitable scoring system (the example uses A-F).

Site Example: A military base located in the Northeast provides housing for military and civilians. An energy audit was performed on the entire facility, identifying numerous energy saving opportunities. The base was interested in reducing the large electricity bill paid each month. Consequently, two opportunities in lighting and one in peak shaving were bundled to reduce the energy and demand charges respectively. The peak shaving opportunity was added to improve the economics. Without peak shaving, the initial investment was approximately $\$ 3.64$ million, yielding a $\$ 705,000$ saving, and a 5-year payback. But with peak shaving, an investment of $\$ 3.93$ million yields a $\$ 1.27$ million saving, and a 3-year payback. Thus, the project included the following:

1. Upgrade fluorescent lighting

2. Change to high-pressure sodium (HPS) exterior lighting

3. Modify existing on-site generators for peak shaving

To determine the best method of funding for this project, the options matrix will be utilized and each criterion analyzed for this specific site.

\begin{tabular}{|l|c|c|c|}
\hline Objectives & Agency & UESC & ESPC \\
\hline Meet energy-efficiency goals & A & A & A \\
\hline Reduce energy costs & A & B & C \\
\hline Reduce maintenance costs & $\mathrm{C}$ & $\mathrm{C}$ & $\mathrm{C}$ \\
\hline Improve reliability & $\mathrm{B}$ & $\mathrm{B}$ & $\mathrm{B}$ \\
\hline Allow future changes in building use & $\mathrm{A}$ & $\mathrm{B}$ & $\mathrm{C}$ \\
\hline
\end{tabular}

\section{Meet energy-efficiency goals:}

Agency $=$ UESC $=$ ESPC $=$ "excellent" - All funding sources allow this objective to be met.

\section{Reduce energy costs:}

$>$ Agency $=$ "excellent" - Government funding means the base will be immediately realize $100 \%$ of the savings.

$>$ UESC = "good" - The utility offered to fund a significant portion of the engineering design costs that does not have to be paid back. The capital cost is financed, and must be repaid over the term of the contract, which is short than proposed under the ESPC.

$>\mathrm{ESPC}=$ "average" - The contract stipulates that $100 \%$ of all funds must be paid back commencing as soon as the savings are realized. The base does not get significant savings until after the contract has expired. If the ESCO is able to secure services from the utility through engineering services the grade would be higher. 


\section{Reduce maintenance costs:}

Agency $=$ UESC $=$ ESPC $=$ "good" - The longer lamp lives, and parts standardization will save some labor and administration costs. However, the existing generators that were for back up only, will now operate during peak demand times, and are expected to require additional maintenance.

\section{Improve reliability:}

$>$ Agency $=\mathrm{UESC}=\mathrm{ESPC}=$ "good" - The new equipment is expected to improve reliability. Moreover, the modified generators provide a power source that can feed the electrical distribution system in an emergency, enhancing the overall dependability of the base power infrastructure.

\section{Allow future changes in building use:}

$>$ Agency $=$ " excellent" - Government funding means that no resources are tied up in long term contracts.

$>$ UESC $=$ "good" - The utility is sharing a portion of the engineering design costs.

$>$ ESPC $=$ "average" - The ESPC will pay $100 \%$ of all up front costs. Therefore, the base will be obligated to pay back the loan for the life of the contract.

\section{Project Development Costs}

\begin{tabular}{|c|c|c|}
\hline Agency & UESC & ESPC \\
\hline C & B & D \\
\hline
\end{tabular}

Agency = "average" - The initial energy audit provided most of the engineering design work for the project, which facilitates keeping the project development costs down. In addition, the lighting portion of the project involves common technology. However, the peak shaving portion of the project is not straightforward and will require design modifications to the generators and a control system. The agency would have to contract most of this work out.

$>$ UESC = "good" - The utility, being familiar with the site, could provide some services at moderate costs to the project.

$>\mathrm{ESPC}=$ " poor" - Activities may require a limited competition among qualified ESPC contractors. Their personnel are unfamiliar with the base. Thus, their support involves a learning curve and adds considerable costs to the project. Services provided through the FEMP Service Network would cost $\$ 30,000$. Services provided by the COE, would be a negotiable fee based on the size of the project.

\begin{tabular}{|l|c|c|c|}
\hline \multirow{2}{*}{ Capital Costs } & Agency & UESC & ESPC \\
\cline { 2 - 5 } & F & B & A \\
\hline
\end{tabular}

$>$ Agency $=$ "poor" - The government would have to pay $100 \%$ of the project funding.

$>\mathrm{UESC}=$ "good" - The utility has offered to pay a portion of the engineering design costs. The agency will be required to perform some services. 
ESPC $=$ "excellent" - The ESPC will pay 100\% of all up-front capital costs.

Operation and Maintenance costs

\begin{tabular}{|c|c|c|}
\hline Agency & UESC & ESPC \\
\hline $\mathrm{F}$ & $\mathrm{B}$ & $\mathrm{B}$ \\
\hline
\end{tabular}

Agency = "poor" - Lighting is common technology, however, the strategy and implementation of demand peak shaving with generators is more complicated. The base would have to contract it out, at high cost.

UESC $=$ ESPC $=$ "good" - Utilities and ESCOs have expertise in peak shaving systems. They would be able to include in the contract at a moderate cost, the O\&M of the equipment, reducing the risk to the base.

\section{Post-project costs}

\begin{tabular}{|c|c|c|}
\hline Agency & UESC & ESPC \\
\hline A & B & C \\
\hline
\end{tabular}

Agency = "excellent" - The base will realize $100 \%$ of the energy savings from the project immediately. The base will not perform a measurement and verification $(\mathrm{M} \& \mathrm{~V})$ activity, thus no additional costs.

$>\mathrm{UESC}=$ "good" - No measurement and verification $(\mathrm{M} \& \mathrm{~V})$ activity was requested, but capital cost of the installed equipment must be repaid.

$>\mathrm{ESPC}=$ "average" - The savings measurement and verification $(\mathrm{M} \& \mathrm{~V})$ activities are part of the post project activities and have been included as part of the overall project cost.

\section{Guaranteed energy and cost savings desired}

\begin{tabular}{|c|c|c|}
\hline Agency & UESC & ESPC \\
\hline F & F & A \\
\hline
\end{tabular}

$>$ Agency = "poor" - The base, or any contractor hired by the base, will not guarantee the savings.

$>\mathrm{UESC}=$ "poor" - The utility will not guarantee the savings.

$>\mathrm{ESPC}=$ "excellent" - The ESPC requires a guaranteed energy savings. 


\begin{tabular}{|l|c|c|c|}
\hline Project Urgency & Agency & UESC & ESPC \\
\hline Low $(3$ or more years $)$ & $\mathrm{C}$ & $\mathrm{A}$ & $\mathrm{A}$ \\
\hline Medium $(>1$ year and $<3$ years $)$ & & & \\
\hline High $(<1$ year $)$ & & & \\
\hline
\end{tabular}

$>$ Agency $=$ "good" - Lighting and the generators are existing and operational. The primary objective of the project is to save energy, not to meet a more critical need, such as safety, or equipment failure.

Therefore, the project will be prioritized and funded, based on the return on investment.

$>\mathrm{UESC}=\mathrm{ESPC}=$ "excellent" - Utility and the ESPC programs are structured to fund energy saving projects in this time frame.

\begin{tabular}{|l|c|c|c|}
\hline Technology range of energy-efficiency measure opportunities & Agency & UESC & ESPC \\
\hline 1-2 "common" technologies (e.g., lighting and small motors) & A & A & A \\
\hline $\begin{array}{l}\text { 2 or more state-of-the-shelf technologies (controls, variable speed drives } \\
\text { [VSD], boilers, chillers, renewables, inclusive of "standard" lighting retrofits) }\end{array}$ & & & \\
\hline Specialized technologies & F & A & A \\
\hline
\end{tabular}

\section{Technology-Common technology (lighting):}

$>$ Agency $=$ UESC $=$ ESPC $=$ “excellent" - Lighting is fairly easy to install and a proven technology that ensures expected results.

\section{Technology-Specialized technology (generators):}

Agency = "poor" - Peak shaving systems are complicated and difficult for the base to execute properly.

UESC = ESPC = "excellent" - The Utility and the ESCO have the expertise to efficiently implement a complicated project involving peak shaving controls and generator modifications.

\begin{tabular}{|l|c|c|c|}
\hline Electric utility deregulation status & Agency & UESC & ESPC \\
\hline Within 3 years & A & B & C \\
\hline$>3$ years & & & \\
\hline
\end{tabular}

Agency = "excellent" - Government funding enables the base to avoid volatile contractual environments.

$>\mathrm{UESC}=$ "Good" - The utility is paying a portion of the cost and is willing to reduce their payments based on the current price rate to avoid a volatile contractual environments. 
$>\mathrm{ESPC}=$ "average" - Electrical rates may drop within the next couple of years. Thus, if the base does get into a 6-year contract ${ }^{\mathrm{a}}$, they would still be requires to reimburse the ESCO at the rates established in the contract.

\begin{tabular}{|l|c|c|c|}
\hline Average electric rate & Agency & UESC & ESPC \\
\hline Low (less than $4 \varnothing$ per $\mathrm{kWh})$ & & & \\
\hline Medium (between $4 \varnothing$ and $7 \phi$ per $\mathrm{kWh}$ ) & B & B & B \\
\hline High (greater than $7 \varnothing$ per $\mathrm{kWh})$ & & & \\
\hline
\end{tabular}

\section{Average electric rate:}

$>$ Agency $=\mathrm{UESC}=\mathrm{ESPC}=$ "good" - The average electric rate of $\$ 0.05 / \mathrm{kWh}$ is in the medium range. This unit cost coupled with a substantial $\mathrm{kWh}$ load, results in a high annual energy cost. ${ }^{\mathrm{b}}$ The high cost of energy makes the project life-cycle cost effective.

\begin{tabular}{|l|c|c|c|}
\hline Aggregate facility size & Agency & UESC & ESPC \\
\hline$<250,000 \mathrm{SF}$ & & & \\
\hline$>250,000 \mathrm{SF}$ and $<500,000 \mathrm{SF}$ & & & \\
\hline$>500,000 \mathrm{SF}$ & $\mathrm{A}$ & $\mathrm{A}$ & $\mathrm{A}$ \\
\hline
\end{tabular}

Agency $=$ UESC $=$ ESPC $=$ "excellent" - This project involves numerous buildings with over 6,400,000 square feet of space to illuminate. The average electric rate of $\$ 0.05 / \mathrm{kWh}$ combined with this significant electrical demand generates sufficient potential savings that is attractive to all the funding sources.

\begin{tabular}{|l|c|c|c|}
\hline Potential level of investment & Agency & UESC & ESPC \\
\hline$<\$ 150,000$ & & & \\
\hline$>\$ 150,000$ and within agency line item authority & & & \\
\hline$>$ agency discretionary authority & $\mathrm{C}$ & $\mathrm{A}$ & $\mathrm{A}$ \\
\hline
\end{tabular}

$>$ Agency $=$ " good" - Although the project generates a good return, the investment level is above the "agency line item authority" which would delay the approval process.

$>\mathrm{UESC}=\mathrm{ESPC}=$ "excellent" - The project has a good payback and represents approximately $16 \%$ energy savings. ${ }^{\mathrm{c}}$ A good project to be funded by a UESC or an ESPC.

\footnotetext{
${ }^{\mathrm{a}}$ Contract term $=2 *$ Capital investment /annual savings $=2 *(\$ 3,930,000 / \$ 1,270,000)=6$ years

${ }^{\mathrm{b}}$ Annual energy cost $=\$ 50 / \mathrm{Mwh}^{*} 90,392 \mathrm{mWh} /$ year $=\$ 4,519,600 /$ year $16 \%$
} 


\begin{tabular}{|l|c|c|c|}
\hline Remaining building life expected & Agency & UESC & ESPC \\
\hline$<10$ years & & & \\
\hline$>10$ and $<25$ years & & & \\
\hline$>25$ years & A & A & A \\
\hline
\end{tabular}

Agency $=$ UESC $=$ ESPC $=$ "excellent" - Most of the building involved in the project are fairly new and are expected to remain in service for at least 10 years. The longest contract is expected to be 6 years; thus, any of the funding sources would suit the project.

\section{Are these scenarios readily available for your site?}

\begin{tabular}{|c|c|c|}
\hline Agency & UESC & ESPC \\
\hline$\checkmark$ & $\checkmark$ & $\checkmark$ \\
\hline
\end{tabular}

$>$ Agency $=$ "Yes" - The site has funding available

$>\mathrm{UESC}=$ "Yes" - The utility has a design assistance program and/or is willing to participate in $3^{\text {rd }}$ party financing

$>\mathrm{ESPC}=$ "Yes" - There is an ESPC available in this region.

\begin{tabular}{|l|c|c|c|}
\hline Do you have the resources to execute the project? & Agency & UESC & ESPC \\
\hline $\begin{array}{l}\text { Technical (project development, design, management, and performance } \\
\text { monitoring) }\end{array}$ & $\checkmark$ & $\checkmark$ & $\checkmark$ \\
\hline Contracting assistance and award authority & $\checkmark$ & $\checkmark$ & $\checkmark$ \\
\hline Funding for project development and management & $\checkmark$ & $\checkmark$ & $\checkmark$ \\
\hline
\end{tabular}

Technical:

$>$ Agency $=$ "Yes" - The base has engineering staff available to revise and/or review layout and design drawings as necessary, specify and procure equipment, provide scope and estimates, schedule contractors and monitor their performance and manage the overall project for the base.

$>\mathrm{UESC}=$ "Yes" -The base has engineering staff available to work with the utility on specifying and procuring equipment, revise and/or review layout and design drawings as necessary, provide scope and estimates, schedule contractors and monitor their performance and manage the overall project for the base.

$>E S P C=$ "Yes" - The base has engineering staff available to review drawings, specifications, procurement and scheduling plans. In addition, the base can provide personnel to manage the progress of the ESCO for the base.

\section{Contracting assistance:}

$>$ Agency $=$ "Yes" - The base has a contracting officer that has the authority to sign contracts. 
$>\mathrm{UESC}=$ "Yes" - The base has a qualified contracting officer that can administer utility contracts. Moreover, the base representative has the authority to sign contracts.

$>$ ESPC $=$ "Yes" - The base has a qualified contracting officer that has experience with and can administer performance contracts. Moreover, the officer has the authority to sign contracts.

\section{Funding:}

$>$ Agency $=$ "Yes" - The base has the funds to support the engineering, procurement and management tasks associated with the project, including any outside engineering design work that needs to be done on the peak shaving portion of the project.

$>\mathrm{UESC}=\mathrm{ESPC}=$ "Yes" - The funding to develop the project can be included in the UESC and ESPC.

\begin{tabular}{|l|c|c|c|}
\hline Total count of categories: & Agency & UESC & ESPC \\
\hline Excellent A & 0 & 8 & 9 \\
\hline Good B & & & \\
\hline Average C & 5 & 10 & 4 \\
\hline Poor D & 4 & 0 & 5 \\
\hline
\end{tabular}

\section{Total count of categories:}

By counting up the criteria, the funding alternative that is appropriate for this project, at this base, can be determined. In this case each criterion was equally weighted. However, because of the unique circumstances, the energy manager may not want the criteria equally weighted. In addition, because the answers given above such as "No agency funding is available for energy conservation projects at this time", one or more of the options may be ruled out, and the funding decision would have to be reevaluated to find another solution. 
PNNL-13140

\section{Distribution}

No. of

Copies

OFFSITE

2 Bonneville Power Administration Seattle Customer Service Cntr-PNF 1601 Fifth Avenue, Suite 1000

Seattle, WA 98101-1670

Attn: Frank E. Brown

15 Brookhaven National Laboratory

Building 134C

Upton, Long Island, NY 11973

Attn: Mark P. Toscano

Lawrence Berkeley National Laboratory

Building Technologies Department,

Team A

1250 Maryland Ave, S.W. \#500

Washington, DC 20024

Attn: Camelia Ilarslan

Lawrence Berkeley National Laboratory

Building Technologies Department,

Applications Team

1250 Maryland Ave, S.W. \#500

Washington, DC 20024

Attn: Charles H. Williams

National Renewable Energy Laboratory 1617 Cole Blvd.

Golden, CO 80401-3393

Attn: Doug Dahle

Oak Ridge National Laboratory

PO Box 2008

Building 3147

Oak Ridge, TN 37831-6070

Attn: Patrick Hughes

U.S. Department of Energy

1000 Independence Avenue, SW

Washington, DC 20585

Attn: B. Gustafson, EE-92, Room 6B-

052

U.S. Department of Energy

1000 Independence Avenue, SW

Washington, DC 20585

Attn: T. Muessel, EE-92, Room 6B-

052
No. of

Copies

2 U.S. Department of Energy

1000 Independence Avenue, SW

Washington, DC 20585

Attn: V. Petrolati, EE-92, Room 6B-

052

U.S. Department of Energy

1000 Independence Avenue, SW

Washington, DC 20585

Attn: W. Prue, EE-92, Room 6B-052

U.S. Department of Energy

Atlanta Regional Support Office

730 Peachtree Street, NE, Suite 876

Atlanta, GA 30308

Attn: Doug Culbreth

U.S. Department of Energy

Boston Regional Office

JFK Federal Building, Rm 675

Boston, MA 02203

Attn: Paul King

U.S. Department of Energy

Chicago Regional Support Office

1 South Wacker Drive, Suite 2380

Chicago, IL 60606

Attn: Sharon Gill

U.S. Department of Energy

Denver Regional Office

1617 Cole Blvd.

Golden, CO 80401

Attn: Randy Jones

U.S. Department of Energy

Philadelphia Regional Support Office

1880 JFK Blvd., Suite 501

Philadelphia, PA 19102

Attn: Bill Klebous

U.S. Department of Energy

Seattle Regional Support Office

800 Fifth Avenue, Suite 3950

Seattle, WA 98104

Attn: Cheri Sayer 
No. of

Copies

\section{ONSITE}

J. Hail (2) P7-63

D. Hunt (35) BWO

S. Parker K5-08

W. Sandusky (2) K5-08

G. Sullivan K8-07

Information Release (7) K1-06 